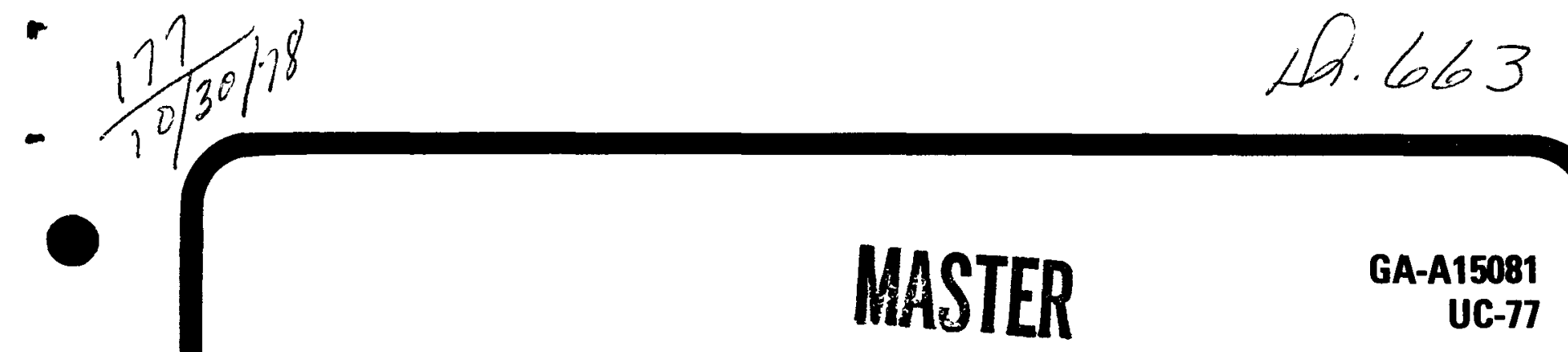

\title{
THE GENERAL ATOMIC HTGR FUEL REPROCESSING PILOT PLANT: RESULTS OF INITIAL SEQUENTIAL EQUIPMENT OPERATION
}

\section{by \\ PROJECT STAFE}

\author{
Prepared under \\ Contract EY-76-C-03-0167 \\ Project Agreement No. 53 \\ for the San Francisco Operations Office \\ Department of Energy
}

DATE PUBLISHED: SEPTEMBER 1978

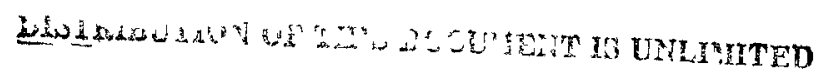

\section{GENERAL ATOMIC COMPANY}




\section{NOTICE}

This report was prepared as an account of work sponsored by the United States Government. Neither the United States nor the Department of Energy, nor any of their employees, nor any of their contractors, subcontractors, or their employees, makes any warranty, express or implied, or assumes any legal hability or responsibility for the accuracy, completeness or usefulness of any information, apparatus, product or process disclosed, or represents that its use would not infringe privately owned rights

Printed in the United States of America Available from

National Technical Information Service

U.S. Department of Commerce 5285 Port Royal Road

Springfield, Virginia 22161

Price: Printed Copy $\$ 6.00$; Microfiche $\$ 3.00$ 


\section{DISCLAIMER}

This report was prepared as an account of work sponsored by an agency of the United States Government. Neither the United States Government nor any agency Thereof, nor any of their employees, makes any warranty, express or implied, or assumes any legal liability or responsibility for the accuracy, completeness, or usefulness of any information, apparatus, product, or process disclosed, or represents that its use would not infringe privately owned rights. Reference herein to any specific commercial product, process, or service by trade name, trademark, manufacturer, or otherwise does not necessarily constitute or imply its endorsement, recommendation, or favoring by the United States Government or any agency thereof. The views and opinions of authors expressed herein do not necessarily state or reflect those of the United States Government or any agency thereof. 


\section{DISCLAIMER}

Portions of this document may be illegible in electronic image products. Images are produced from the best available original document. 


\section{GA-A15081 \\ UC-77}

\section{THE GENERAL ATOMIC HTGR FUEL REPROCESSING PILOT PLANT: RESULTS OF INITIAL SEOUENTIAL EQUIPMENT OPERATION}

by

PROJECT STAFF

Prepared under

Contract EY-76-C-03-0167

Project Agreement No. 53

for the San Francisco Operations Office

Department of Energy

GENERAL ATOMIC PROJECT 3261

DATE PUBLISHED: SEPTEMBER 1978

\section{GENERAL ATOMIC COMPANY}




\section{ABSTRACT}

In September 1977, General Atomic Company completed the processing of 20 large high-temperature gas-cooled reactor (LHTGR) fuel elements sequentially through the head-end cold pilot plant equipment. This report gives a brief description of the equipment and summarizes the results of the sequential operation of the pilot-plant. 
$\sim$

$\bullet$

$\bullet$ 
CONTENTS

ABSTRACT . . . . . . . . . . . . . . . . . . . . . iii

1. INTRODUCTION . . . . . . . . . . . . . . . . . . . . 1

2. HEAD-END REPROCESSING FLOW SHEET . . . . . . . . . . . . . . . . 8

3. EQUIPMENT DESCRIPTIONS AND SUMMARY OF QUALIFICATION TESTING • • 11

3.1. Fuel Element Size Reduction . . . . . . . . . . . . . 11

3.2. Primary Burner .. . . . . . . . . . . . . . 11

3.3. Classifier, Particle Crusher, and Secondary Burner . . . 14

3.4. Solids Handling . . . . . . . . . . . . . . . 18

3.4.1. Component Testing . . . . . . . . . . . . . 22

3.4.2. Conveying Tests . . . . . . . . . . . . . 24

3.4.3. Samplers . . . . . . . . . . . . . 25

3.4.4. Flow Property Measurement . . . . . . . . 25

4. FEED MATERtal . . . . . . . . . . . . . . . . . 26

5. SAMPLING, PRELIMINARY TESTS AND PlANS . . . . . . . . . . . . 27

6. RESULTS OF INITIAL SEQUENTIAL OPERATION . . . . . . . . . . . . 30

6.1. UNIFRAME Operations . . . . . . . . . . . . . . . . 30

6.2. Primary Burning Operations . . . . . . . . . . . . 38

6.3. Fue1 Particle Air Classification Operations . . . . . . 66

6.3.1. Initial Bed Removal .............. 67

6.3.2. Plenum Materials . . . . . . . . . . . 69

6.3.3. Final Bed Removal Material ... . . . . . . 69

6.3.4. Classified Product Summation .......... 69

6.3.5. Discussion .............. . 70

6.3.6. Material Balances .............. 71

6.4. Fue1 Particle Crushing and Secondary Burning Operations • 71

6.4.1. Burning Operations . . . . . . . . . . . . . . 71

6.4.2. Product Material . . . . . . . . . . . . 78

6.4.3. Secondary Burner Removal System . . . . . . . . 78 
7. RESULTS ........................ 80

7.1. Overall Material Mass Balance . . . . . . . . . . . 80

7.2. Overal1 Particle Breakage and Crossover . . . . . . . . 86

REFERENCES . . . . . . . . . . . . . . . . . . . . . . . 91

FIGURES

1. HTGR fuel element . . . . . . . . . . . . . . . 2

2. HTGR coated fuel particles . . . . . . . . . . . . . . 3

3. Plant arrangement . . . . . . . . . . . . . . 5

4. Cold head-end layout . . . . . . . . . . . . . . . 9

5. UNIFRAME machine frame . . . . . . . . . . . . . . 12

6. UNIFRAME ventilation enclosure . . . . . . . . . . . 13

7. 40-cm primary burner configuration ............. 15

8. 20-cm primary burner configuration . . . . . . . . . . . 20

9. Data acquisition and processing block diagram . . . . . . . . 21

10. Typical bunker assembly . . . . . . . . . . . . . . . 23

11. Particle size distributions before and after transport . . . . 32

12. Comparison of particle size distributions between individual and average crosscut samples of crushed fuel elements . . . . 35

13. Observed versus predicted pressure drops for various systems . 39

14. Material size distribution, 40-cm primary burner . . . . . . 41

15. Detail of penetration through the upper cooling shroud . . . 43

16. Overall view of 40-cm primary burner for Runs D and E. . . . 44

17. Thermowell wall section . . . . . . . . . . . . . 48

18. Thermowell damage, meta11urgical evidence . . . . . . . . 49

19. System temperature for 40-cm primary burner, Run E, Sept. 13 . . . . . . . . . . . . . . . . . . 51

20. System temperature for 40-cm primary burner, Run $E$, Sept. 20 . . . . . . . . . . . . . . . . 52

21. Bed, filter, and cyclone pressure drops $(\Delta \mathrm{P})$ for $40-\mathrm{cm}$ primary burner, Run E, Sept. 20 . . . . . . . . . . 54

22. Cooling air flow, 40-cm primary burner, Run E, Sept. 13... . 56

23. Cooling air flow, 40-cm primary burner, Run E, Sept. 20 . . . 57

24. Off-gas concentration for 40-cm primary burner, Run $E$, Sept. 13 . . . . . . . . . . . . . . . . . . . . 
FIGURES (Continued)

25. Off-gas concentration for 40-cm primary burner, Run E,

Sept. 20 . . . . . . . . . . . . . . . . .

26. Recycling fines oxide/hull content and fines sample history

for 40-cm primary burner, Run E. . . . . . . . . . . . 64

27. 20-cm secondary burner, size distribution of feed and product from sequential operation run . . . . . . . . . . . . 73

28. 20-cm secondary burner, sequential run, burner temperatures . . 74

29. 20-cm secondary burner, sequential run, $\mathrm{O}_{2}$ and $\mathrm{CO}_{2}$ gas flows . 75

30. 20-cm secondary burner, sequential run, cooling air flows . . 76

31. 20-cm secondary burner, sequential run, gas concentrations . . 77

32. Flow diagram . . . . . . . . . . . . . . . . . 83

TABLES

1. Operating guidelines summary, primary fluidized bed burner . . 16

2. Primary burner major control functions . . . . . . . . . . 17

3. Cumulative particle breakage from UNIFRAME and transport

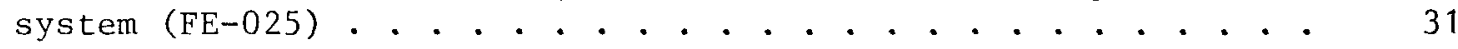

4. Cumulative particle breakage from UNIFRAME and transport system at velocities of $18 \mathrm{~m} / \mathrm{s}$ and $25 \mathrm{~m} / \mathrm{s}$. . . . . . . . . . . . 33

5. Cumulative particle breakage from UNIFRAME and transport system (sequential elements) ............. 36

6. Fuel element size reduction for sequential pilot plant operations . . . . . . . . . . . . . . . . 37

7. Material balance summary for $40-\mathrm{cm}$ primary burner test . . . 61

8. Particle breakage distribution based upon uranium, thorium analysis, 40-cm run................. . . . . 62

9. Particle breakage in primary burner product, before and after transport................... . . . 65

10. Classifier sequential tests . . . . . . . . . . . . 68

11. Material balance air classifier sequential tests . . . . . . 72

12. Fines analysis . . . . . . . . . . . . . . . . . 81

13. Chemical analysis on products after classification . . . . . 85

14. Material balance totals . . . . . . . . . . . . . . 87

15. Overall particle breakage and crossover . . . . . . . . . 88 


\section{INTRODUCTION}

The fuel for a high-temperature gas-cooled reactor (HTGR) consists of small coated particles embedded in fuel elements made from graphite, which acts as a neutron moderator (Fig. 1). The reactor utilizes thorium by converting it to U-233. Thorium can be incorporated into the fuel in a number of ways. To optimize the thorium-uranium fuel cycle, a system of separate fuel particles has evolved (Ref. 1). The two types of particles used are characterized by the coatings applied to them (Fig, 2): BIso particles are coated with a relatively porous buffer layer of carbon, and then with a dense coating of pyrolytic carbon; TRISO coatings have a silicon carbide ( $\mathrm{SiC}$ ) coating placed between two layers of pyrolytic carbon. The SiC layer provides a means of separating the TRISO particles from the BISO particles in head-end reprocessing operations, and it enhances fission product retention in the fissile particles. BISO coatings are used for particles which are initially loaded only with thorium oxide; TRISO coatings are used for particles loaded with uranium. After irradiation, the BISO fertile particles contain quantities of U-233. Separation of the fertile particles from the fissile TRISO particles and subsequent recovery of the bred U-233 for use in refabricated fuel is an indispensable part of the recycle of HTGR fuel. The development and demonstration of this recycle technology is the goal of the Department of Energy (DOE) funded National HTGR Fuel Recycle Development Program.

In June 1976, General Atomic Company (GA) completed the construction of a cold engineering-scale head-end pilot plant (Fig. 3). The purpose of the plant is to demonstrate the feasibility of the technology on an acceptable scale. In coming years, it will evolve into a cold prototype. In the 15 months since its completion, each system within the head-end pilot plant has been used for design verification experiments (or qualification testing) in a sequential operation of the entire pilot plant. 


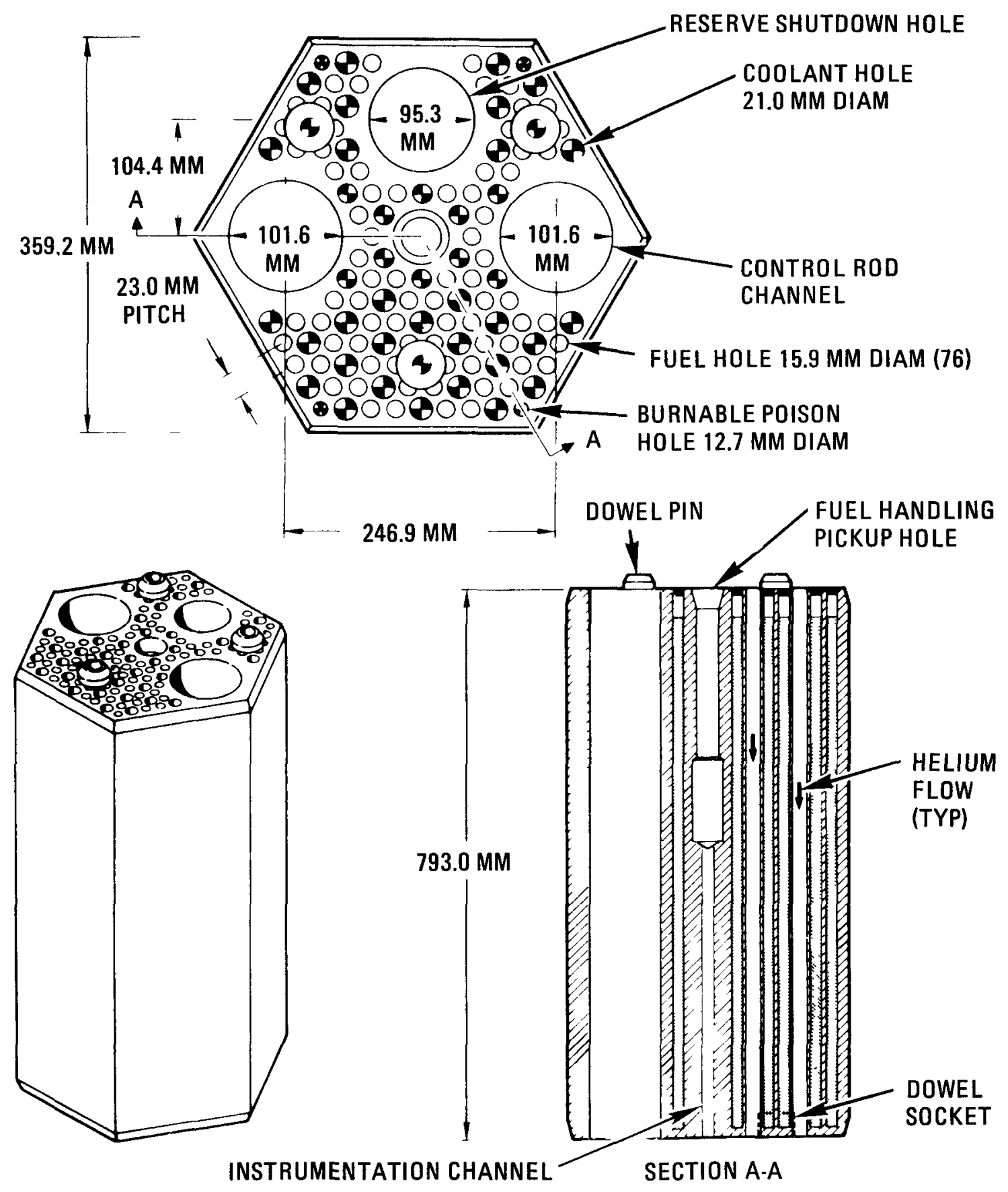

Fig. 1. HTGR fuel element 


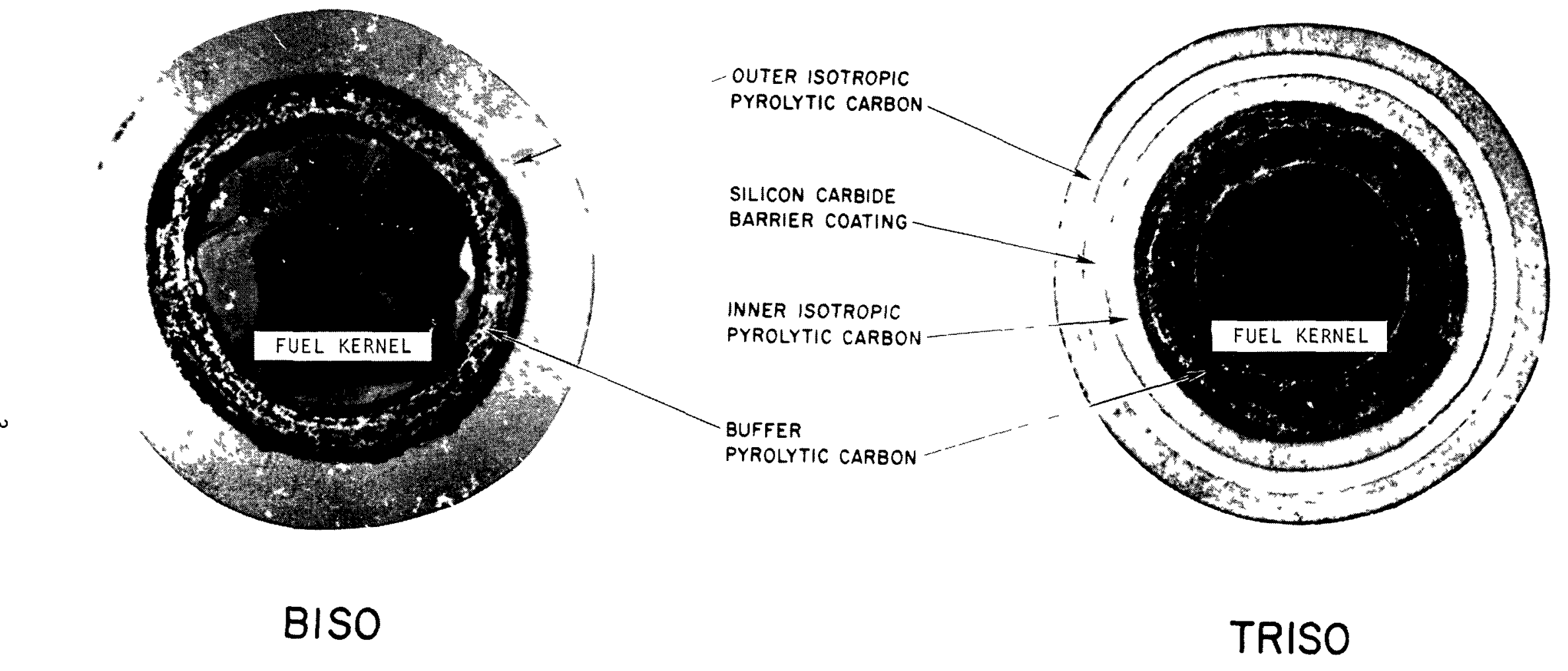

Fig. 2. HTGR coated fuel particles 
.

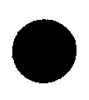

- 


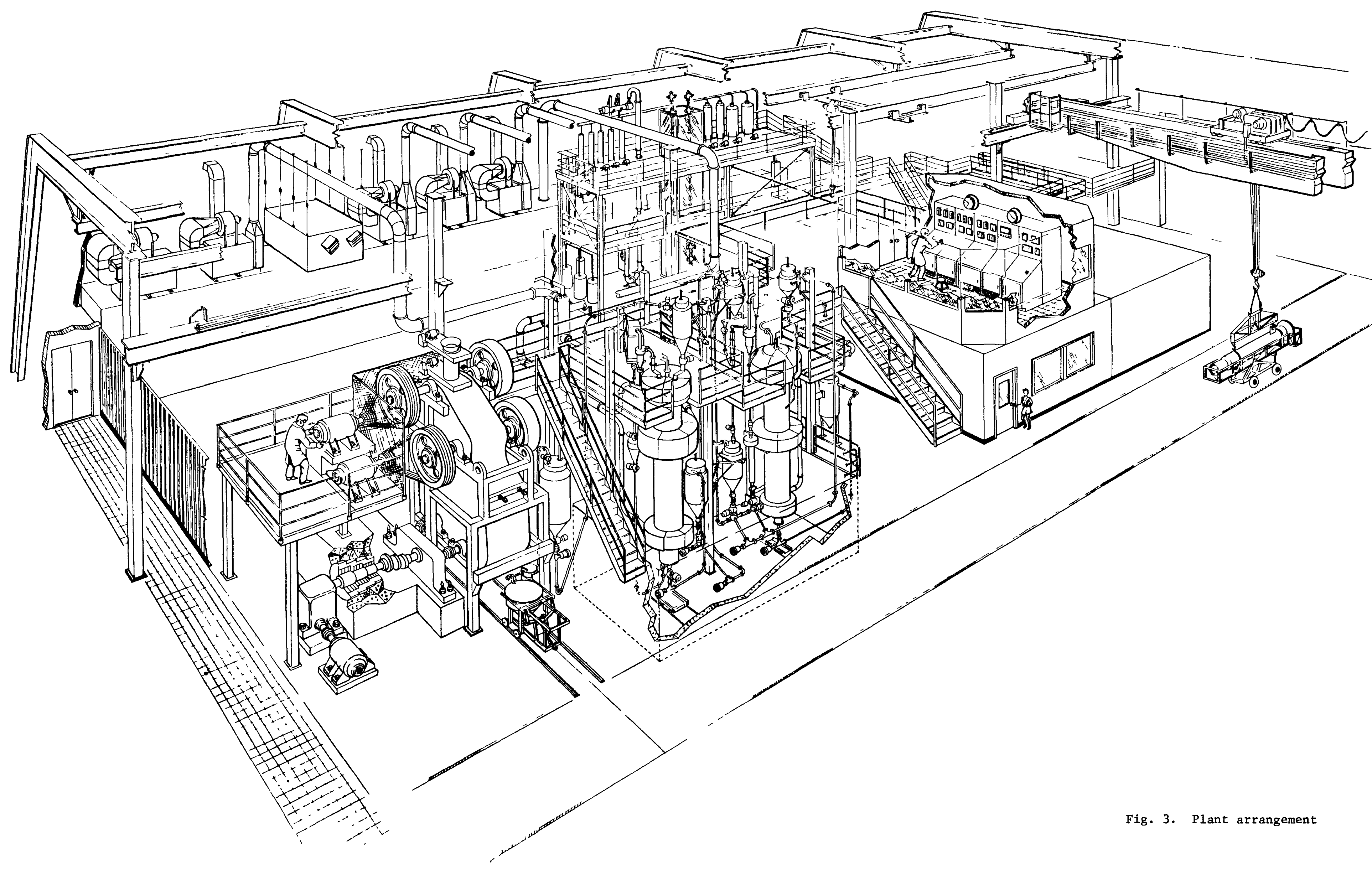


-

$\bullet$

$\bullet$ 
A summary of the results of qualification testing is given in Ref. 2 . This report gives a brief description of the equipment and summarizes the results of the sequential operation of the entire pilot plant. 


\section{HEAD-END REPROCESSING FLOW SHEET}

The purpose of the dry head-end of the reprocessing flow sheet is to prepare fuel particles for dissolution and solvent extraction. It comprises fuel element size reduction, crushed fuel element burning, particle classification, particle crushing, and crushed particle burning (Ref. 1). Unit operations are connected by the solids handling system (Fig. 4).

Fuel elements are reduced to $-4750-\mu \mathrm{m}$ fragments in a series of crushers (two overhead eccentric jaw crushers and one double-roll crusher), which are mounted in one frame; this system is designated the UNIFRAME. After screening, the crushed material is pneumatically conveyed to a product bunker and then to the feed bunker of the fluidized-bed crushed fuel element burner (or primary burner). The primary burner fluidizes crushed fuel elements with carbon dioxide and heats the initial charge with an induction heater. Oxygen is introduced to begin combustion, and cooling gas removes the heat of combustion through the burner wall. The fluidized bed temperature is maintained at around $900^{\circ} \mathrm{C}$. Fine particles are entrained by the fluidized gas and recycled to the bed after separation from the gas; fresh feed is continuously added to the burner. The graphite and outer carbon coatings are burned off, and the product is conveyed to the primary burner product bunker. The burner operates on a semicontinuous basis, i.e., only a part of the bed is dumped at any one time, until the end of an operating campaign. If the product is within spectfication, it is transferred to the pneumatic classifier feed bunker; if it contains excess carbon or graphite, it can be recycled to the primary burner feed bunker. The burned-back fuel particles are fed into a moving air stream within a zigzag classification column.

The light TRISO fissile particles are carried out of the top of the classifier, and the dense BISO fertile particles, which are $\mathrm{ThO}_{2}$, fall 


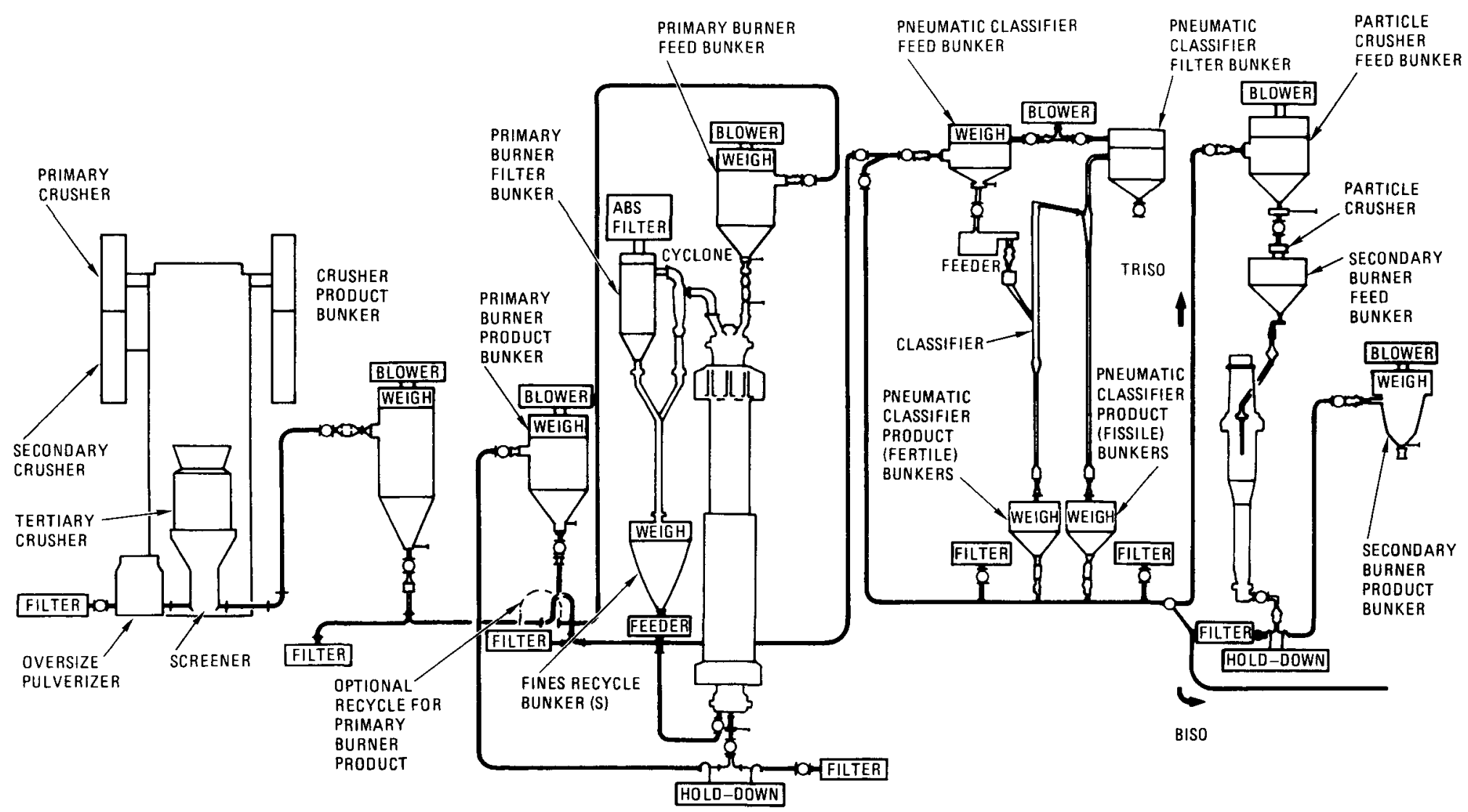

Fig. 4. Cold head-end layout 
out of the bottom, ready for dissolution and solvent extraction. In the event of unsatisfactory separation, particles from either or both classifier product bunkers can be recycled for reclassification.

The burned-back TRISO particles still contain inner carbon coatings which must be burned. They are conveyed to a particle crusher (where they are crushed), and the crushed particles are fed to the fluidized-bed crushed particle burner (or secondary burner), which combusts carbon and converts heavy metal carbides to oxides. The batch of feed is fluidized with carbon dioxide and induction heated prior to the introduction of oxygen. Product from the secondary burner is pneumatically transported to the secondary burner product bunker. The economics of fuel reprocessing require an optimal separation of fissile and fertile particles, since there are penalties associated with crossover from fissile to fertile and vice versa. The pilot plant is also expected to be able to process fuel of the type used in the Fort St. Vrain (FSV) HTGR reactor. In this case, both the fissile and fertile particles have TRISO coatings, so after particle classification both fractions are separately crushed and burned. 


\section{EQUIPMENT DESCRIPTIONS AND SUMMARY OF QUALIFICATION TESTING}

\subsection{FUEL ELEMENT SIZE REDUCTION}

A cascade of crushers (two overhead eccentric jaw crushers, a doubleroll crusher, a vibrating screener, and an oversize pulverizer) are mounted in one frame, designated UNIFRAME (Ref. 3; also see Fig. 5). A ventilation enclosure surrounds the crushers to prevent escape of dust (see Fig. 6). The product is conveyed pneumatically to a crusher product bunker. The air used for conveying is drawn into the UNIFRAME through the top, so the pressure within the ventilation enclosure is slightly below atmospheric. Care was taken in the design stage to minimize areas where dust could collect.

The primary crusher reduces the fuel elements to less than $0.15-\mathrm{m}$ ring size, the secondary crusher to less than $0.05-\mathrm{m}$ ring size, and the tertiary roll crusher to less than $4800 \mu \mathrm{m}$. The tertiary crusher product discharges onto the screen, which diverts oversize material to the oversize pulverizer, which is a single roll moving eccentrically between two wear plates.

Qualification tests with the primary crusher led to the selection of a $0.05-\mathrm{m}$ close side setting and a $14 \mathrm{deg}$ nip angle. The angle of the stationary jaw is adjustable. The close side setting can be varied by installing toggles of varied lengths. The secondary crusher, which has a close side setting of $3.9 \mathrm{~mm}$ and a curved wear surface, generally worked we11, but in some runs some fragments bridged across the top of the crushing cavity, which was consequently modified by extending it and providing a 14 deg nip angle. The tertiary crusher worked satisfactorily. The screen, which was a plate with circular holes, blinded quickly and was, therefore, replaced with a wire mesh, below which are self-cleaning 


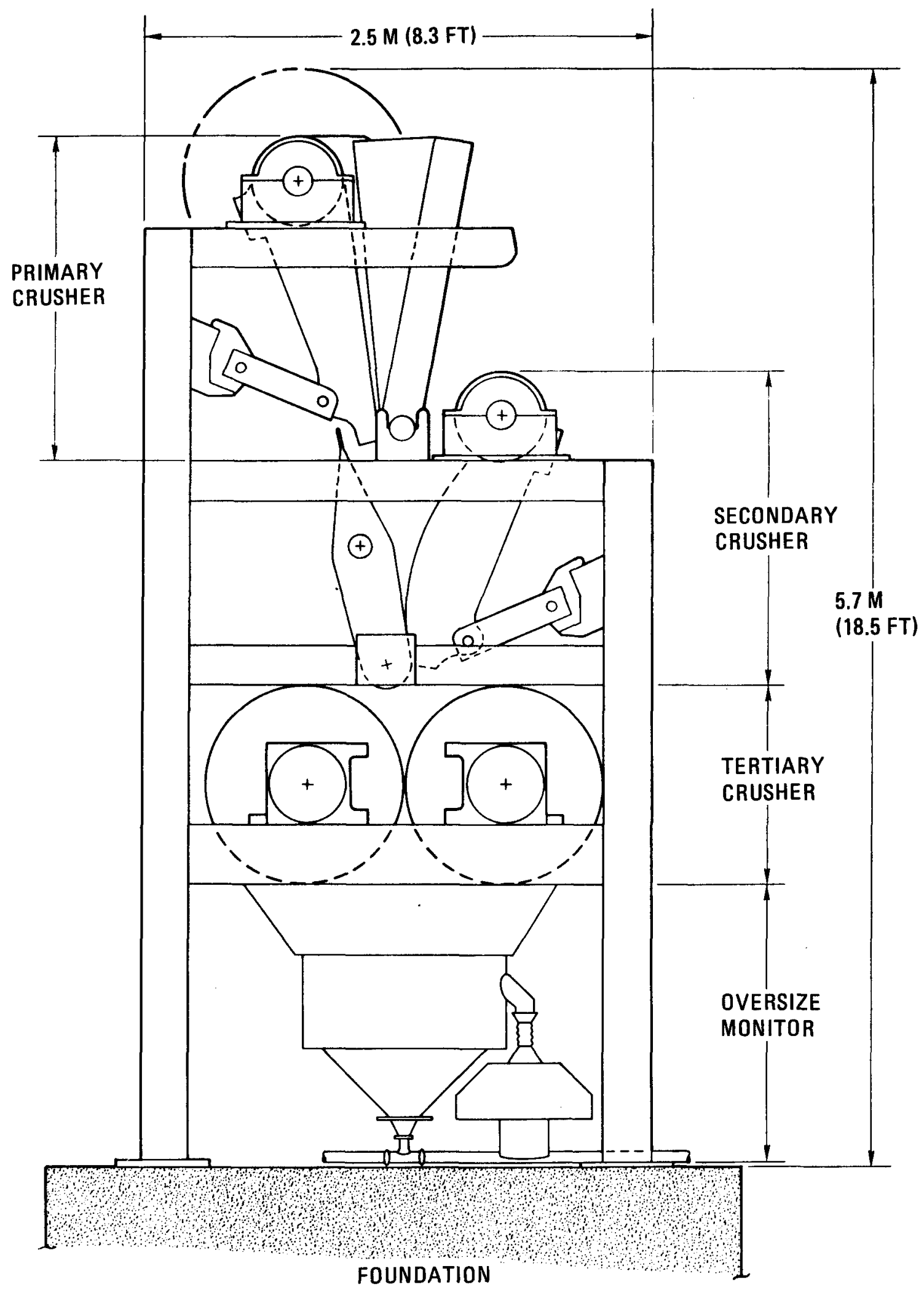

Fig. 5. UNIFRAME machine frame 


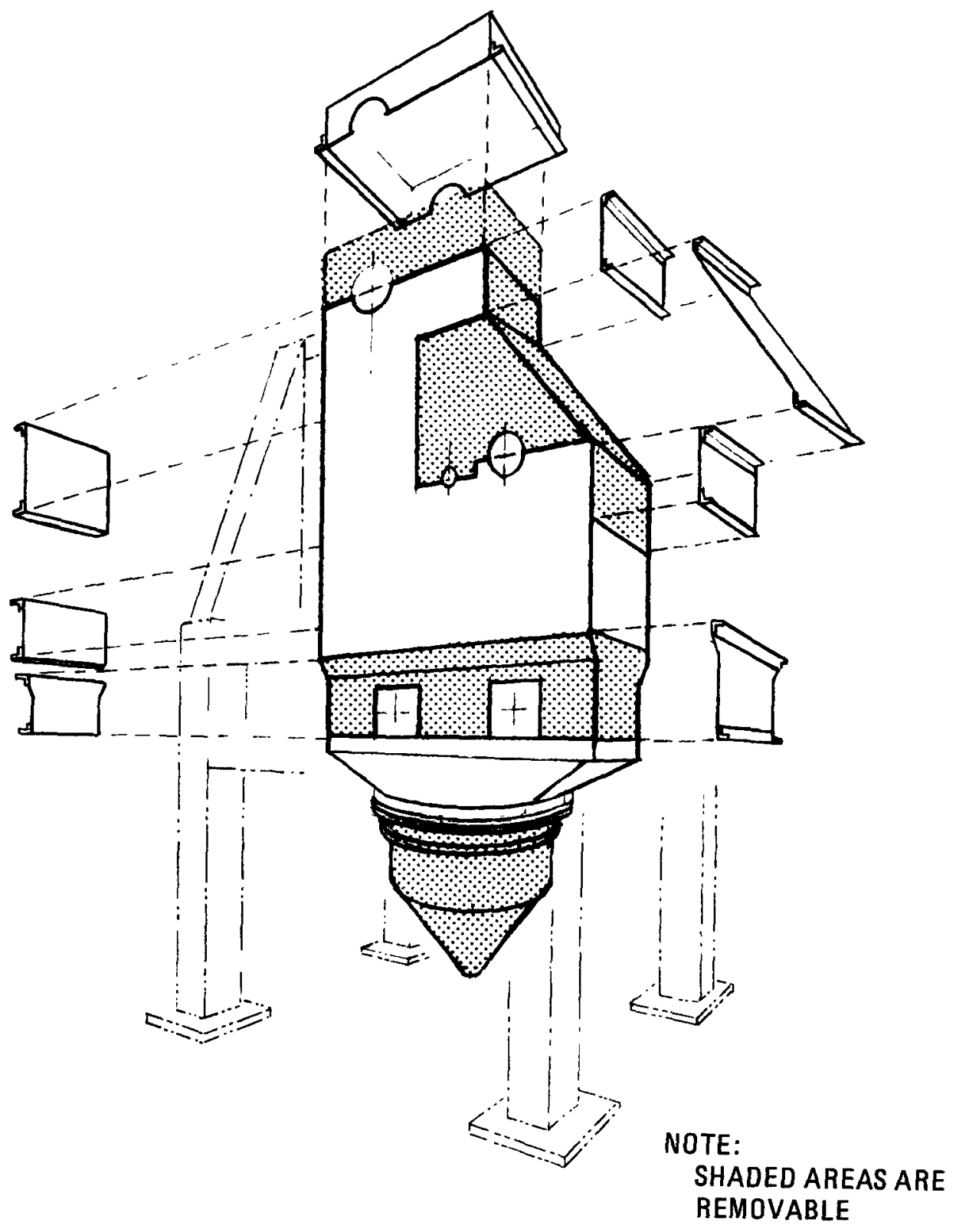

Fig. 6. UNIFRAME ventilation enclosure 
devices. System testing demonstrated that a fuel element could be crushed within the allotted 15-min period. Both the screener and the oversize pulverizer discharge into the pneumatic conveying line, and material tended to flow preferentially from the equipment item closest to the collection hopper. This condition was corrected by intermittent operation of the oversize crusher. A discharge valve was installed as a second corrective measure.

\subsection{PRIMARY BURNER}

The 40 $\mathrm{cm}$ primary burner is shown in Fig. 7. Operating guidelines are summarized in Table 1. During the course of operation, the bed composition ranges from 83 to less than 1 wt \% carbon. The bed density increases by a factor of five.

The major design problems have included (1) the requirements for a specialized gas distributor, (2) combustion of the excessive mass of fine particles elutriated from the bed, and (3) development of a safe, reliable means of operation using automatic controllers.

The optimal distributor was found by experiment to be a 90 -deg included-angle perforated cone. The recycle of fines, which account for $30 \%$ of the carbon fed to the burner, and which are formed in crushing and burning, can be achieved by pneumatic injection from pressurized hoppers (see Fig. 7; also Ref. 4). The burner automatic control incorporates a digital process controller with an all analog input/output interface. There are five principal functions to be performed by the control system (see Table 2; also Ref. 5).

The degree to which the process control computer has full automatic control has been steadily increasing with successive burner runs. At the gas velocities used $(1.0$ to $1.4 \mathrm{~m} / \mathrm{s})$, the bed is slugging. Oxygen is added through the fluidizing cone and a midreactor penetration. The midreactor oxygen is needed to burn the fines in the zone above the bed. 


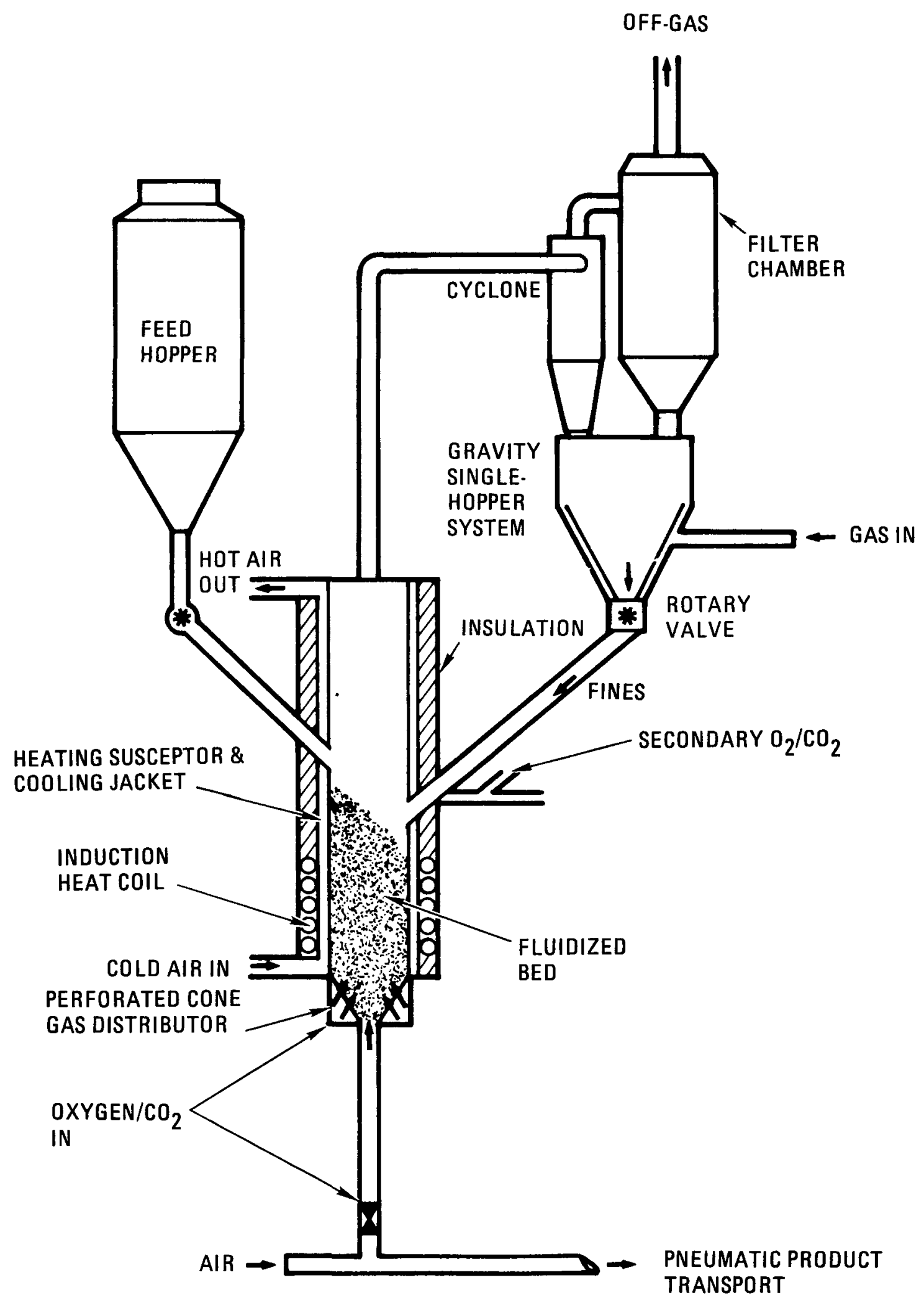

Fig. 7. 40-cm primary burner configuration 
TABLE 1

OPERATING GUIDELINES SUMMARY, PRIMARY FLUIDIZED BED BURNER

\begin{tabular}{l|c}
\hline Principal Conditions & Guidelines \\
\hline Operating mode & Semicontinuous batch \\
Startup & Induction heater \\
Gas distributor & Perforated cone \\
Feed system & Gravity/rotary valve \\
Product removal & Gravity/pneumatic \\
Feed/product control & Metered feed/batched \\
Heat removal & product \\
Temperature & Air cooling via annular \\
Pressure & shroud \\
& $900 \pm 50^{\circ} \mathrm{C}$ \\
Materials & Less than 15 psig at \\
Vessel & all vessel 1ocations \\
Auxiliaries & \\
\hline
\end{tabular}

(a) Product of Cabot Corporation 
TABLE 2

PRIMARY BURNER MAJOR CONTROL FUNCTIONS

\begin{tabular}{|c|c|c|c|}
\hline Function & Method of Control & Type of Sensor & Control Criteria \\
\hline \multirow[t]{2}{*}{$\begin{array}{l}\text { Fluidized-bed } \\
\text { heating }\end{array}$} & $\begin{array}{l}\text { Induction heater cascaded to } \\
\text { bed/vessel/susceptor } \\
\text { temperature }\end{array}$ & $\begin{array}{l}\text { I.S.A. Type K (Chromel-P/ } \\
\text { alume1) - thermocouples }\end{array}$ & $\begin{array}{l}\text { (1) Heat fresh feed or parti- } \\
\text { cle beds to ignition tem- } \\
\text { peratures }\left(700^{\circ} \mathrm{C}\right) \text { in } \leq 2 \mathrm{~h} \text {; }\end{array}$ \\
\hline & & & $\begin{array}{l}\text { (2) Maintain clamp to hub tem- } \\
\text { perature differential } \\
<112^{\circ} \mathrm{C} \text { for vessel flanges. }\end{array}$ \\
\hline $\begin{array}{l}\text { Post-ignition } \\
\text { bed tempera- } \\
\text { ture control }\end{array}$ & Adjust oxygen flow & Type $\mathrm{K}$ thermocouples & $\begin{array}{l}\text { Control temperatures within } \\
\pm 10^{\circ} \mathrm{C} \text { of set points }(\sim \pm 1 \%)\end{array}$ \\
\hline Oxygen flow & $\begin{array}{l}\text { Equal percentage control } \\
\text { valve }\end{array}$ & $\begin{array}{l}\text { Precision gas flowmeter } \\
\text { (Swirlmeter) }\end{array}$ & Flow within $\pm 3 \%$ of set point \\
\hline $\begin{array}{l}\text { Fluidizing gas } \\
\left(\mathrm{CO}_{2}\right) \text { flow }\end{array}$ & $\begin{array}{l}\text { Equal percentage control } \\
\text { valve: adjust } \mathrm{CO}_{2} \text { flow set } \\
\text { point based on bed tempera- } \\
\text { ture to malntain a constant } \\
\text { total gas flow velocity }\end{array}$ & $\begin{array}{l}\text { Precision gas flowmeter } \\
\text { (Swirlmeter) }\end{array}$ & Flow within $\pm 3 \%$ of set point \\
\hline \multirow[t]{3}{*}{ Vessel cooling } & $\begin{array}{l}\text { Adjust cooling air flow } \& \\
\text { maintain proper cooling air } \\
\text { blower discharge pressure }\end{array}$ & $\begin{array}{l}\text { Type } K \text { thermocouples/ } \\
\text { flow averaging (Annubar) } \\
\text { Pitot tubes }\end{array}$ & $\begin{array}{l}\text { (1) Maintain full bed at } 900^{\circ} \mathrm{C} \\
\text { while burning at } 800 \mathrm{~g} \\
\text { carbon/min; }\end{array}$ \\
\hline & & & $\begin{array}{l}\text { (2) Air flow within } \pm 3 \% \text { of set } \\
\text { point; }\end{array}$ \\
\hline & & & $\begin{array}{l}\text { (3) Maintain temperatures } \\
\text { within } \pm 10^{\circ} \mathrm{C} \text { of set point } \\
(\sim \pm 1 \%) \text {. }\end{array}$ \\
\hline
\end{tabular}


A significant amount of development work is accomplished in a $20-\mathrm{cm}$ primary burner, which is separate from the pilot plant.

\subsection{CLASSIFIER, PARTICLE CRUSHER, AND SECONDARY BURNER}

Primary burner product, consisting of TRISO-coated fuel particles and bare $\mathrm{ThO}_{2}$ microspheres, is air classified to separate these two streams. Crossover can be held to no more than 1 wt $\%$ if the feed contains few broken fuel particles.

The classifier column design incorporates a zigzag geometry that yields higher separation efficiencies than a straight column. Airflow up through the column is metered by varying a vacuum pump speed. Solid stream feed addition is through the side of the column. Solid feed rate is controlled by using a vibratory feeder.

Those particle streams containing TRISO-coated particles are crushed to expose the carbide kernel and inner carbon coatings. This crushed particle stream is then oxidized in a secondary burner to yield a heavy metal oxide and SiC shell mixture, which is, in turn, leached to isolate the heavy metals.

A double-roll crusher is used for comminution of the fuel particles. This type of crusher was chosen to yield maximum crushing efficiency (i.e., no unbroken fuel particles) and to maximize product size distribution, since finer powders are more difficult to fluidize evenly.

The secondary burner is a batch fluidized-bed reactor with a flat perforated inlet gas distributor plate and in-vessel off-gas filters. Process heating is supplied by an induction heater, while cooling is accomplished by air flow through annular cooling jackets. Crushed particle feed is supplied by a gravity-pneumatic feeder at the upper end of the vessel. Product is removed through a valve port just above the distributor plate. 
Sintered metal cylindrical filters separate the off-gas from entrained bed material. They are cleaned using a reverse jet blowback technique.

The burning cycle, optimized through a systematic variation of the main operating parameters, is as follows:

Feed batch and induction heat to $600^{\circ} \mathrm{C}$, using $\mathrm{CO}_{2}$ for fluidization. Ignite by gradually increasing the gas flow to $0.80 \mathrm{~m} / \mathrm{s}$ of pure $0_{2}$. External heating and cooling are on demand to keep the bed at $850^{\circ} \mathrm{C}$ during the run. When the burning rate decreases to a preset value, fluidize the bed with pure $\mathrm{CO}_{2}$ and $\operatorname{cool}$ to $500^{\circ} \mathrm{C}$. Pneumatically transport the product to a storage bunker.

Initial scoping tests were made on a $10-\mathrm{cm}$ diameter burner; this generated sufficient design data to allow a $20-\mathrm{cm}$ diameter burner to be constructed (see Fig. 8). A total of $600 \mathrm{~kg}$ of crushed fuel particles have been processed in this larger burner. Product carbon content has averaged less than $1 \%$.

It is significant to note that these high combustion efficiencies have been realized without external recycle of carbon fines. The in-vessel filters constrain the fine material to a region close enough to the slugging fluid bed that they are mixed back into the bed where they are able to combust.

Automatic data logging has been used during secondary burner runs. Equipment used to do this is shown schematically in Fig. 9. Postoperation analysis of variables has been factlitated by this data recording, with time plots of variables being especially helpful. 


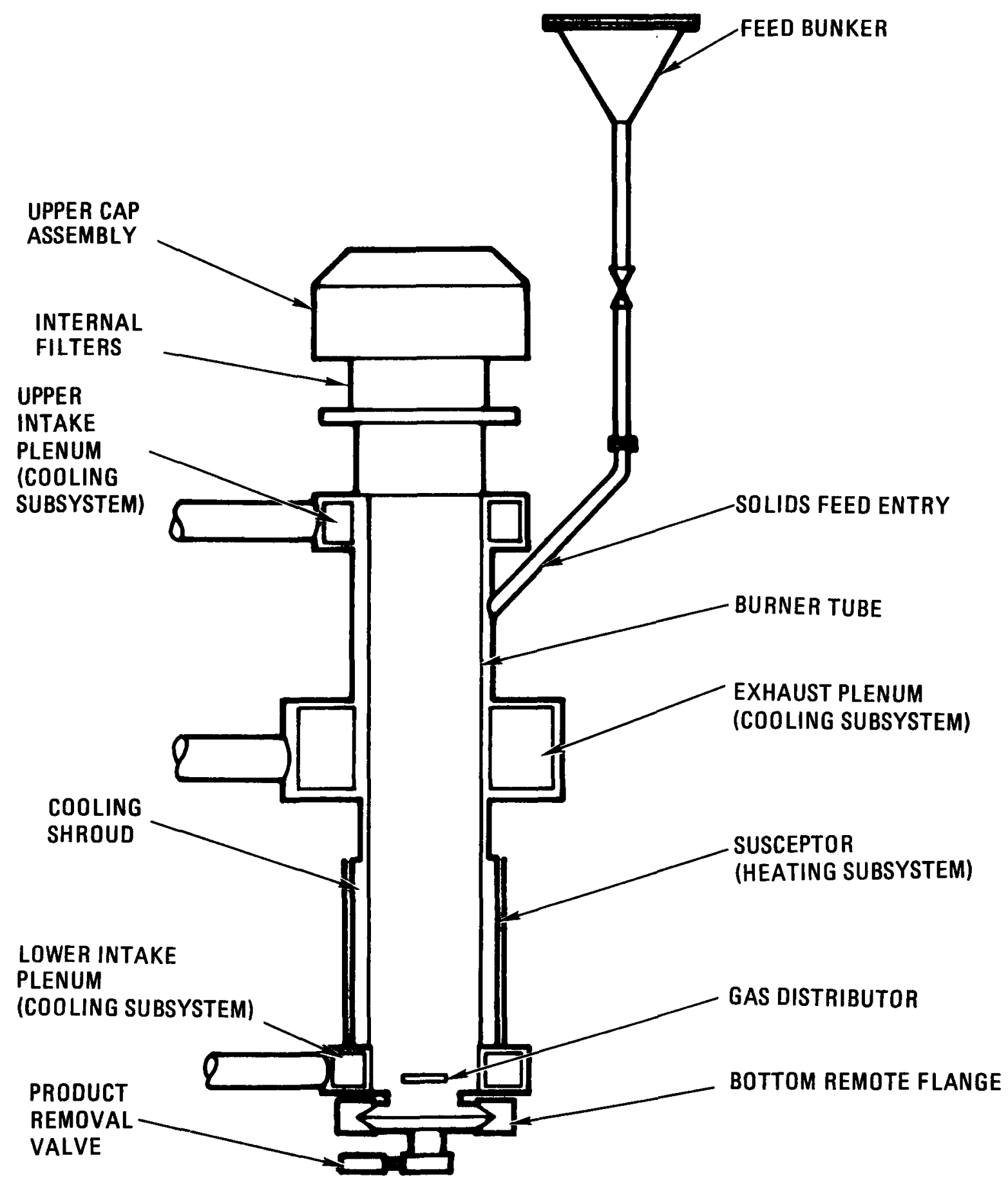

Fig. 8. 20-cm primary burner configuration 


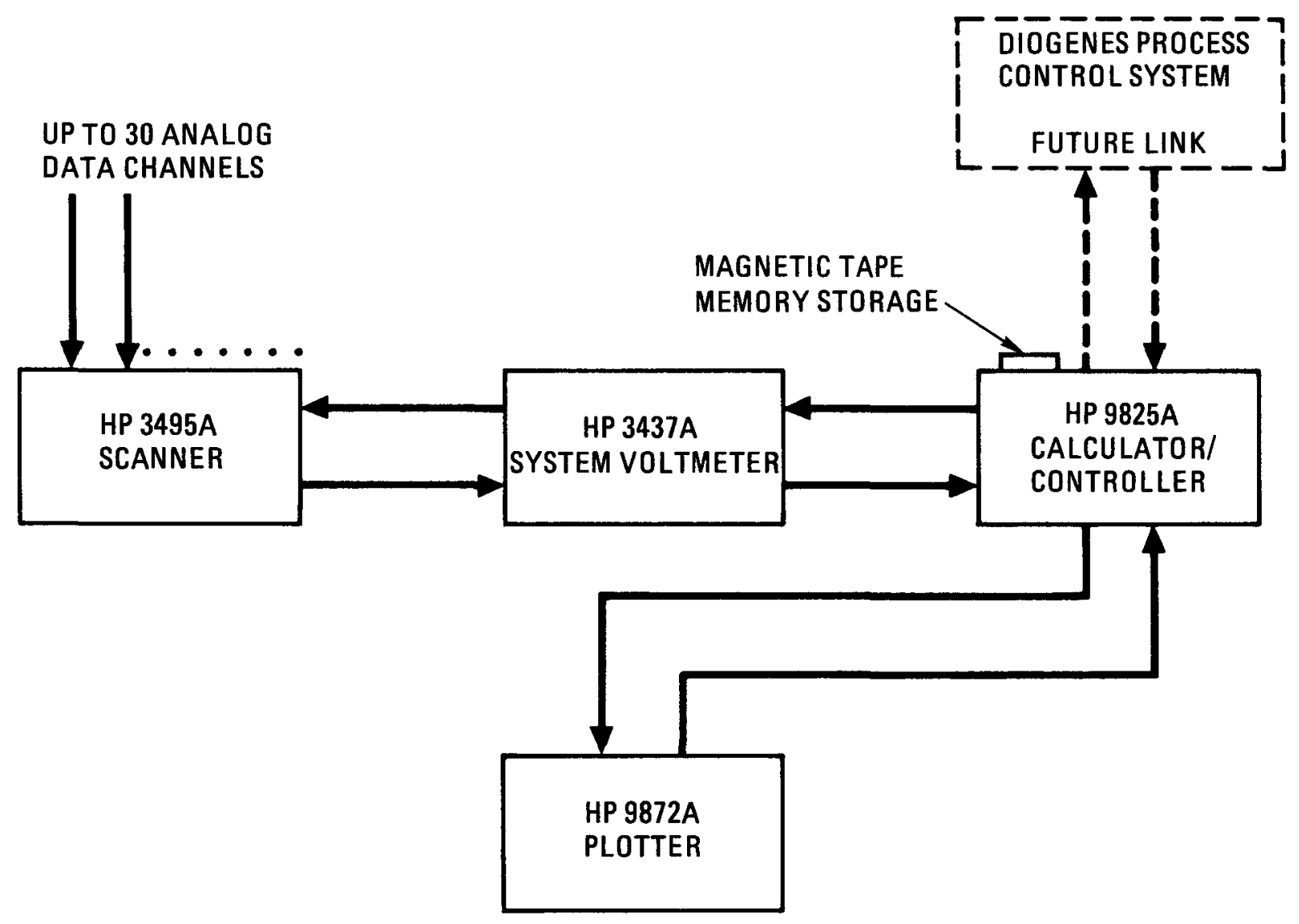

Fig. 9. Data acquisition and processing block diagram 


\subsection{SOLIDS HANDLING}

The solids handling system is divided into six subsystems. Each of these subsystems is required to receive material from the preceding operation, transport it, store it, weigh it, recover it from storage, and feed it to the next step.

Pneumatic conveying is used to transport material. The blowers are at the ends of the conveying lines, such that the pressure in the system is below atmospheric. Solids are separated from the conveying gas with in-bunker filters. Valves in the conveying lines, off-gas 1ines, and at bunker outlets isolate the bunkers. Electronic load cells are used to weigh the bunker contents. High-level alarms in the walls of the bunkers prevent overfilling. Electrical sequencing is used for actuating valves and blowback of the filters and blowers when conveying a batch. Electrical interlocks prevent conflicts.

The qualification testing was divided into two phases: (1) component testing, followed by (2) subsystem testing. Component testing is concerned with confirming the suitability of the equipment selected for the pilot plant. Subsystem testing is process oriented and is concerned with conveying system capacities and fuel particle breakage, which adversely affects the separation of the two particle types.

\subsubsection{Component Testing}

Figure 10 is a sketch of a typical bunker assembly, showing most of the components. A description of major components, together with major test results, is given below.

3.4.1.1. Inlet Filters. At the beginning of each transport 1ine, there is a HEPA filter. Experiment has shown that HEPA filters adequately perform their dual role of preventing stray particulates from entering the line, and in the event of a mishap, preventing particulate material from leaving the 1ine. 


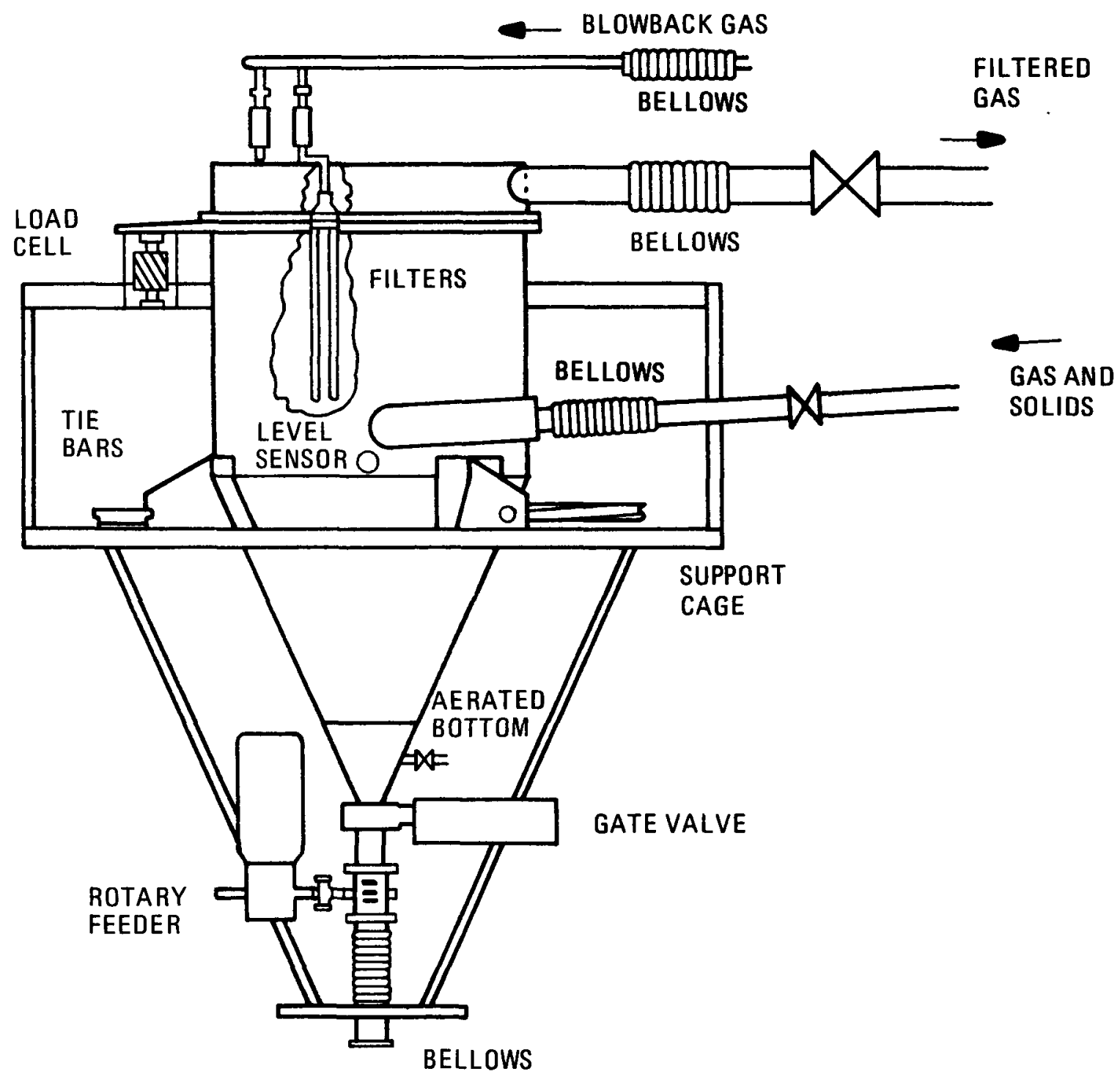

Fig. 10. Typical bunker assembly 
3.4.1.2. In-Bunker Filters. Inside the bunkers are porous stainless steel filter pipes. They have a mean pore size of $5 \mu \mathrm{m}$. The filters are cleaned by a reverse flow of high pressure $\mathrm{CO}_{2}$. Sample wipes, taken before and after testing from the inside of the filter exhaust line, showed that no significant quantities are passing through the filters.

3.4.1.3. Level Sensors. These operate on the principle of interrupting an ultrasonic beam propagated between two sensors. There is a tendency for a coating of fines on the faces to activate the alarm, and improvements are being sought.

3.4.1.4. Feeders. Feeders are used throughout the system. The variety of particle densities in the process makes use of fixed-size orifices impractical. Rotary feeders (either 0.05 or $0.10 \mathrm{~m}$ ) are used throughout, except for a vibrating feeder for the classifier, a variable-width knifegate under the primary burner, and a Volkswagon automobile valve in the secondary burner. In order to avoid crunching in the rotary feeders, the vanes were trimmed, giving a clearance of approximately $3 \mathrm{~mm}$. Rotation is required for crushed graphite or TRISO particles.

3.4.1.5. Weigh Cells. The bunkers rest on load cells which record the material weight continuously. Several special provisions have been made to ensure that accurate readings are obtained. The bunker assemblies are supported on three load cells. All connecting lines either contain metal bellows, or if they are narrow, are unsupported over at least 61 horizontal $\mathrm{cm}(2 \mathrm{ft})$. In order to prevent rotation of the bunkers, tie bars are attached to the bunker and the support cage.

\subsubsection{Conveying Tests}

Conveying data have been collected in all subsystems. The requirement to minimize fuel-particle breakage conflicts with the need to use a sufficiently high conveying velocity so that the chance of saltation is minimized. The pressure-drop results have been compared with the predicted 
values in the formula recommended by the Engineering Equipment Manufacturers Association (Ref. 6). The predicted values are consistently twice as high as the observed values. Therefore, a useful correlation has emerged.

The transport of fuel particles and/or crushed graphite and mixtures tends to become unstable at mean gas velocities below $20 \mathrm{~m} / \mathrm{s}$. At such velocities, the particle breakage is generally below $0.5 \%$.

\subsubsection{Samplers}

Samples are taken at several points throughout the system. Commercially available samplers were tested in a solids-handling test rig, which comprises two bunkers, a variable speed blower, and a variablegeometry conveying system. The accuracy of the samples taken from gravity flow and pneumatic conveying lines were studied. Thereafter, samplers were installed prior to sequential operation.

\subsubsection{Flow Property Measurement}

A Jenike shear cell was used for measuring the flow properties of the various solids occurring in the process. Such measurements can be used to design gravity flow equipment (Ref. 7). 


\section{FEED MATERIAL}

Twenty standard LHTGR fuel elements were utilized as the feed for pilot plant sequential operation. Each fuel element contained 1566 fuel rods. Prior to loading, 70 rods weighed an average $28.23 \mathrm{~g}$ per rod. The rod composition was $16 \%$ fissile fuel particles, $55 \%$ fertile fuel particles, and $29 \%$ matrix and shim. The fissile fuel particles were weak acid resin (WAR) TRISO, fabricated with depleted uranium. The heavy metal content of the fissile particles was approximately 13 wt \%. The fertile fuel particles were $\mathrm{ThO}_{2}$ BISO with approximately 56 wt \% heavy metal. The total heavy metal weight per block was $0.920 \mathrm{~kg}$ uranium and $13.616 \mathrm{~kg}$ thorium. 


\section{SAMPLING, PRELIMINARY TESTS AND PLANS}

Prior to beginning the sequential operations, discussion was held between GA personnel from the Chemistry, Quality Assurance, and Recycle Development Departments. The discussion objective was to establish a sampling plan and the analytical technique for determining particle breakage. Data from this test would be unique, since all previous tests had been done with simulated feeds made up for each processing step and were nonsequential.

The following plan was followed to determine the quantity of particles broken in fuel element manufacture (rather than head-end processing):

1. One batch of each of the excess fissile and fertile particles remaining after loading the elements was split sampled. The quantity of uranium and thorium from breakage and possible exterior contamination was determined without burning back the particles. This compensated for initial breakage and contamination when determining sequential operations breakage. It also allowed determination of the fissile particle breakage due to burning back particles (since residue was subsequently burned back, and uranium and thorium determined a second time). Total thorium and uranium content were determined by a final crushburn-back analysis. The uranium and thorium detected from breakage and possible exterior contamination were both less than $1 \mathrm{mg} / \mathrm{g}$ of sample. The uranium detected from burning back of the fissile particles was also less than $1 \mathrm{mg} / \mathrm{g}$ of sample.

2. A second split sample of the fissile and fertile particles was $\mathrm{X}$-ray examined for particle breakage. No broken fissile particles were detected and only one in 3000 broken fertile particles were observed. 
3. Two green fuel rods were submitted for dissolution of the matrix, followed by analysis identical to that of the loose fuel particles. Again, less than $1 \mathrm{mg} / \mathrm{g}$ of sample for both uranium and thorium was detected in all cases. This indicated that no additional particle breakage occurred during rod manufacture.

Pilot plant sampling points were designated on a sequential operating schedule. The following procedure was used to determine the particle breakage in the samples taken at various locations in the transport system:

1. The samples were screened and separated into $+425-\mu \mathrm{m}$ and $-425-\mu \mathrm{m}$ fractions.

2. The sample fractions were oxidized in air at approximately $900^{\circ} \mathrm{C}$ to remove the burnable carbon and prevent its interference with the subsequent analysis.

3. The residues were leached in thorex solution and analyzed for thorium and uranium content. These tests indicated not only the uranium and thorium present from broken particles, but also the total thorium present due to BISO kernel exposure by the burning process. To obtain an estimate of BISO particle breakage in these samplers, it was assumed that thorium present in the $+425-\mu \mathrm{m}$ fractions was from whole particles and in the $-425-\mu \mathrm{m}$ fraction was from broken particles. Since whole BISO kernels are larger than $425 \mu \mathrm{m}$, and crossover after air classification was expected to be almost entirely from fragments less than $425 \mu \mathrm{m}$, this assumption was considered reasonable.

4. The residues from the initial thorex leach were dried, crushed, and reburned in air at $900^{\circ} \mathrm{C}$ to remove the carbon from inner coating layers.

5. The residues from the return were leached in thorex solution and analyzed for thorium and uranium content. These results 
substantiate uranium present from whole particles. From these results and results of the initial leach, the percent of broken particles was calculated. The accuracy of the uranium analysis using the crush-burn-leach method was estimated by the Chemistry Department at $\pm 0.1 \%$. The accuracy of the thorium analysis was estimated at $\pm 0.5 \%$. 


\section{RESULTS OF INITIAL SEQUENTIAL OPERATION}

\subsection{UNIFRAME OPERATIONS}

After being crushed, the first three fuel elements used in the sequential operations were sampled by manually collecting product from the screener and oversize crusher and putting each separately through a 12 to 1 splitter. The products from these elements were placed in barrels, transported from the barrels to the crusher product bunker, and again sampled with a cross-cutting sampler. The average conveying velocity used was approximately $18 \mathrm{~m} / \mathrm{s}$. The particle size distributions and the particle breakage were analyzed both before and after transport. No significant differences were detected. The particle breakage results are shown in Table 3 . The before and after size distributions are shown in Fig. 11.

The next four elements were crushed and transported individually to the crusher product bunker in the normal mode of the present crushertransport system design. Each crushed element was separately sampled using the cross-cutting sampler, in line between the crushed product removal system and the primary burner feed system, as they were transported to the primary burner feed bunker. One of these fuel elements (FE-003) was transported at approximately $18 \mathrm{~m} / \mathrm{s}$ average conveying velocity. The remaining three were transported at approximately $25 \mathrm{~m} / \mathrm{s}$. The particle breakage results are shown in Table 4.

The next six elements were crushed in rapid succession and combined in the crushed product bunker. No equipment or operational problems were encountered until after the crushing of the sixth element was complete. During the normal cleanout period after crushing, bearing overheat on the 
TABLE 3

CUMULATIVE PARTICLE BREAKAGE FROM

UNIFRAME AND TRANSPORT SYSTEM (FE-025)

\begin{tabular}{l|c|c|}
\hline Particle & $\begin{array}{c}\text { Broken } \\
(\%)\end{array}$ & Description \\
\hline Fertile & 0.62 & Sample of FE-025 after crushing (a) \\
Fissile & 1.57 & \\
Fertile & 0.45 & $\begin{array}{l}\text { Sample of FE-025 after crushing and transport } \\
\text { at } 18 \mathrm{~m} / \mathrm{s} \text { average gas velocity from a barrel (a) }\end{array}$ \\
\hline
\end{tabular}

(a) LHTGR, H-451 graphite, depleted TRISO/BISO fuel elements. 


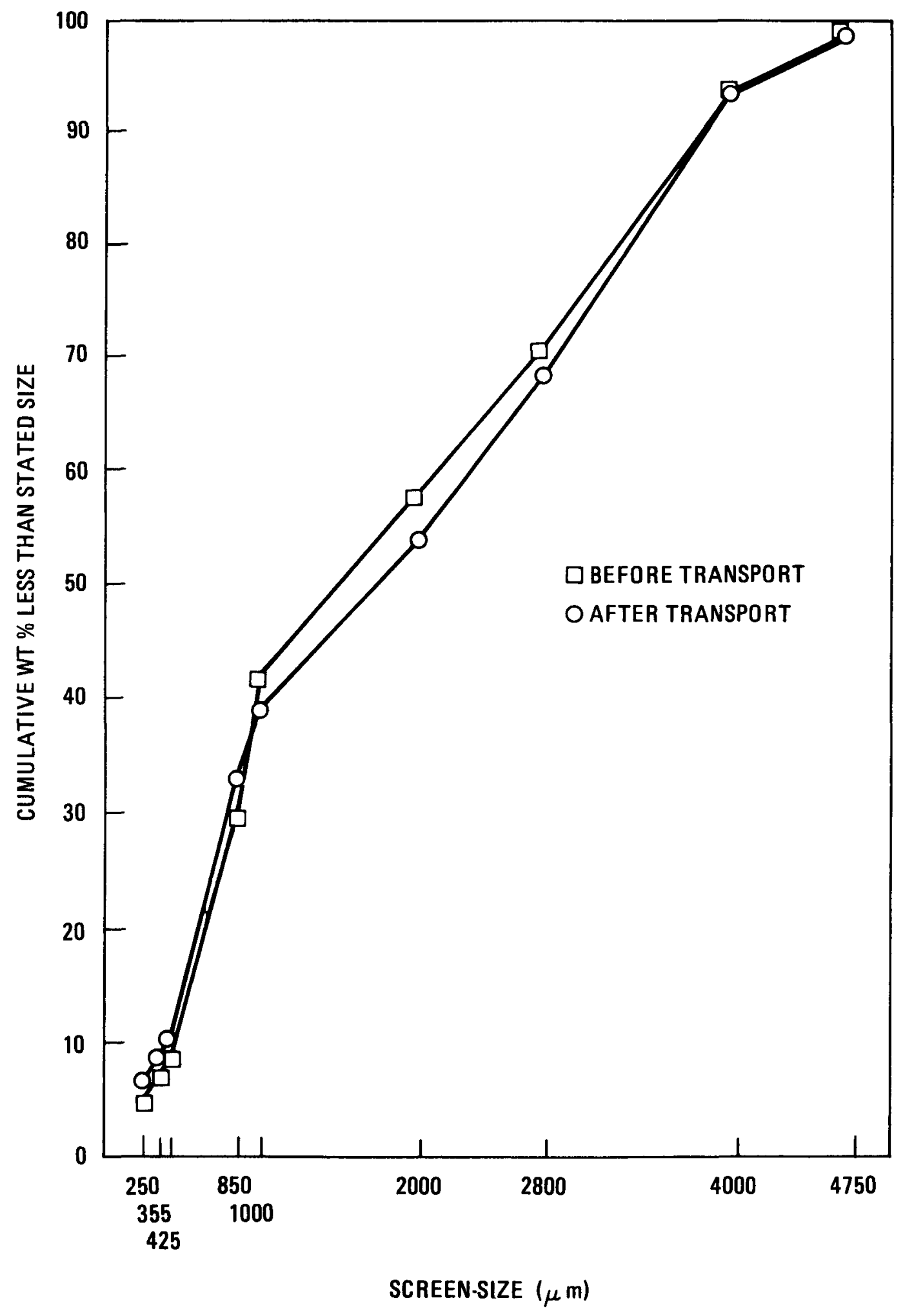

Fig. 11. Particle size distributions before and after transport 
TABLE 4

CUMULATIVE PARTICLE BREAKAGE FROM UNIFRAME

AND TRANSPORT SYSTEM AT VELOCITIES OF $18 \mathrm{~m} / \mathrm{s}$ AND $25 \mathrm{~m} / \mathrm{s}$

\begin{tabular}{|c|c|c|}
\hline Particle & $\begin{array}{c}\text { Broken } \\
(\%)\end{array}$ & Description \\
\hline & 0.52 & \multirow{4}{*}{$\begin{array}{l}\text { FE-003 transported at } 18 \mathrm{~m} / \mathrm{s} \text { from UNIFRAME } \\
\text { (a) } \\
\text { FE-002 transported at } 25 \mathrm{~m} / \mathrm{s} \text { from UNIFRAME (a) }\end{array}$} \\
\hline Fissile & 4.22 & \\
\hline Fertile & 0.80 & \\
\hline Fissile & 7.34 & \\
\hline
\end{tabular}

(a) LHTGR, H-451 graphite, depleted TRISO/BISO fuel elements. 
secondary crusher forced its shutdown. The cause of this problem will be investigated for incorporation into the previously planned upgrading of lubrication systems for hot cell use.

Health physics monitoring of the area up to this point revealed no radioactive material spills which could be attributable to crushing operations. Radiation detected was essentially at background levels. No activity was detected in the fuel charging area or on the floor at the base of the crusher. Less than $10 \mathrm{dpm} / 100 \mathrm{~cm}^{2}$ were detected on catwalks and machine surfaces.

Because of the overheating of the secondary crusher outboard bearing and its potential for seizing, the remaining size-reduction operations were spaced to allow cooling of the bearing. The bearing did not cause interruptions during these size reductions and no other problems were detected.

All of the final 13 fuel elements crushed were transported to the primary burner feed bunker as needed. Samples of these semicontinuously transported materials were collected with the cross-cutting sampler. The particle-size distributions of these materials closely resembled those of an earlier individually sampled element, as shown in Fig. 12. The particle breakage analysis is shown in Table 5. A summary of the crushing operations is given in Table 6.

Analytical results indicate the lowest particle breakage occurs in materials transported from barrels at a continuous feed rate and moderate gas velocity $(18 \mathrm{~m} / \mathrm{s})$. The next lowest occurred in materials transported from the UNIFRAME at $18 \mathrm{~m} / \mathrm{s}$. The highest particle breakage occurred in materials transported from the UNIFRAME at the higher gas velocities $(25 \mathrm{~m} / \mathrm{s})$.

The difference between the particle breakage in transport from barrels and transport directly from the UNIFRAME may be attributed to two 


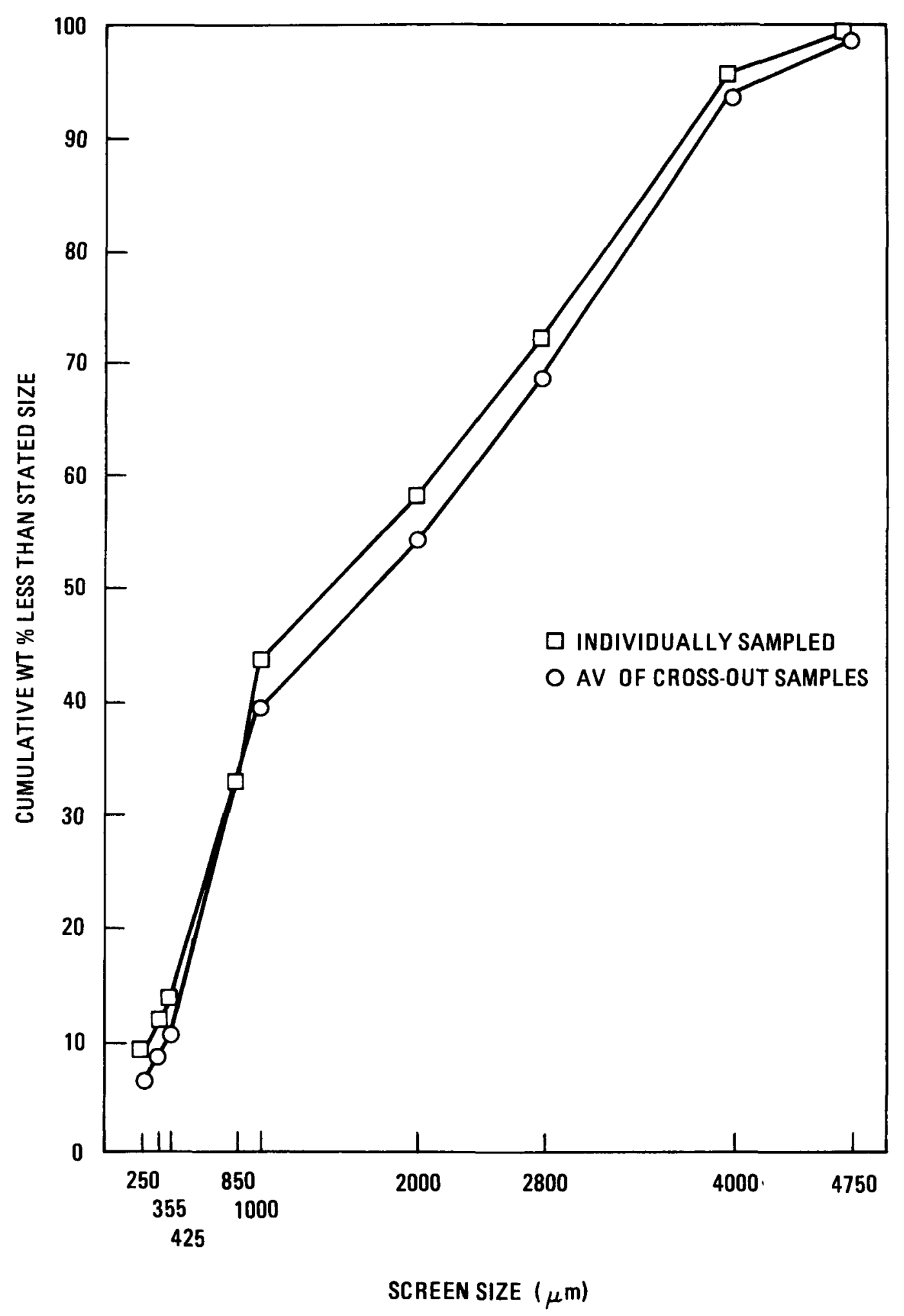

Fig. 12. Comparison of particle size distributions between individual and average crosscut samples of crushed fuel elements 
TABLE 5

CUMULATIVE PARTICLE BREAKAGE FROM UNIFRAME AND TRANSPORT SYSTEM (SEQUENTIAL ELEMENTS)

\begin{tabular}{|c|c|c|}
\hline Particle & $\begin{array}{c}\text { Broken } \\
(\%)\end{array}$ & Description \\
\hline Fertile & 0.98 & \multirow{2}{*}{$\begin{array}{l}\text { Complete sample of } \mathrm{FE}-005 \text { through } \mathrm{FE}-010 \\
\text { conveyed at } 25 \mathrm{~m} / \mathrm{s} \text { average gas velocity (a) }\end{array}$} \\
\hline Fissile & 8.68 & \\
\hline Fertile & 0.80 & \multirow{2}{*}{$\begin{array}{l}\text { Sample of } \mathrm{FE}-002 \text { conveyed at } 25 \mathrm{~m} / \mathrm{s} \text { average } \\
\text { gas velocity(a) }\end{array}$} \\
\hline Fissile & 7.34 & \\
\hline
\end{tabular}

(a) LHTGR, H-451 graphite, depleted TRISO/BISO fuel elements. 
TABLE 6

FUEL ELEMENT SIZE REDUCTION FOR SEQUENTIAL PILOT PLANT OPERATIONS

\begin{tabular}{|c|c|c|c|c|}
\hline $\begin{array}{c}\text { Element } \\
\text { No. }\end{array}$ & $\begin{array}{c}\text { Weight } \\
(\mathrm{kg})\end{array}$ & $\begin{array}{l}\text { Crushing } \\
\text { Time (s) }\end{array}$ & & \\
\hline 025 & 120.2 & Not observed & & \\
\hline 023 & 117.5 & Estimated 280 & & \\
\hline 022 & 119.9 & Not observed & & \\
\hline 001 & 120.9 & Not observed & & \\
\hline 002 & 120.0 & 250 & & \\
\hline 003 & 120.7 & 252 & & \\
\hline 004 & 123.2 & 246 & & \\
\hline \multicolumn{3}{|c|}{$\begin{array}{l}\text { The following were charged without } \\
\text { cleanout in between: }\end{array}$} & $\begin{array}{c}\text { Charging Time } \\
\text { From Start } \\
\text { of Run (s) }\end{array}$ & $\begin{array}{l}\text { Time Between } \\
\text { Element } \\
\text { Chargings (s) }\end{array}$ \\
\hline 005 & 122.5 & 246 & 0 & - \\
\hline 006 & 123.8 & 256 & 370 & 370 \\
\hline 007 & 123.6 & 260 & 714 & 344 \\
\hline 008 & 122.7 & 226 & 1050 & 336 \\
\hline 009 & 123.2 & 250 & 1410 & 360 \\
\hline 010 & 124.1 & 270 & 1718 & 308 \\
\hline Total & 1582.3 & $\begin{array}{l}\text { Total time } \\
\text { including } \\
\text { cleanout }\end{array}$ & 2520 & \\
\hline
\end{tabular}

The following were charged with cleanout in between:

\begin{tabular}{lll}
\hline 011 & 123.6 & 244 \\
012 & 123.4 & 248 \\
021 & 120.9 & 230 \\
019 & 122.2 & 260 \\
020 & 120.9 & 244 \\
024 & 122.4 & 252 \\
026 & 123.4 & 248 \\
\hline Total & 856.8 & \\
\hline
\end{tabular}


factors: (1) reliable transport from the barrels could be accomplished at a lower average gas velocity $(18 \mathrm{~m} / \mathrm{s})$ than is required for reliable transport from the UNIFRAME $(25 \mathrm{~m} / \mathrm{s})$, and (2) the feed rate from the barrels is nearly constant at $0.26 \mathrm{~kg} / \mathrm{s}$ while the feed rate from the UNIFRAME varies from zero to $0.5 \mathrm{~kg} / \mathrm{s}$. Since conveying velocity is directly related to particle breakage, and mass feed rate is inversely related, fuel elements transported directly from the UNIFRAME could be expected to exhibit increased breakage results, as was the case.

Sequential operations of the UNIFRAME and the crusher product-removal system pointed out the need for improving feed control between systems to minimize particle breakage. Control of the outlet feed rate with a rotary feed valve, similar to the one on the crusher product bunker, will be investigated.

\subsection{PRIMARY BURNING OPERATIONS}

The primary burner feed system functioned normally throughout the sequential operations. Feed rate and conveying velocity were varied about the values determined during earlier nonsequential experiments in order to optimize system performance. A feed rate of $0.45 \mathrm{~kg} / \mathrm{s}$ and an average gas velocity of $18 \mathrm{~m} / \mathrm{s}$ were selected as the basis for future operation with the constant speed blower. These transport conditions closely parallel those used for the first three fuel elements of the sequential tests (transported from a barrel to the hopper, as previously discussed) in which no significant fuel particle breakage was found.

The system pressure drop observed during the experiment correlated within $\pm 20 \%$ of the predicted system pressure drop. The result, along with those for the other systems, is shown on Fig. 13.

The 10-cm (4-in.) rotary feed valve used to meter material into the conveying line to the primary burner feed bunker exhibited satisfactory performance. A valve speed of $30 \mathrm{rpm}$ provides a nominal $0.45 \mathrm{~kg} / \mathrm{s}$ feed 


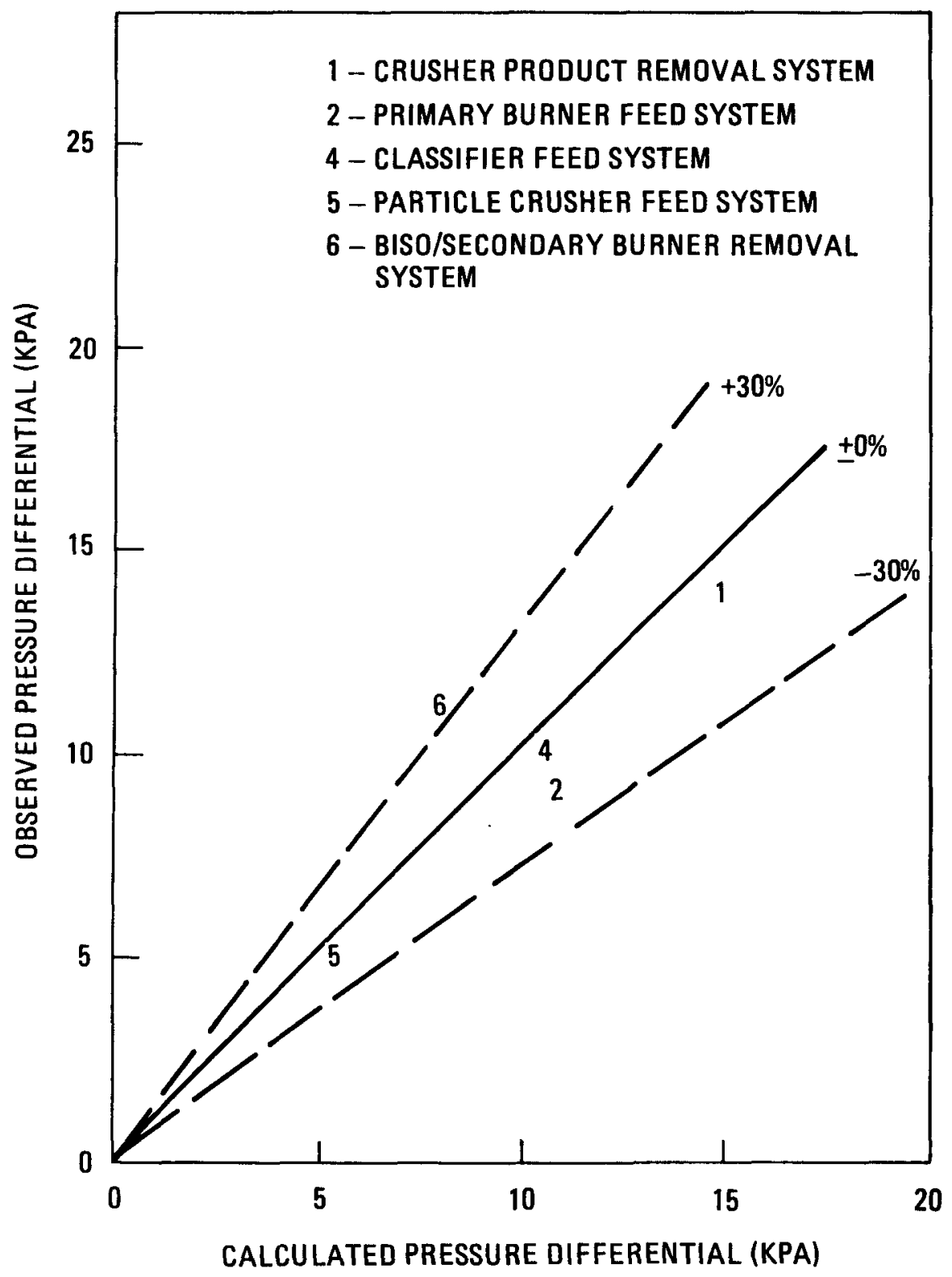

Fig. 13. Observed versus predicted pressure drops for various systems 
rate with crushed LHTGR fuel elements. The valve controls will be automated for future pilot plant operations.

Particle-breakage and particle-size-distribution data discussed previously (with the crusher product removal system) includes rotary valve contribution, since the valve is located between the cross-cutting sampler and the product removal system. Since the breakage and change in size distribution during transfer of the first three elements (under optimum conditions from a barre1) were insignificant for the system, breakage caused by the rotary valve was also insignificant.

No samples were collected of the material transferred in the primary burner feed system. Since the first three fuel elements were transferred under similar conditions, little damage to material is expected here either. A sampler will be installed beneath the primary burner feed bunker in conjunction with planned burner and feed system revisions.

The Orbitran weigh system could not be used effectively during sequential operations, due to the insufficient hopper supports. Material inventory of less than $150 \mathrm{~kg}$ within the hopper had to be maintained to prevent reversible load cell failure and resulting loss of in-hopper material weight. The feed hopper support structures are scheduled for redesign and rework during primary burner modification.

The size distribution of the feed, and the material removed from both fines hoppers are shown in Fig. 14. Material withdrawn in fines samples during operation gave indication of the fines composition trends leading up to the final fines hopper material. Feed material was also sampled prior to putting it in the burner. These samples indicated particle breakage as a result of crushing operation (Table 4 ).

The initial attempt of primary burning during sequential operations was shut down after approximately $3 \mathrm{~h}$ of burning when the bellows in the midreactor fines $/ \mathrm{O}_{2}$ injection line ruptured. 


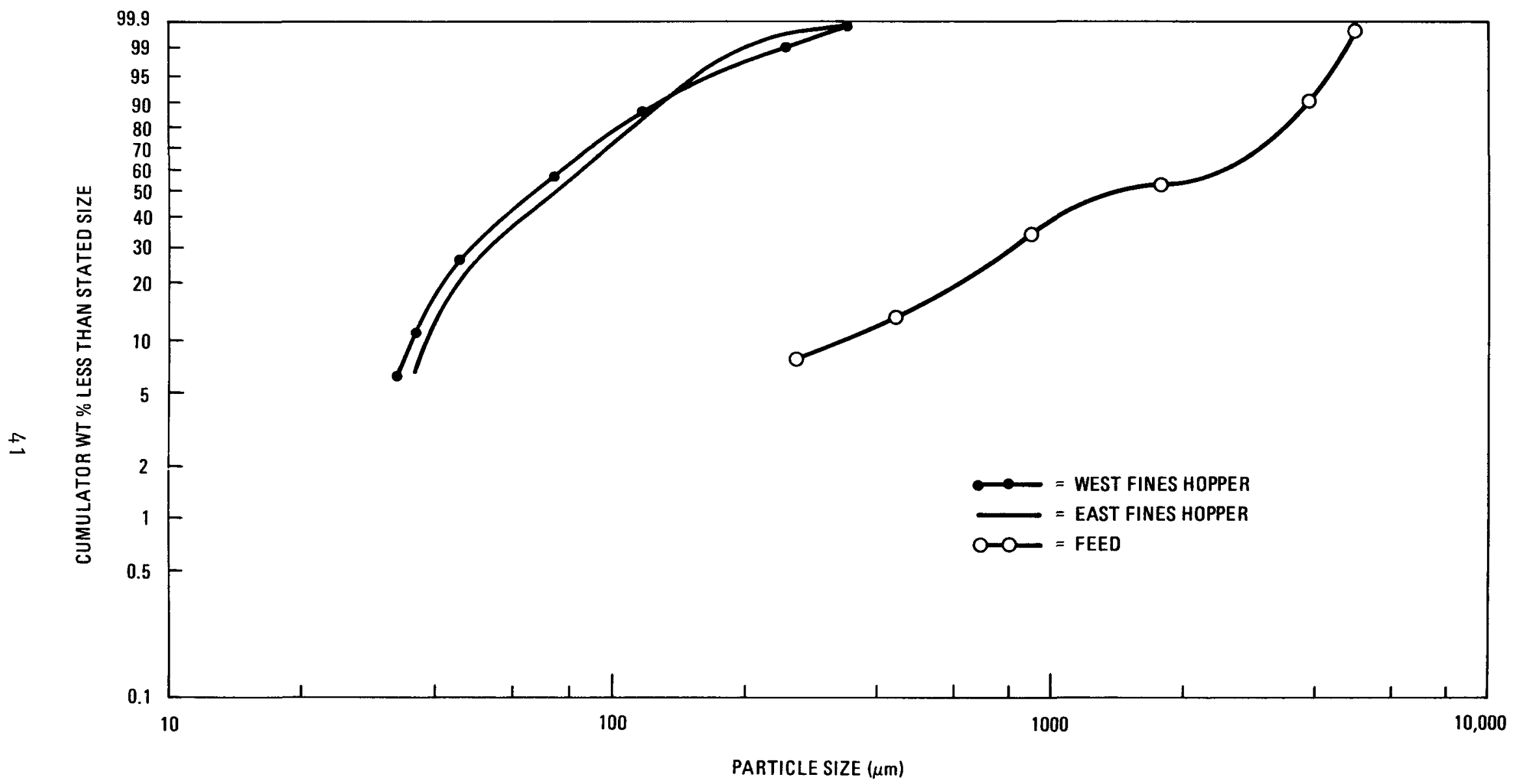

Fig. 14. Material size distribution, 40-cm primary burner 
In the course of the development work on the 40-cm primary burner, two penetrations had been made in the burner vessel. One was used for a bed-level probe and the other for an inlet initially for midreactor oxygen and later for both oxygen and recycling fines (see Fig. 15). A 1.9-cm (3/4-in.) hole was drilled through the burner wall and a studded boss welded on the outside. To this boss was bolted a flange, which was at one end of a braided, unlined bellows. The other end of the bellows was fixed to the outer skin of the insulation shroud. The purpose of the bellows was to deform as the burner vessel heated up and grew downwards relative to the cooling shroud. The fines recycle/midreactor oxygen line was fixed to the outer skin of the shroud to prevent leakage of cooling air. During an earlier run (Run $C$ ), oxygen was added to the burner through this penetration. For the following run (Run D), the fines recycle line was extended such that recycling fines and midreactor oxygen combined prior to passing through the braided bellows into the reactor (see Fig. 16). This run was operated at conditions similar to Run $C$, except that pneumatic above-bed fines recycle was used. Fines were recycled for approximately $22 \mathrm{~h}$. Above-bed recycle resulted in <2 wt \% particle breakage compared to $>6 \%$ breakage with Run $C$ in-bed recycle. The acceptable fines burning and lower breakage of above-bed recycle indicated that it should be used during sequential operation of the pilot plant.

The sequential operation with loaded fuel elements had just reached the end of the initial oxygen ramp (i.e., approximately $95 \%$ of full burn rate) when the emergency shutdown occurred. The careful disassemb1y of the fines and oxygen lines and removal of the circular plate sealing the shroud revealed that the bellows was completely severed at approximately point C (Fig. 15). Between points $A$ and $C$, the majority of the metal braid and bellows convolutions had disappeared. The insulation filling the pipe liner had molten metal in it. When the doors of the shroud were opened, it could be seen that the nut on one of the four bolts holding the end flange of the bellows in place had partially melted. Above this nut (on the top righthand) globules of metal could be seen stuck outside the burner vesse1. The bellows between point $\mathrm{C}$ and the flange was intact, 


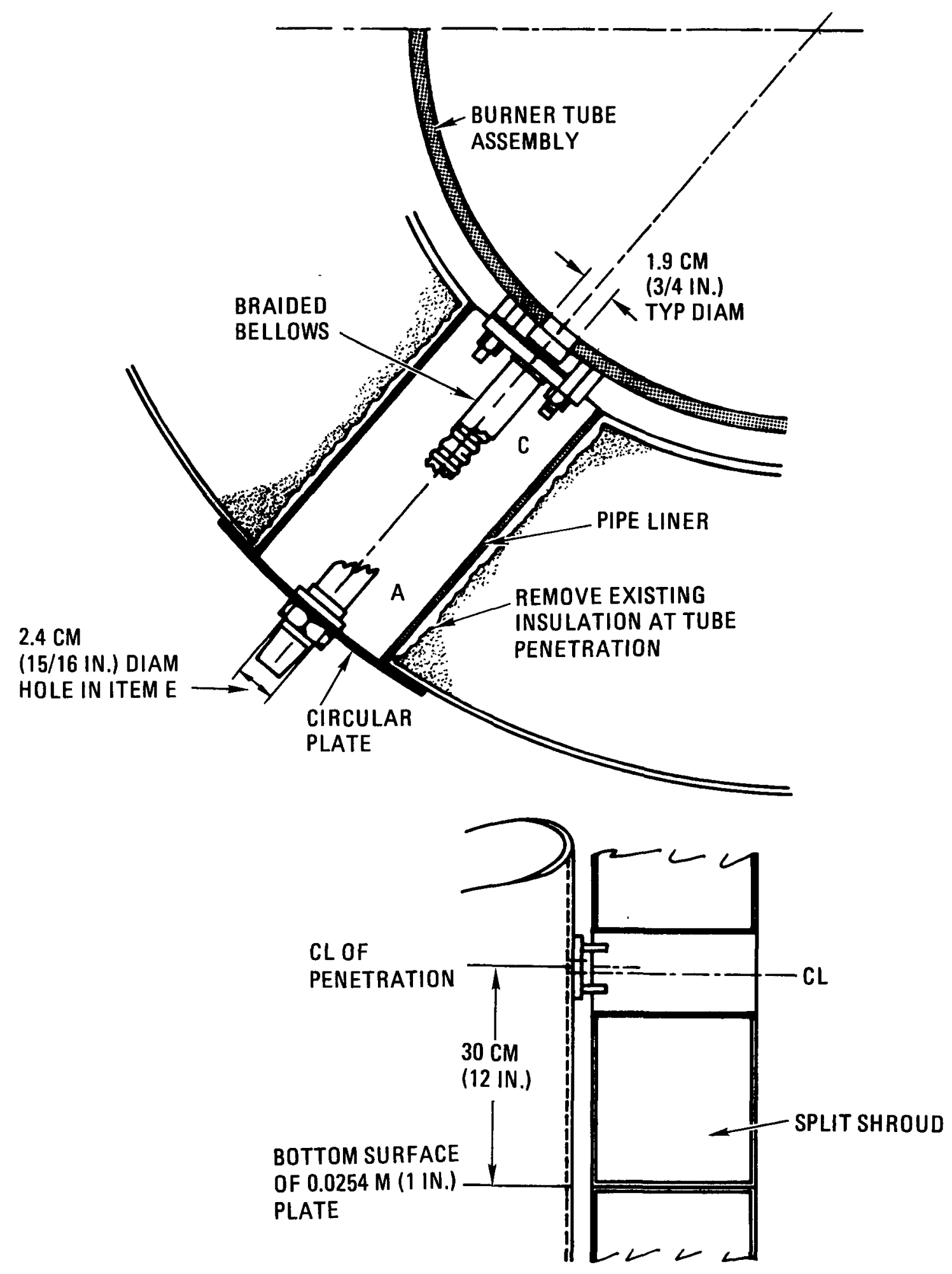

Fig. 15. Detail of penetration through the upper cooling shroud 


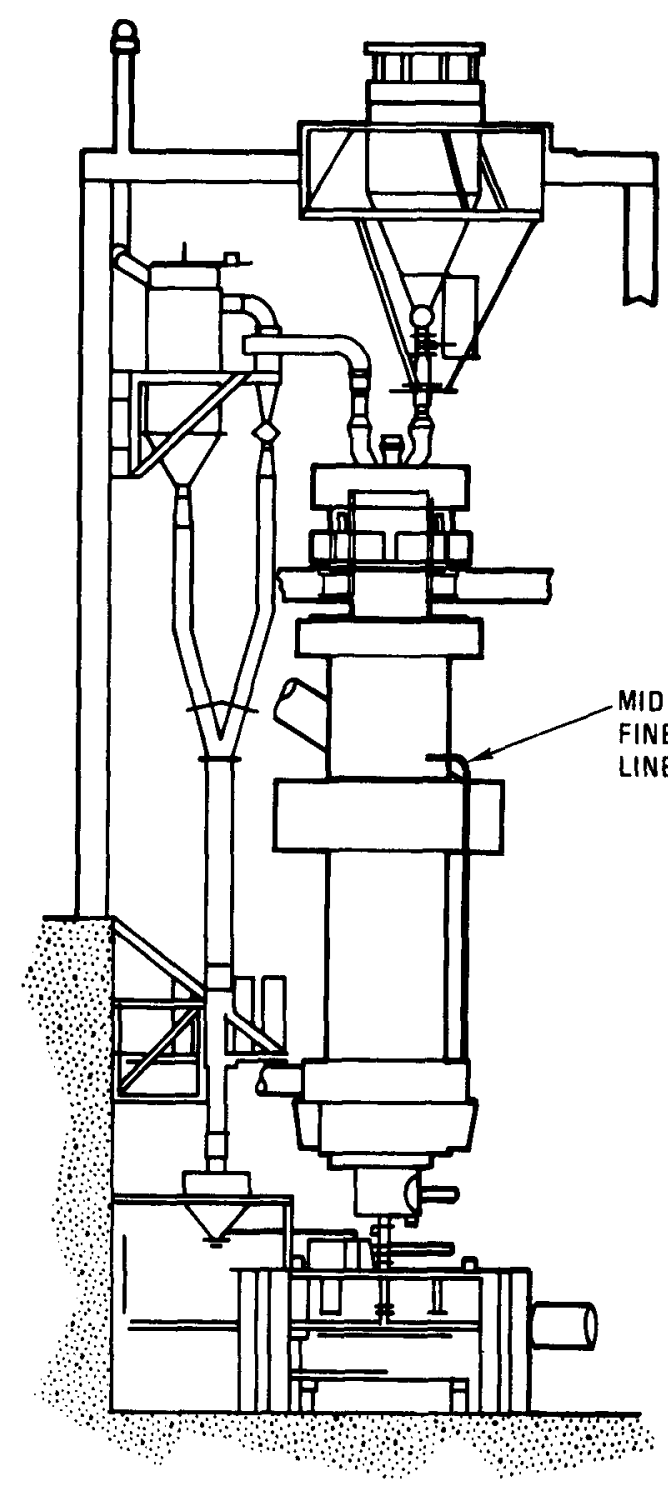

LOOKING EAST

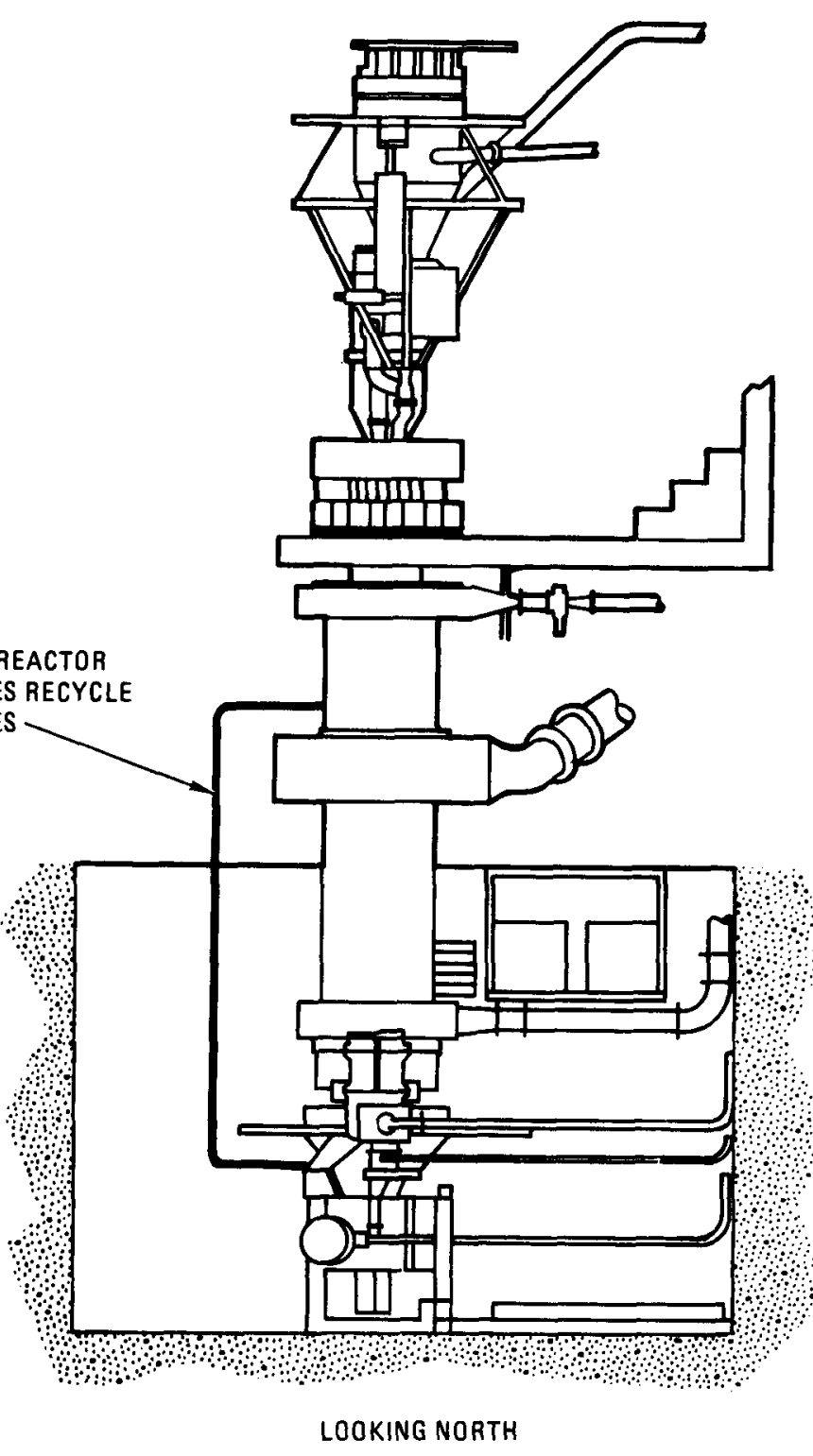

Fig. 16. Overall view of 40-cm primary burner for Runs $D$ and $E$ 
but the metal braid had partially disappeared. Part of the pipe liner had also been burned through. It would appear, therefore, that temperatures in excess of $1200^{\circ} \mathrm{C}$ (approximate melting point of stainless steel) were generated.

At the time of the bellows failure, the combined above-bed $\mathrm{CO}_{2} / \mathrm{O}_{2}$ flow for above-bed pneumatic fines recycle and oxygen addition was approximately $59 \mathrm{~m} / \mathrm{s}$. The composition of the gas passing through the bellows was $67 \%$ oxygen and $33 \%$ carbon dioxide. The temperature of the fines $/ \mathrm{CO}_{2} / \mathrm{O}_{2}$ mixture was estimated to be in the range of $400^{\circ}$ to $500^{\circ} \mathrm{C}$.

A meeting was called to analyze possible causes for the failure and discuss suggestions for improvement. Although several causes for the failure were possible, it was considered most plausible that the substantial gas and fines velocity eroded a hole in the bellows wall (0.13-mm thick) over the approximately $22 \mathrm{~h}$ of operation from Run D and the sequential startup. Several solutions were also devised. The one selected was to replace the bellows with a straight pipe and absorb differential expansion by cutting a slot in the circular plate on the cooling shroud. A similar straight pipe for above-bed pneumatic recycle had been used for approximately $30 \mathrm{~h}$ on a $20-\mathrm{cm}$ primary burner without problems. The solution was implemented and the following operations showed the slot in the circular plate was sufficient to accommodate the differential expansion. Soft insulation added inside the pipe liner prevented noticeable leakage of upper cooling air.

The sequential operation of the primary burner was restarted and burning continued for another $28 \mathrm{~h}$ without problems. At that time, sma1l puffs of fines were seen issuing from the top of the burner thermowell (a $22 \mathrm{~mm}$ o.d. $\times 1.2 \mathrm{~mm}$ wall tube, capped at the bottom). Fines recycle was stopped at this time. Midreactor and vertex $\mathrm{O}_{2}$ were turned off while the opening in the top of the thermowell was plugged with Sauereisen cement. Fines recycle was restarted and full $\mathrm{O}_{2}$ flow rates were regained without leaking, so the run was continued. 
After the last of the crushed product had been fed, an intermittent leak of fines was seen in the area of the pipe $Y$, which joins the two parallel fines hoppers to the common fines recycle transport pipe. Fines recycle was immediately stopped, thus stopping the leak. This incident, alone, would not have curtailed product bed tailburning, even though the fines inventory could not be reduced to minimum levels. However, $2 \mathrm{~h}$ after the last of the crushed blocks had been fed, internal burner thermocouples in the thermowell below the point of midreactor injection indicated they were open or shorted out. The run was immediately terminated as bed temperature monitoring was no longer possible.

Inspection of the pipe $Y$ after the run revealed a $1-\mathrm{mm}$ hole eroded in the downstream leg. The $\mathrm{Y}$ had been contorted (due to manufacture and/or installation), and a ridge in the contorted pipe i.d. had presented a perpendicular face to the erosive fines flow. The recycling fines had eroded the hole through this abrupt edge during the almost $100 \mathrm{~h}$ of cyclic fines transport at $26 \mathrm{~m} / \mathrm{s}$ velocity that the $\mathrm{Y}$ had been in service.

Inspection of the thermowell after the run indicated that the tube had been eroded through by the high velocity fines stream injected perpendicular to the tube. The initial eroded hole (as indicated by the first fines puffs) had grown with the continued operation. The fix had allowed operation to continue well into the tail-burning phase. The eroded hole in the thermowell faced the midreactor penetration inlet, and the hole was opposite to the inlet. Thus, the thermowell tube was subjected to the high velocity (approximately $60 \mathrm{~m} / \mathrm{s})$ oxygen-rich $\left(70 \% \mathrm{O}_{2}\right)$ jet of graphite fines at a temperature of $500^{\circ} \mathrm{C}$ or higher (if fines burning were present).

The thermowell tube, the target for the fines jet, was eventually eroded to destruction on the face nearest to the fines inlet. Ultimate failure of the remaining back wall of the tube was by mechanical flexing created by the fluidized burner bed. 
Sections of the wall of the thermowell were removed longitudinal to the tube axis from regions above and below the eroded hole and from the opposite back wall (see Fig. 17). These sections were prepared for metallurgical examination for evidence of abrasion, mechanical work hardening, and thermal effects.

Metallurgical mounts presented positive proof that (1) there was extensive grain refinement by the impinging jet on the near-side tube o.d. and the back wall tube i.d., (2) substantial material was removed from the near-side tube o.d. for a distance of approximately $8 \mathrm{~mm}$ above and $8 \mathrm{~mm}$ below the abraded hole, and (3) there was no detectable metal removed from the back wall. In addition, there is evidence of melting and solidification of the tube material in the abraded region above the opening. Fig. 18 illustrates and locates these conditions in the thermowell tube.

From the evidence, it was assumed that the high velocity, high temperature jet of graphite fines impinged upon the thermowe11 tube, which had suffered at least a $67 \%$ strength reduction due to the temperature of the tube's environment $\left(900^{\circ} \mathrm{C}\right)$. The jet, by a combination of mechanical abrasion and local melting created two holes astraddle the center of the tube; the two holes eventually joined, substantially reducing the residual tube cross section and destroying the tubular shape. The mechanical flexing of the resultant area by the dynamic fluidized bed of the burner caused the ultimate separation of the thermowell.

A visual examination of the primary burner interior wa11, opposite the fines recycle penetration, revealed no detectable damage.

A 75-W drop light was lowered into the vessel and the surface observed through the top and two burner wall penetration holes. Also, a fiber optics boroscope was inserted through the penetration holes for a close-up look at the interior surfaces. No detectable damage was apparent. There were small pock marks or indentations on the wall surface, but these are potentially characteristic of the surface. Also, a discolored region 


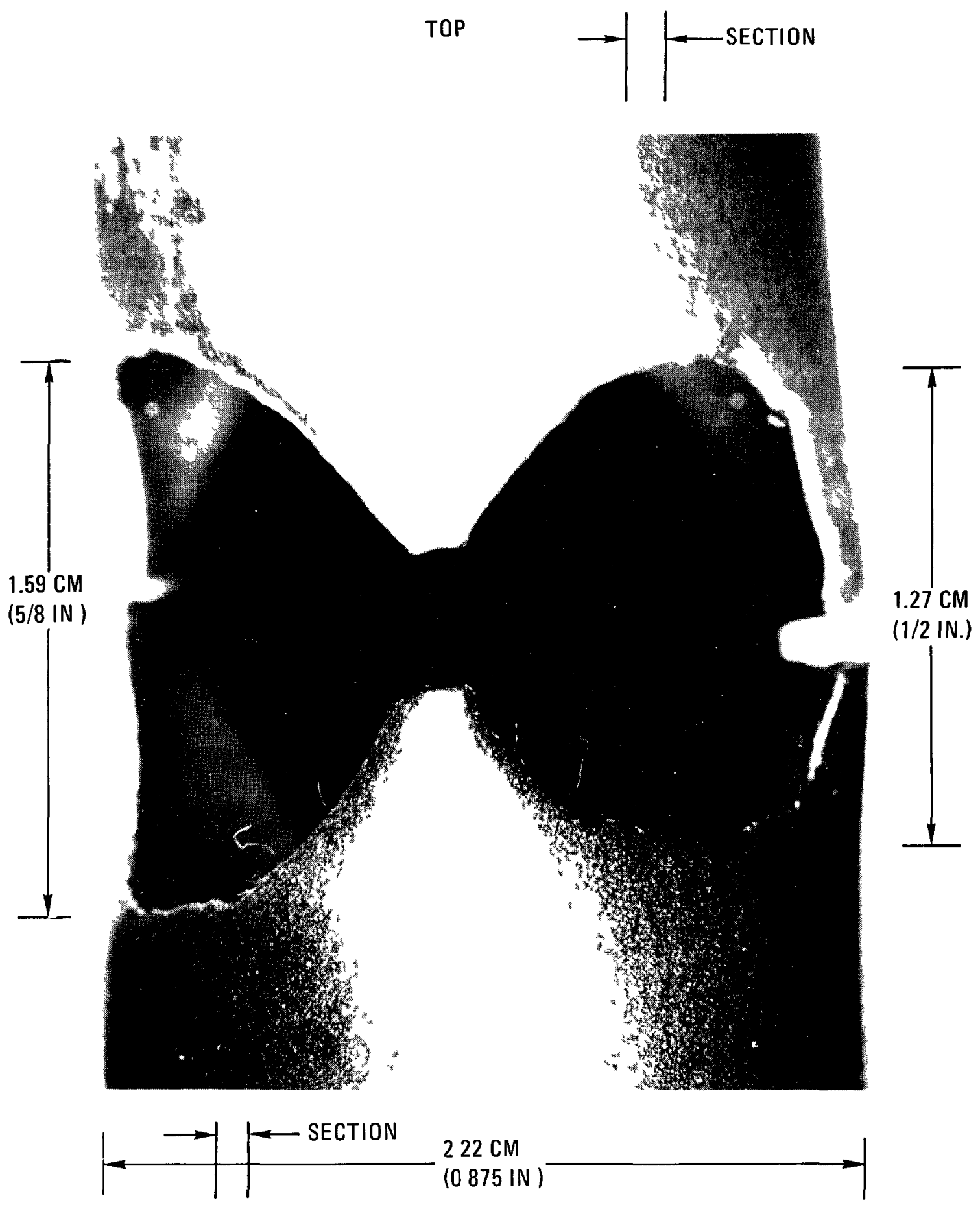

Fig. 17. Thermowel1 wall section 


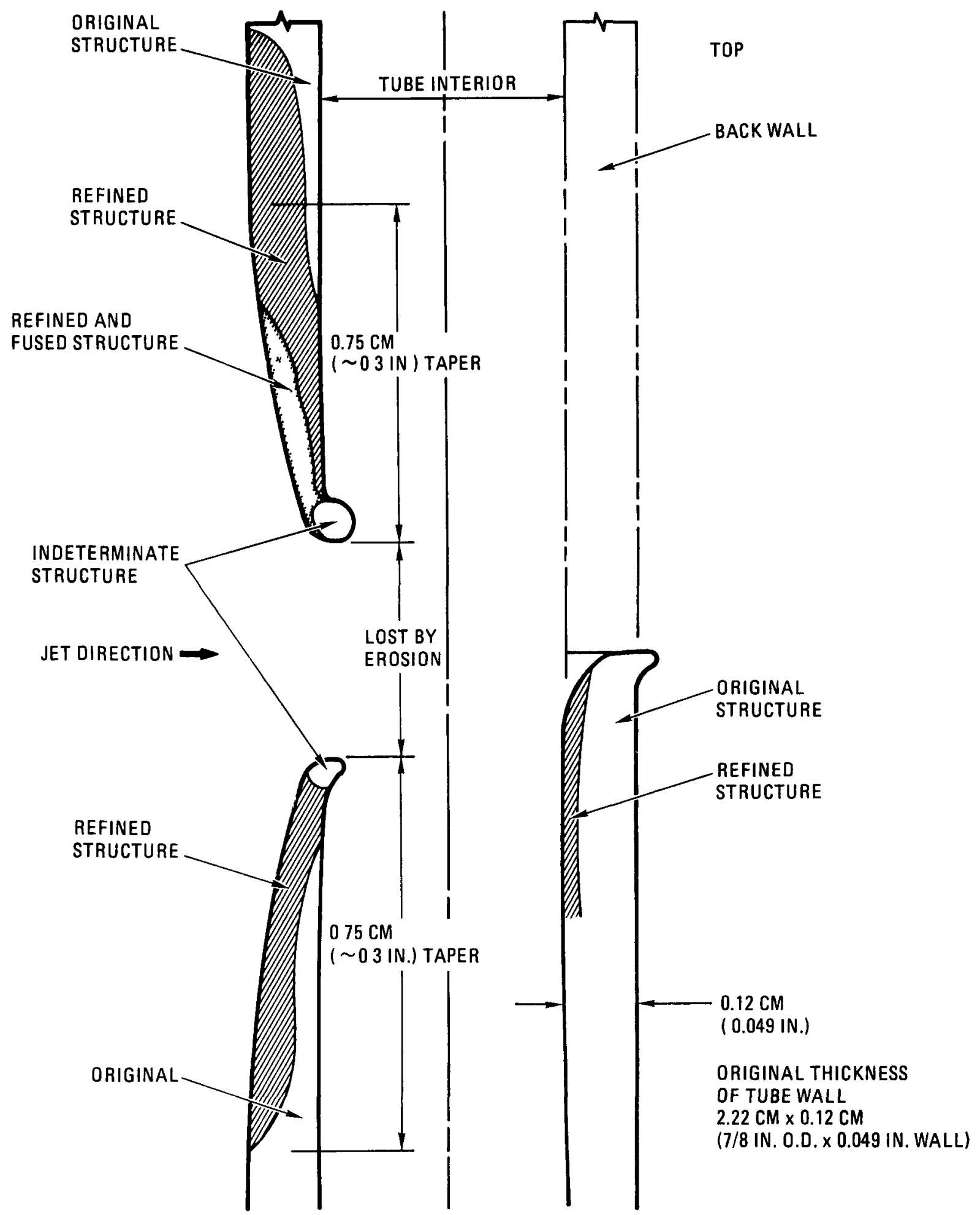

Fig. 18. Thermowell damage, metallurgical evidence 
on the Interior surface opposite to the fines penetration was visible on1y when the drop light was held in just the right position. This discoloration, about $20 \mathrm{~cm}$ ( 4 in.) round in size, was perhaps a slightly worn spot or a surface discoloration; it did not appear to have any measurable depth.

Other than the upsets due to equipment failure, the above-bed fines injection operation using the parallel, pressurized hoppers was similar to that of the prior test (Run D). The two significant operating characteristics, the high transport pressure and the inlet valve binding both reoccurred, but to a lesser degree than in Run $D$. The transport pressure reached $138 \mathrm{kPa}$ (20 psig), but stayed that high for a short time relative to Run D. The transport pressure during the bulk of the run time was 110 to $124 \mathrm{kPa}$ (16 to $18 \mathrm{psig}$ ). The east fines hopper inlet valve was noted binding only once in the second part of the run (see Figs. 19 and 20). The generally smaller mass of recycling fines throughout the sequential operation, relative to Run D, was probably the cause of the reduced operating perturbations.

The fines burning rates were such that the fines inventory was maintained at less than the 15 to $20 \mathrm{~kg}$ capacity of one fines hopper (as indicated by the level probes). This efficiency of fines burning with abovebed injection was similar to a test with in-bed recycle. The midreactor $\mathrm{O}_{2}$ in the sequential operations was increased to $0.25 \mathrm{~m}^{3} / \mathrm{min}(0.17$ vol \% of the total inlet $\mathrm{O}_{2}$ ) well before the plenum $\mathrm{O}_{2}$ ramp was complete. The off-gas $\mathrm{O}_{2}$ was monitored and maintained below approximately 3 vol \% to control the rate of midreactor $\mathrm{O}_{2}$ increase.

In-bed temperature response to fines recycle is shown in Figs, 19 and 20 . The bed temperature cycle induced by the above-bed fines injection was $\pm 15^{\circ} \mathrm{C} \max$ at the beginning of operation and $< \pm 10^{\circ} \mathrm{C}$ for the remainder of the run. The short period of time in which the $\pm 15^{\circ} \mathrm{C}$ cycles occurred was another indicator that the fines mass was low. Any curtailment of above-bed fines recycle caused in-bed temperature increases, 


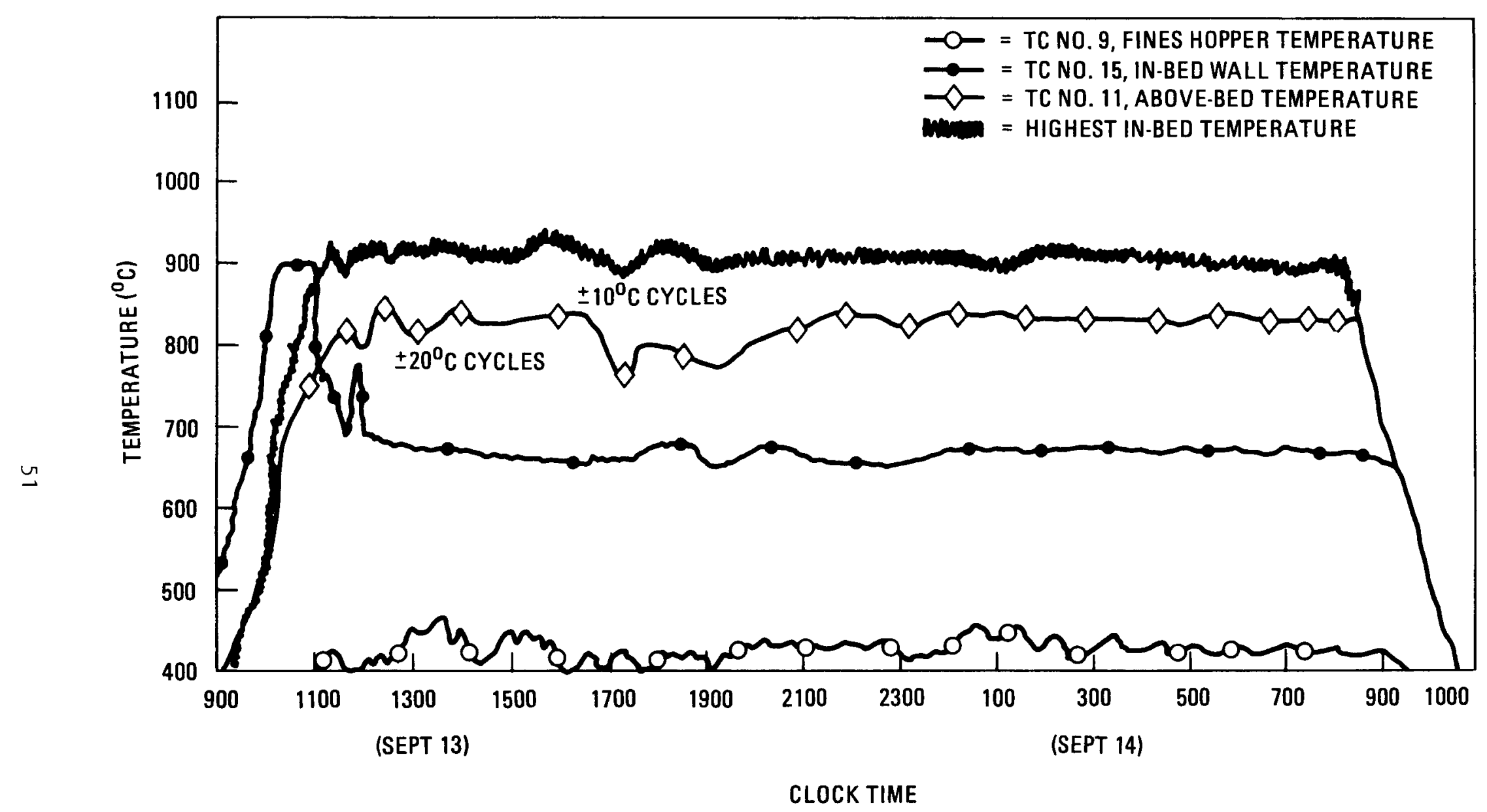

Fig. 19. System temperatures for 40-cm primary burner, Run E, Sept. 13 


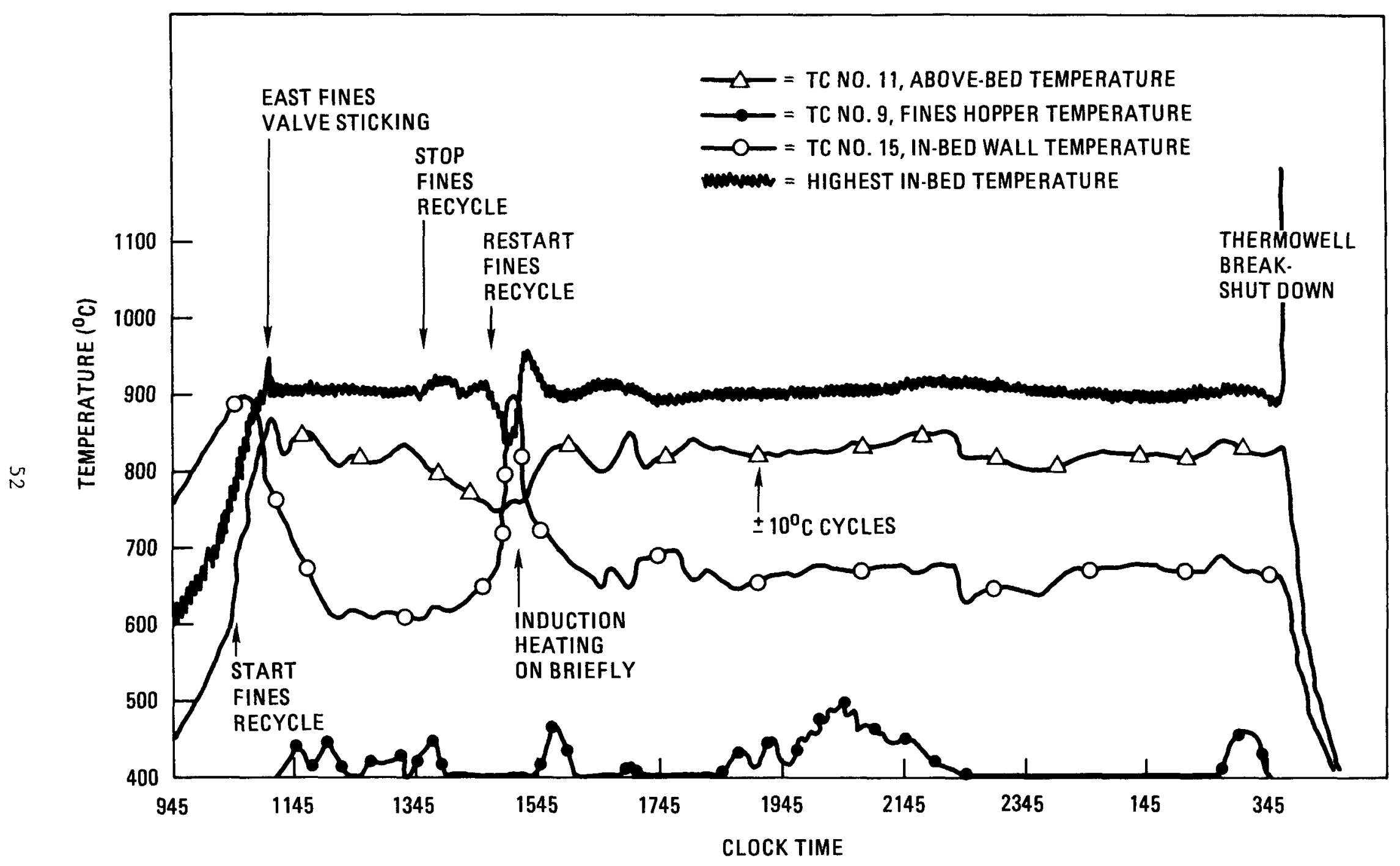

Fig. 20. System temperatures for 40-cm primary burner, Run E, Sept. 20 
demonstrating the heat sink and moderating effect that fines recycle has on the bed.

The above-bed temperature recorded about $0.5 \mathrm{~m}$ above the midreactor $\mathrm{O}_{2}$ /fines inlet is shown as TC (thermocouple) No. 11 on Figs. 19 and 20 . A continuous strip chart record was kept on TC No. 11, whereas all past work had usually only the multipoint to record this above-bed region. The continuous recording revealed that the above-bed temperature also cycles (as much as $\pm 10^{\circ} \mathrm{C}$ in the equilibrium run period) in response to the fines transport cycles.

The recycling fines temperature, shown as TC No. 9 in Figs. 19 and 20 , averaged approximately $420^{\circ} \mathrm{C}$ during the test, peaked at approximately $<500^{\circ} \mathrm{C}$ for a very brief period, and cycled drastically, many times dropping well below $400^{\circ} \mathrm{C}$. These are all indications that the mass of hot fines in the hoppers was generally low, and many times the sensing thermocouple lost contact with the hot fines, thus producing the $<400^{\circ} \mathrm{C}$ cycles.

The wall temperature, given as TC No. 15 in Figs. 19 and 20, did not show a well-defined gradual reduction trend. A fairly smooth reduction to approximately $660^{\circ} \mathrm{C}$ was noted in the first half of the run (Fig. 19), but the second half of the run had significant wall fluctuations (Fig. 19). The fluctuations may be explained by considering that significant changes in the mass of fines recycling changes the bed-to-wall temperature differential, and that fines recycle had to be stopped for $>1 \mathrm{~h}$. This stoppage would have allowed fines mass increases and, thus, would have altered the bed-to-wall temperature differential in subsequent operation. Further fluctuations in the filter pressure differential (Fig. 21) indicate that temporary increases in the circulating fines inventory were occurring. This was attributed to pockets of fines in the feed to the burner. These bursts of additional fines would change the bed-to-wall temperature differential.

The bed-fluidization character of the BISO-TRISO-loaded crushed LHTGR fuel blocks called for a higher gas velocity for initial startup than did 


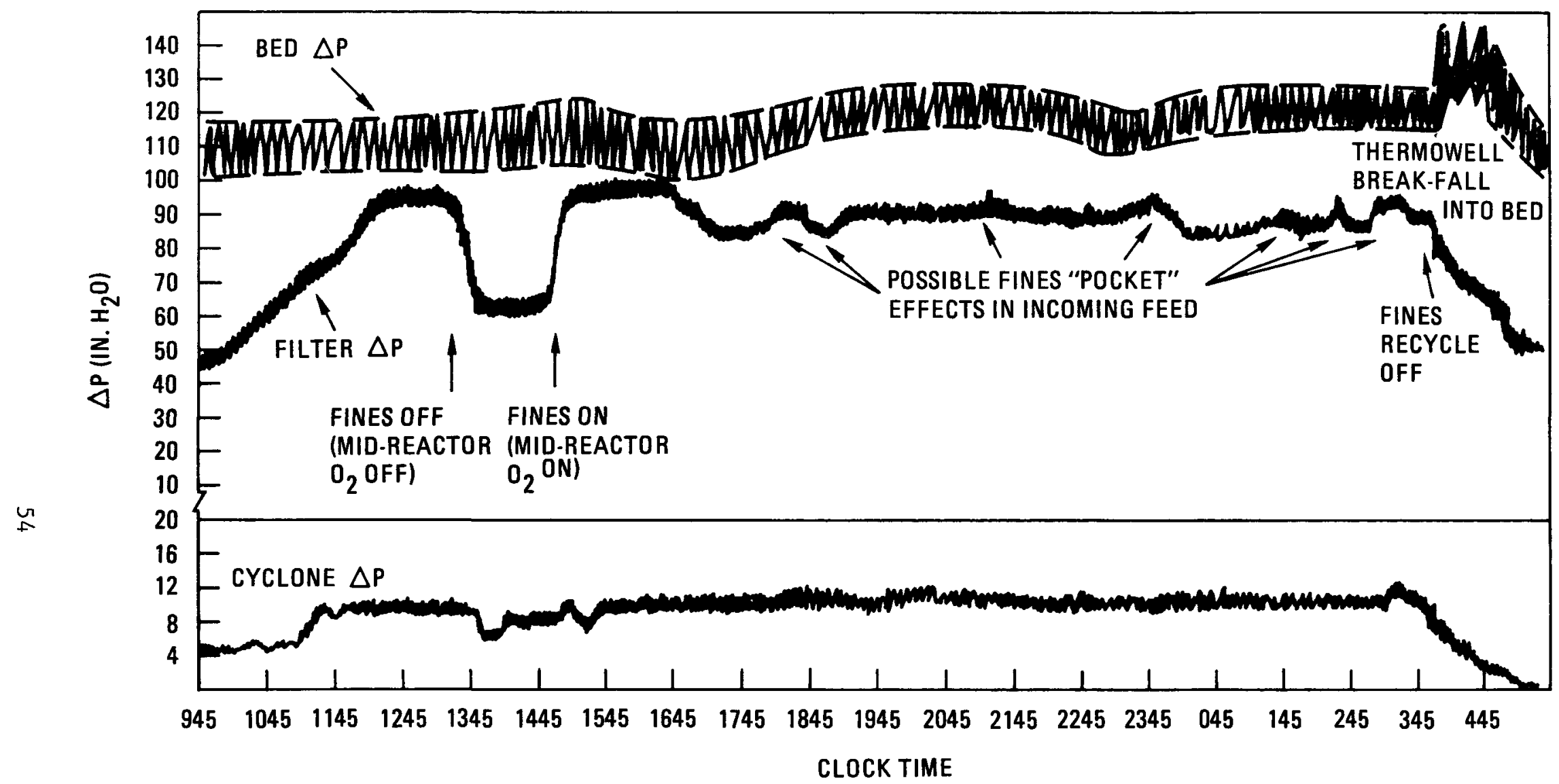

Fig. 21. Bed, filter, and cyclone pressure drops $(\Delta \mathrm{P})$ for $40-\mathrm{cm}$ primary burner, Run E, Sept. 20 
a crushed graphite/BISO-TRISO particle mixed bed. A gas velocity well in excess of $0.43 \mathrm{~m} / \mathrm{s}$ was required to yield isothermal startup bed temperatures. The bed temperature differential was as high as $75^{\circ} \mathrm{C}$ in the earliest portion of the heatup, when bed temperatures were $4400^{\circ} \mathrm{C}$ and superficial velocities $<0.61 \mathrm{~m} / \mathrm{s}$. The high velocity was required only in the initial fresh-feed bed startup. Normal velocities were used in subsequent startups of higher particle concentration beds.

The bed temperature differential during combustion was $<15^{\circ} \mathrm{C}$, indicating excellent fluidization quality at the $1.1 \mathrm{~m} / \mathrm{s}$ operating superficial velocity. No agglomerates of fuel particles were found in the product bed.

The cooling air requirements (Figs. 22 and 23) showed an increase as the run progressed.

The $\mathrm{CO}$ and $\mathrm{O}_{2}$ off-gas concentrations are plotted in Figs. 24 and 25. $\left(\mathrm{CO}_{2}\right.$ may be obtained by difference to a total of $100 \%$.)

The relation between off-gas co cyclic spikes with the cycling fines recycle was apparent. When fines recycle was stopped, off-gas CO was abruptly reduced. This effect was much less significant in midrun than in the tailburning period. The in-bed burning must account for a larger portion of the $\mathrm{CO}$ concentration when the carbon level is high than when the carbon level is low.

The level of $\mathrm{O}_{2}$ in the burner off-gas was noted to begin increasing slightly and to cycle between 1 and 3 vol \%, much the way that the co vol \% cycles with fines flow cycles. The $\mathrm{O}_{2}$ returned to zero vol \% concurrent with indications that a large mass of fines had entered with the final feed quantity. Apparently, the circulating fines mass was being depleted to a quantity marginal in consuming all of the midreactor $\mathrm{O}_{2}$.

The final $\mathrm{O}_{2}$ blip occurred immediately after fines recycle was stopped, and before midreactor $\mathrm{O}_{2}$ was reduced. Subsequent reductions of 


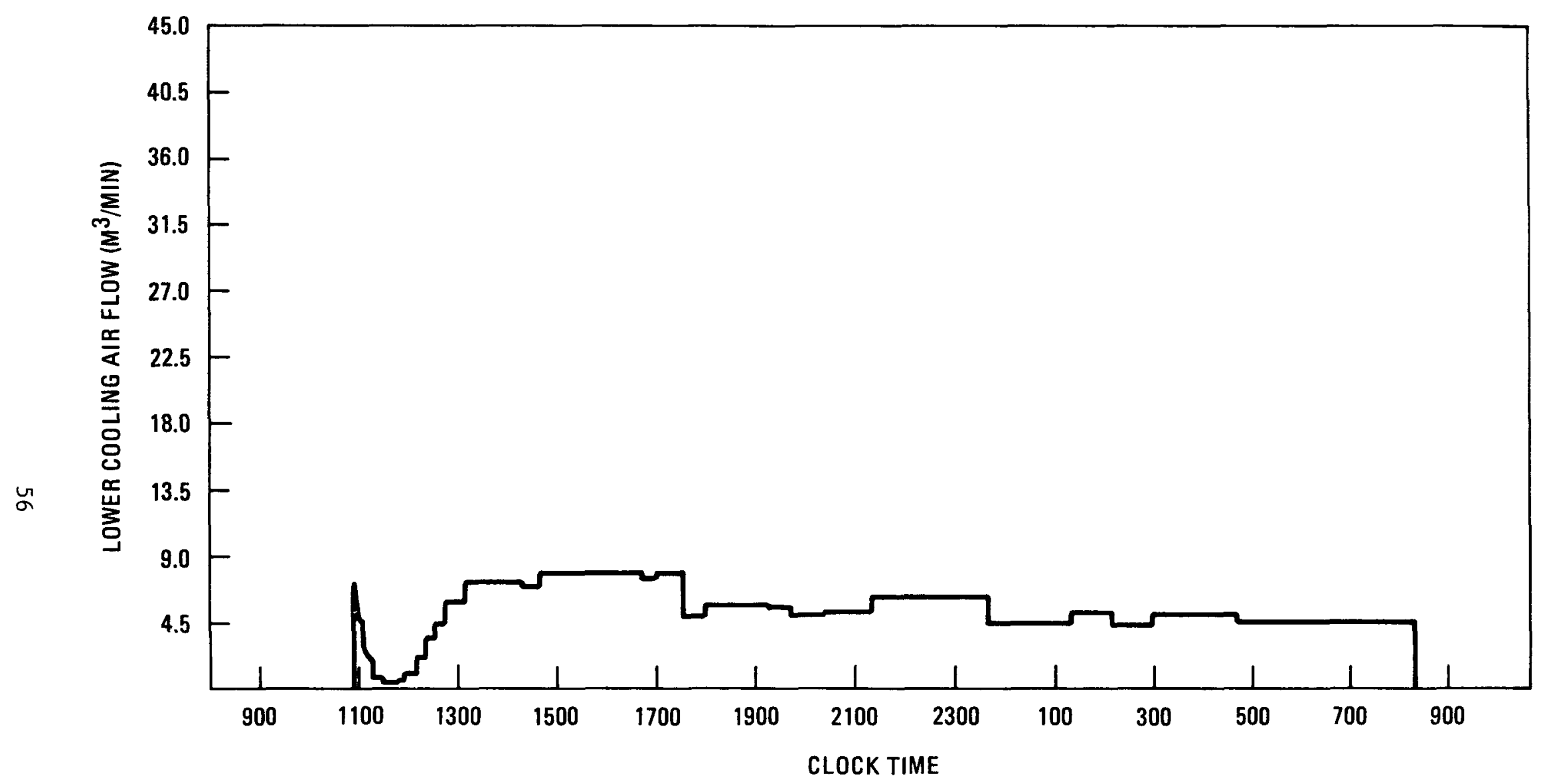

Fig. 22. Cooling air flow for 40-cm primary burner, Run E, Sept. 13 


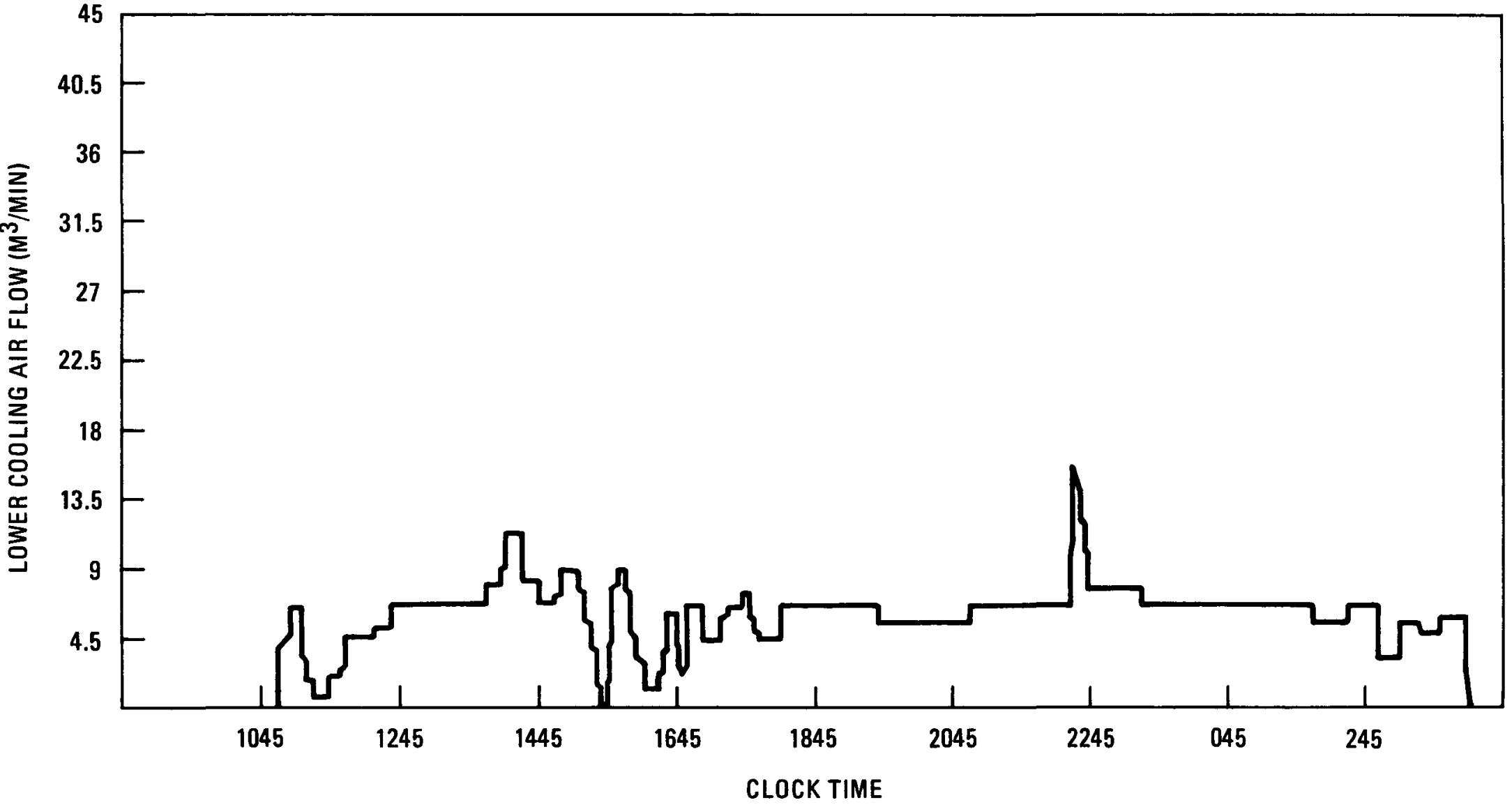

Fig. 23. Cooling air flow for 40-cm primary burner, Run E, Sept. 20 


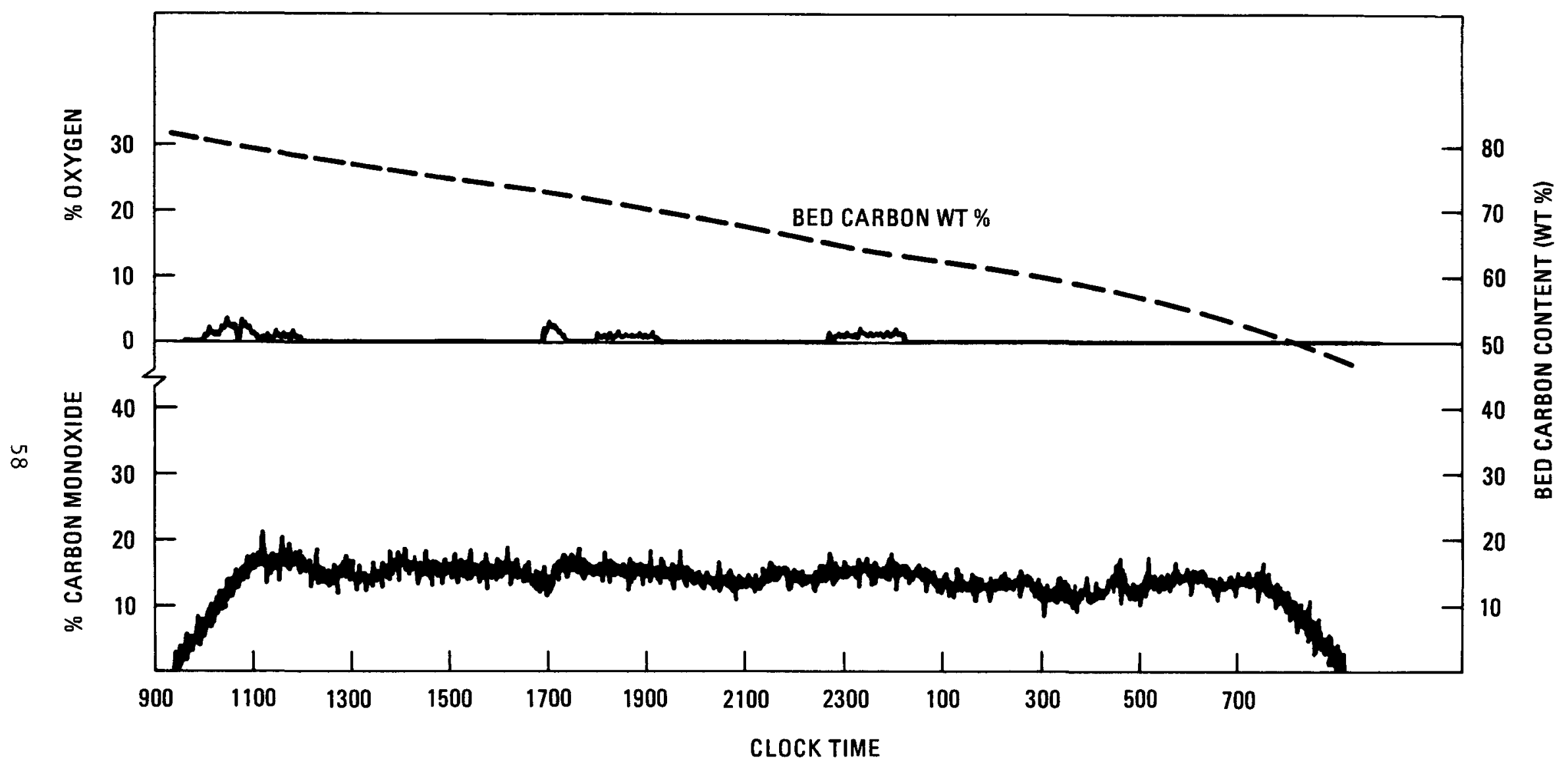

Fig. 24. Off-gas concentration for 40-cm primary burner, Run E, Sept. 13 


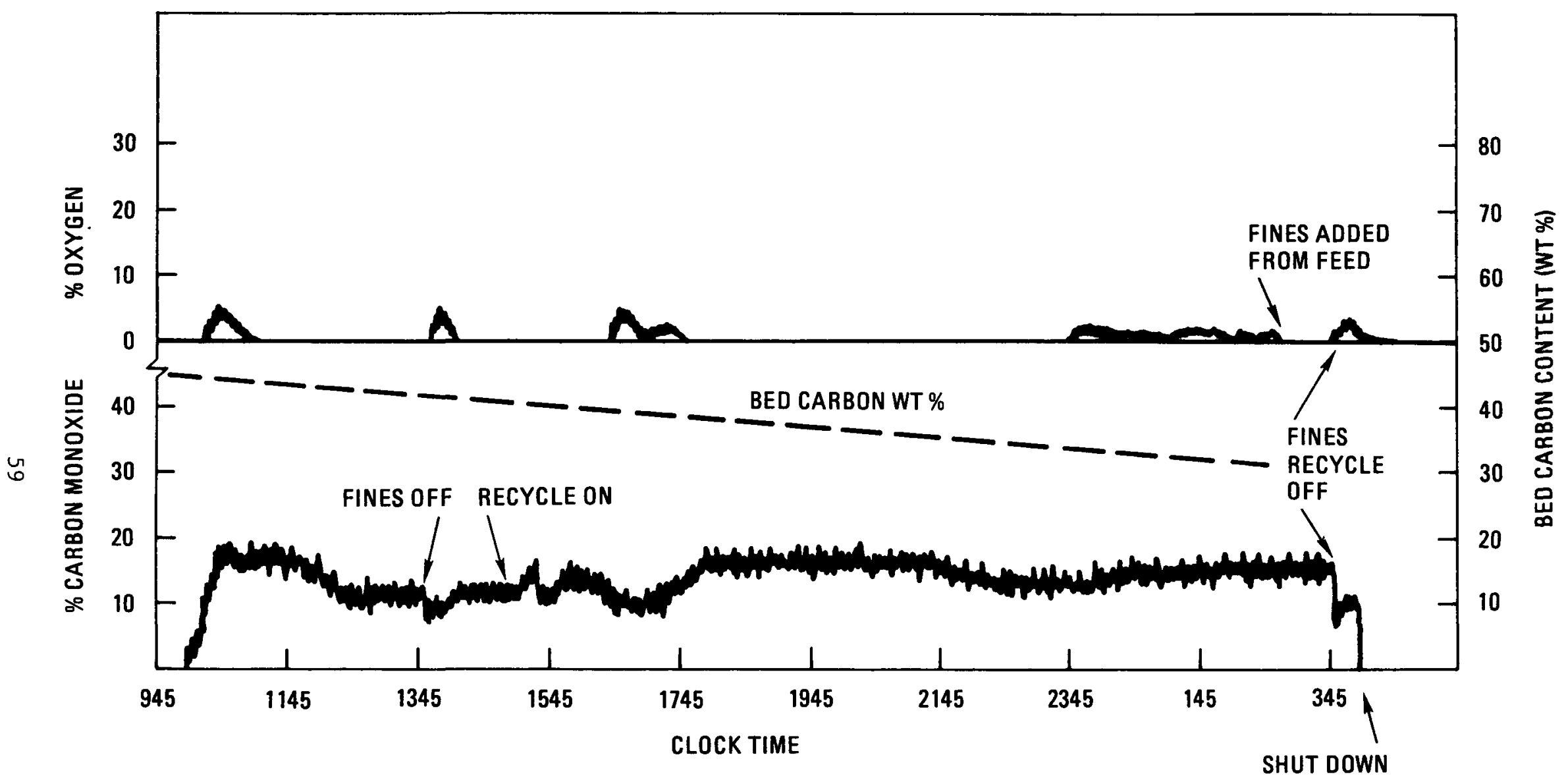

Fig. 25. Off-gas concentration for 40-cm primary burner, Run E, Sept. 20 
midreactor $\mathrm{o}_{2}$ from 0.25 to $0.10 \mathrm{~m}^{3} / \mathrm{min}$ kept the off-gas $\mathrm{o}_{2}<3$ vol $\%$, and avoided an above-bed fines flash-burn situation.

The final product included five portions: (1) the product bed pneumatically transported out of the bottom of the burner (the lower portion of the final bed), (2) the product bed vacuumed out through the top of the burner (after the broken thermowell plugged the bottom burner vertex outlet), (3) the plenum material pounded through the gas distributor perforations during the slugging bed operation, (4) the final fines hopper material, and (5) the 11 fines samples taken throughout the test.

The material balance data is summarized in Tables 7 and 8 . The most significant data indicates the following:

1. The higher particle breakage in sequential operations relative to Run $D$ may be due to two basic differences between the operations: (1) Run D was $<24 \mathrm{~h}$, while the sequential operation lasted $>40 \mathrm{~h}$. The additional time for slugging operation attrition action certainly would add to particle breakage; (2) Run D fuel particles were not put through a crusher and the additional handling associated with crushing. Although the burner breakage values were adjusted for breakage of particles in the feed, the quantity of feed particles that were weakened (though not broken) may be somewhat higher and would add to subsequent breakage within the burner system.

2. The TRISO portion of the overall breakage was higher than the BISO breakage. Table 8 shows that 15.2 wt \% of TRISO particles removed were broken, compared to only 5.2 wt \% of the BISO particles.

3. Although the final bed was not tailburned and total carbon content was approximately $30 \mathrm{wt} \%$, the carbon coatings on the particles were virtually all burned away. The carbon remaining 
TABLE 7

MATERIAL BALANCE SUMMURY FOR $40-\mathrm{cm}$ PRIMARY BURNER TEST

\begin{tabular}{|c|c|c|c|c|}
\hline Item $^{(a)}$ & $\begin{array}{c}\begin{array}{c}\text { Top } \\
\text { Product } \\
\text { Bed }\end{array} \\
\end{array}$ & & $\begin{array}{c}\text { Bottom } \\
\text { Product } \\
\text { Bed } \\
\end{array}$ & Comments \\
\hline \multicolumn{5}{|c|}{ Combustibles Balance } \\
\hline $\begin{array}{l}\text { 1. Carbon in }(\mathrm{kg}) \\
\text { 2. Product bed; }+850(\mathrm{~kg}) \\
\text { 3. Product bed; }-850,+355(\mathrm{~kg}) \\
\text { 4. Product bed; }-355(\mathrm{~kg}) \\
\text { 5. P1enum; +355(b) (kg) } \\
\text { 6. P1enum; }-355(\mathrm{~b})(\mathrm{kg}) \\
\text { 7. Final fines hopper; }+355(\mathrm{~kg}) \\
\text { 8. Final fines hopper; }-355(\mathrm{~kg}) \\
\text { 9. Total carbon unburned (kg) } \\
\text { 10. Carbon out in fines samples (kg) }\end{array}$ & $\begin{array}{c}67.66 \\
18.18 \\
3.336\end{array}$ & $\begin{array}{c}2015.37 \\
\\
0.65 \\
1.64 \\
0.0415 \\
11.900 \\
104.707 \\
17.129 \\
\end{array}$ & $\begin{array}{l}0.03 \\
1.29 \\
0.019\end{array}$ & Note most of the carbon +850 graphite chunks \\
\hline \multicolumn{5}{|c|}{ Noncombustibles Balance } \\
\hline 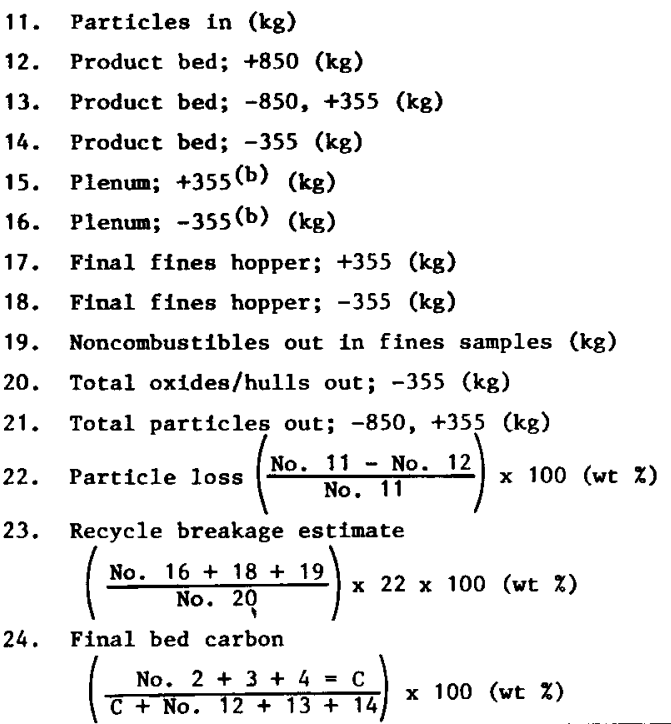 & $\begin{array}{r}4.14 \\
91.32 \\
7.064\end{array}$ & $\begin{array}{c}157.97 \\
5.04 \\
0.0097 \\
2.81 \\
0.764 \\
17.289 \\
358.95 \\
8.7 \\
4.33\end{array}$ & $\begin{array}{r}1.89 \\
109.65 \\
1.611\end{array}$ & $\begin{array}{l}407.6 \text { in crushed blocks, } 14.6 \text { pulled for samples } \\
\text { Top of product bed, } 70 \% \text { TRISO material } \\
\text { Bottom of product bed, } 93 \% \text { BISO material } \\
93 \% \text { BISO material } \\
93 \% \text { BISO material } \\
99 \% \text { TRISO material } \\
99 \% \text { TRISO material } \\
85 \% \text { TRISO material } \\
\begin{array}{l}14+16+18+19 \\
13+15+17\end{array}\end{array}$ \\
\hline
\end{tabular}

(a) 850 and 355 are micron screen sizes.

(b) Includes a small unknown quantity of transported product bed (bottom). 
TABLE 8

PARTICLE BREAKAGE DISTRIBUTION BASED UPON URANIUM, THORIUM ANAIYSSIS, 40-cm RUN

\begin{tabular}{|c|c|c|c|c|c|c|c|c|c|}
\hline & $\begin{array}{l}\quad \text { Top } \\
\text { Product } \\
\text { Bed (a) }\end{array}$ & $\begin{array}{l}\text { Bottom } \\
\text { Product } \\
\text { Bed (a) }\end{array}$ & Plenum & $\begin{array}{c}\text { Fines } \\
\text { Hoppers }\end{array}$ & $\begin{array}{c}\text { Total } \\
\text { Breakage } \\
(\mathrm{kg})\end{array}$ & $\begin{array}{c}\text { Total } \\
\text { Particles } \\
\text { Out } \\
(\mathrm{kg}) \\
\end{array}$ & $\begin{array}{c}\text { Total } \\
\text { Breakage } \\
\text { (wt \%) }\end{array}$ & $\begin{array}{l}\text { Broken } \\
\text { In-Feed } \\
\text { (wt \%) }\end{array}$ & $\begin{array}{l}\text { Broken in } \\
\text { Burner and } \\
\text { Transport } \\
\text { (wt \%) }\end{array}$ \\
\hline $\begin{array}{r}\text { Broken BISO particles (kg) } \\
\text { (Thorium equilvalent) (b) }\end{array}$ & 0.76 & 2.57 & 15.34 & 0.21 & 18.88 & 286.5 & 6.6 & 0.9 & 5.7 \\
\hline $\begin{array}{c}\text { Broken TRISO particles (kg) } \\
\text { (Uranium equivalent) }(\mathrm{c})\end{array}$ & $8.27(d)$ & $6.13(d)$ & 4.74 & 2.46 & 21.60 & 96.2 & 22.5 & 7.3 & 15.2 \\
\hline Total out & -- & -- & -- & -- & 40.48 & 382.7 & $10.6^{(\mathrm{e})}$ & -- & - \\
\hline
\end{tabular}

(a) Top bed includes breakage due to pneumatic transport out through vacuum system; bottom bed includes breakage due to pneumatic transport out through vertex line partially blocked by the broken thermowell.
(b) Thorium $g$ in fraction $\div 0.88$.
(c) Uranium $g$ in fraction $\div 0.18$.
(d) More than $40 \%$ of this fraction leached out of partially cracked $+355-\mu m$ particles.
(e) Versus the 8.7 wt \% particle loss calculated from sieve results (Table 7). 
in the bed was predominately chunks of graphite. Most of this graphite was found floating in the top product bed, as shown in Table 7.

4. The final fines inventory found in the two hoppers (not tailburned) totalled only $12 \mathrm{~kg}$ of carbon fines, but also contained $2.8 \mathrm{~kg}$ of oxides/hulls (99\% TRISO material). This $19 \mathrm{wt} \%$ noncombustible oxide/hull content built up over the run as shown in fines sample history (see Fig. 26).

5. The distribution of BISO and TRISO material indicated that the TRISO particles float on top of the BISOs at the top of the bed (see comments on items 12 through 14, Table 7). Hence, the material pounded into the plenum is predominately BISO (see items 15 and 16, Table 7). The fines material was virtually all from TRISO particle breakage (99\%, see ttems 17 and 18, Table 7), an indication of the higher magnitude of TRISO breakage and the location of the TRISO particles in the upper bed zones from which generated fines easily elutriate.

The primary burner product removal system was operated only under upset burner conditions during the sequential test. Burner product $(152 \mathrm{~kg})$ at approximately $400^{\circ} \mathrm{C}$ was conveyed from the burner at a very low feed rate. (Actual feed rate could not be ascertained due to the upset.) The broken thermowell inside the burner caused the reduced feed rate and ultimately obstructed the burner outlet entirely. Samples were collected both at the entrance to the conveying line and below the product bunker. Comparison of the two samples in Table 9 illustrates the damage inflicted by conveying fuel particles at elevated temperature and low feed rate.

The increase in fertile particle breakage was $0.18 \%$. This is not considered a significant change. The increase in fissile particle breakage was $1.3 \%$; however, the fissile material made up only $1.2 \%$ by weight of the total heavy metal in each sample. Since this portion of the total 


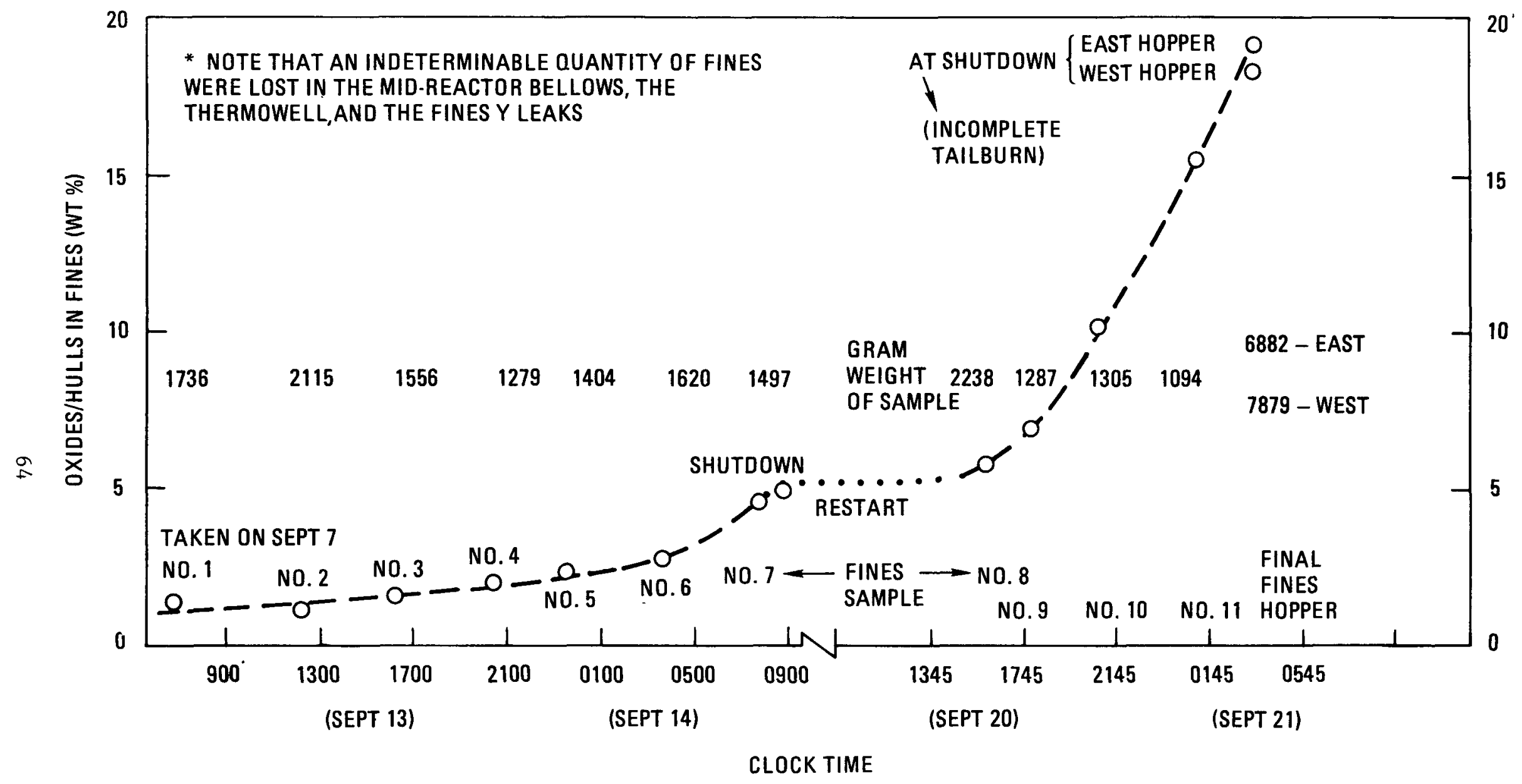

Fig. 26. Recycle fines oxide/hull content and fines sample history for 40-cm primary burner, Run E 
TABLE 9

PARTICLE BREAKAGE IN PRIMARY BURNER PRODUCT, BEFORE AND AFTER TRANSPORT (a)

\begin{tabular}{l|c|l}
\hline Particle & $\begin{array}{c}\text { Broken } \\
(\%)\end{array}$ & Description \\
\hline Fertile & 2.33 & Before transport \\
Fissile & 90.7 & \\
Fertile & 2.51 & After transport at $400^{\circ} \mathrm{C}$ \\
Fissile & 92.0 & \\
\hline
\end{tabular}

(a) Burner product consisted of $152 \mathrm{~kg}$ of material removed through the burner outlet under upset condition. The broken burner thermowell was lodged in the outlet, restricting the flow rate. 
burner product contained so little fissile material, the fissile breakage results cannot be considered as representative.

The primary burner product removal system performed well during sequential operation. The variable position knifegate valve controls have been improved since the tests and a new variable speed blower has been installed for the system. Controls for the new blower will be installed in the control room.

The Tube and Screw (TS) sampler, located beneath the primary burner product bunker, presented operational problems. The rotating tube had a tendency to bind on the transfer piping through which it extends. The sampler was partially disassembled and was coaxed occasionally during sampling cycles. A new transition pipe, designed to eliminate the possibility of tube binding, has been fabricated and installed since the sequential test.

The tube sampler, located beneath the variable position knifegate valve at the conveying system entrance, functioned successfully. The sampler orifice had been enlarged and relocated to improve sampler performance for the sequential test.

\subsection{FUEL PARTICLE AIR CLASSIFICATION OPERATIONS}

The air classification of primary burner products from the pilot plant sequential operations consisted of three separate tests in the engineering scale zigzag air classification system. The objective of each of these tests was to determine the extent to which the separation of the LHTGR TRISO-BISO fuel particles could be achieved using normal classifier operating parameters. The feed materials were somewhat atypical due to the forced premature shutdown of the primary burner, which left greater than normal quantities of unburned graphite fuel element material, and due to the inability to normally discharge and pneumatically transport the entire feed to the classifier feed hopper. 
For that portion of the primary burner product which was transported, the classifier feed system functioned normally at an average conveying gas velocity of $15 \mathrm{~m} / \mathrm{s}$ and feed rate of $0.29 \mathrm{~kg} / \mathrm{s}$. Higher feed rates and lower velocities produced unreliable transport characteristics. The observed system pressure drop corresponded within $10 \%$ of that predicted. The pressure drop correlation is plotted on Fig. 13.

In a11 three tests, a classifying gas velocity of $6.0 \mathrm{~m} / \mathrm{s}$ was used. Each of the three feed materials was fed to the classifier using $100 \%$ capacity of the vibratory feeder. Identical operating conditions had been previously tested with BISO-TRISO particles with good results. Samples were taken of the BISO stream (underflow) and the TRISO stream (overhead) using identical laboratory Vezin samplers installed in the piping above the product collection bunkers. The material collected in the filter chamber was discharged at the end of each test and split to obtain a suitable sample. Each of the samples was burned back to remove the residual carbon and analyzed for thorium and uranium content.

The individual results for all three classifier tests and a summation of the materials recovered in the BISO streams (underflow) and TRISO streams (overhead and filter chamber) are given in Table 10.

\subsubsection{Initial Bed Removal}

Initially a portion of the primary burner product was removed using the pneumatic transport system to transport the material to the classifier feed hopper. The discharge was interrupted by a blockage in the primary burner outlet, and the remainder of the material was removed by other means. The first classifier test was made using $113.7 \mathrm{~kg}$ of this initial bed removal material as feed. As expected, this material was predominantly broken and whole BISO kernels (110.1 $\mathrm{kg}$ or $96.8 \%$ ) due to segregation in the burner. The total carbon content of this feed was $1.1 \%$ $(1.3 \mathrm{~kg})$. The average feed rate throughout this test was approximately $2.0 \mathrm{~kg} / \mathrm{min}$ (see Table 10). 
TABLE 10

CLASSIFIER SEOUENTIAL TESTS

\begin{tabular}{|c|c|c|c|c|c|c|c|c|c|c|c|c|c|c|c|c|c|}
\hline \multirow[b]{3}{*}{ Material } & \multirow{2}{*}{\multicolumn{3}{|c|}{ Sample }} & \multicolumn{7}{|c|}{ Sample After Burn-Back } & \multirow{2}{*}{\multicolumn{3}{|c|}{ Heavv Metala }} & & & \multirow{3}{*}{$\begin{array}{l}\text { Th in } \\
\text { TRISO } \\
\text { Stream } \\
(\%)\end{array}$} & \multirow{3}{*}{$\begin{array}{c}\text { U In } \\
\text { TRISO } \\
\text { Stream } \\
(\%)\end{array}$} \\
\hline & & & & & & & Burnable & & & & & & & & & & \\
\hline & $\begin{array}{l}\text { Total } \\
\text { Wt } \\
(\mathrm{kg})\end{array}$ & $\begin{array}{c}\text { Carbon } \\
\text { Wt } \\
(\mathrm{kg})\end{array}$ & $\begin{array}{c}\text { Burnable } \\
\text { Carbon } \\
(\%)\end{array}$ & $\begin{array}{l}\text { Total } \\
\text { Wt } \\
(\mathrm{kg})\end{array}$ & $\begin{array}{l}\text { Th } \\
\text { Wt } \\
(\mathrm{kg})\end{array}$ & $\begin{array}{c}\mathrm{v} \\
\mathrm{Wt} \\
(\mathrm{kg})\end{array}$ & $\begin{array}{c}\text { Carbon } \\
\text { Wt } \\
(\mathrm{kg})\end{array}$ & $\begin{array}{l}\text { Th } \\
(\%)\end{array}$ & $\begin{array}{c}u \\
(\%)\end{array}$ & $\begin{array}{c}\text { Burnable } \\
\text { Carbon } \\
(\%)\end{array}$ & $\begin{array}{l}\text { Total } \\
\text { Wt } \\
(\mathrm{kg})\end{array}$ & $\begin{array}{l}\text { Th } \\
(\%)\end{array}$ & $\begin{array}{c}U \\
(\%)\end{array}$ & 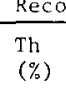 & $\begin{array}{c}U \\
(\%)\end{array}$ & & \\
\hline
\end{tabular}

Inıtıal Bed Removal, Classifier Test No 1 Feed $113^{-} \mathrm{kg}(1 \mathrm{n} 2 \mathrm{t} 1 \mathrm{al}$ bed removal materıal) Av feed rate $u 2$ Okg/min.

BISO (broken and whole kernels) $1101 \mathrm{~kg}(960 \%)$

\begin{tabular}{|c|c|c|c|c|c|c|c|c|c|c|c|c|c|c|c|c|c|}
\hline $\begin{array}{l}\text { BISO stream } \\
\text { Underflow }\end{array}$ & 1084 & 11 & 10 & 1073 & 943 & 12 & 11 & 279 & 11 & 846 & 955 & 487 & 13 & 974 & 800 & -- & 13 \\
\hline $\begin{array}{l}\text { TRISO stream } \\
\text { Overhead }\end{array}$ & 4.8 & 0.1 & 30 & 47 & 24 & 02 & 01 & 513 & 33 & 77 & 26 & 923 & 77 & 25 & 133 & 923 & -- \\
\hline Filter & 05 & 20.1 & 82 & 05 & 01 & 01 & 01 & 129 & 127 & 77 & 02 & 500 & 500 & 01 & 6.7 & 50.0 & -- \\
\hline Total & 1137 & 1.3 & 11 & 1125 & 968 & 15 & 13 & 860 & 13 & & 983 & 785 & 15 & 1000 & 100.0 & $\begin{array}{ll}893 \\
\end{array}$ & 13 \\
\hline
\end{tabular}

Plenum Matertals, Classifier Test No 2 . Feed $1633 \mathrm{~kg}(1258 \mathrm{~kg}$ plenum material $+375 \mathrm{~kg} 1 \mathrm{mitzal}$ bed removal material). Av feed rate. $22.4 \mathrm{~kg} / \mathrm{m} ı \mathrm{n}$.

\begin{tabular}{|c|c|c|c|c|c|c|c|c|c|c|c|c|c|c|c|c|c|}
\hline $\begin{array}{l}\text { BISo stream } \\
\text { Underflow }\end{array}$ & 149.8 & 15 & 10 & 1483 & 1249 & 10 & 15 & 842 & 07 & 375 & 1359 & 992 & 08 & 980 & 476 & -- & 08 \\
\hline $\begin{array}{c}\text { TRISO stream } \\
\text { Overhead }\end{array}$ & 11.3 & 1.6 & 14.5 & 9.7 & 25 & 10 & 16 & 362 & 100 & 400 & 35 & 714 & 286 & 20 & 47.6 & 71.4 & -- \\
\hline Filter & 22 & 0.9 & 410 & 1.3 & 01 & 01 & 09 & 109 & 107 & 225 & 02 & 500 & 50.0 & $\cap 1$ & 4.8 & 500 & -- \\
\hline Total & 163.3 & 4.0 & 2.5 & 1593 & 1275 & 2.1 & 4.0 & 800 & 13 & & 1296 & $78+$ & 16 & 1001 & 1000 & 70.3 & 0.8 \\
\hline
\end{tabular}

Final Bed Removal, Classifier Test No. 3. Feed $1022 \mathrm{~kg}$ (material from final bed removal). Av feed rate. $\sim 1.1 \mathrm{~kg} / \mathrm{m} ı \mathrm{n}$.

\begin{tabular}{|c|c|c|c|c|c|c|c|c|c|c|c|c|c|c|c|c|c|}
\hline $\begin{array}{l}\text { BISO stream } \\
\text { Underflow }\end{array}$ & 24.1 & 25 & 18.8 & 216 & 17.3 & 01 & 25 & 800 & 07 & 281 & 174 & 794 & 06 & 896 & 09 & -- & 0.6 \\
\hline $\begin{array}{l}\text { TRISO stream } \\
\text { Overhead }\end{array}$ & 69.0 & 5.0 & 7.2 & 640 & 1.9 & 10.0 & 5.0 & 30 & 15.7 & 562 & 119 & 16.0 & 840 & 98 & 88.5 & 16.0 & -- \\
\hline Fliter & 9.1 & 1.4 & 15.5 & 77 & 01 & 12 & 14 & 09 & $1>9$ & 157 & 13 & 77 & 923 & 05 & 106 & 7.7 & -- \\
\hline Total & 102.2 & 8.9 & 87 & 93.3 & 193 & 113 & 89 & 207 & 121 & & 306 & 631 & 369 & 79.9 & 1000 & 152 & 06 \\
\hline \multicolumn{18}{|c|}{ Classifier Summary. } \\
\hline $\begin{array}{l}\text { BISO stream } \\
\text { Underflow }\end{array}$ & 282.3 & 5.1 & 1.8 & 277.2 & 236.5 & 2.3 & 5.1 & 85.3 & 08 & 359 & 2388 & 990 & 10 & 971 & 15.4 & -- & 1.0 \\
\hline $\begin{array}{l}\text { TRISO stream } \\
\text { Overhead }\end{array}$ & 85.1 & 6.7 & 7.9 & 78.4 & 6.8 & 112 & 6.7 & 8.7 & 14.3 & 47.2 & 18.0 & 378 & 62.2 & 2.8 & 75.2 & 378 & -- \\
\hline F11ter & 11.8 & 2.4 & 20.3 & 9.5 & 0.3 & 1.4 & 2.4 & 32 & 147 & 169 & 17 & 176 & 824 & 01 & 94 & 176 & -- \\
\hline Total & 379.2 & 14.2 & 3.7 & 365.1 & 243.6 & 149 & 14.2 & 667 & 4.1 & & 2585 & 942 & 5.8 & 1000 & 1000 & 36.0 & 1.0 \\
\hline
\end{tabular}




\subsubsection{Plenum Materials}

After complete shutdown of the primary burner, the material which had fallen through the gas distributor plate holes into the plenum was removed by vacuum. The second classifier test was made using $125.8 \mathrm{~kg}$ of this material and $37.5 \mathrm{~kg}$ of the initial bed removal material for a $163.3 \mathrm{~kg}$ total. Again, as expected, this material was disproportionately broken and whole BISO kernels $(145.0 \mathrm{~kg}$ or $88.8 \%)$. The total carbon content of this feed was $2.5 \%(4.0 \mathrm{~kg})$. The average feed rate throughout this test was approximately $2.4 \mathrm{~kg} / \mathrm{min}$ (see Table 10).

\subsubsection{Fina1 Bed Removal Material}

The remainder of the material in the burner tube was removed by vacuum from the top of the burner. After removal, the material was screened to separate the coarse $(+869-\mu \mathrm{m})$ and fine $(-412-\mu \mathrm{m})$ fractions from the particle range material ( -869 to $+412-\mu$ m fraction). The average feed rate throughout the test was approximately $1.1 \mathrm{~kg} / \mathrm{min}$.

The screening was done to remove as much of the large and fine unburned fuel element graphite as practical from the particles for classification. The third classifier test was made using $102.2 \mathrm{~kg}$ of the particle range material from the final bed removal material. As expected, this material contained a disproportionally smaller quantity of broken and whole BISO kernels $(21.9 \mathrm{~kg}$ or $21.4 \%)$, because of the earlier removal of the segregated BISO kernels. The total carbon content of this feed was $8.7 \%(8.9 \mathrm{~kg})$ (see Table 10$)$.

\subsubsection{Classified Product Summation}

The calculated combined total feed of $379.2 \mathrm{~kg}$ for the three tests contained a BISO to TRISO particle percentage of $77 \%$ to $23 \%$, respectively. These percentages were reasonably close to the $74 \%$ to $26 \%$ BISO to TRISO percentages expected from fully burned-back LHTGR fuel elements, even through they were not present in these percentages in any of the individual 
tests. The carbon content of the total feed was $3.7 \%$ or $14.2 \mathrm{~kg}$, with the highest being $8.7 \%$ in the final bed material after removal of the fine and coarse materials (see Table 10).

\subsubsection{Discussion}

Past classification tests had indicated that under identical operating conditions to those used for the sequential classifications, the crossover of BISO particles into the TRISO stream was a function of broken BISO particles in the feed. Microscopic examination of various mesh fractions of the TRISO stream product showed that the BISO particles present were broken and substantiated this earlier observation. Crossover in all three of the sequential operation classifications was substantially higher than in the tests using blends of particles. This could be expected since the quantity of broken particles was substantially higher due to processing and pneumatic transport. However, recovery of BISO particles from the feeds which were predominately BISO particles was greater than from the feed which was predominantly TRISO particles (i.e., $97.4 \%$ and $98 \%$ recovery from initial bed and plenum materials, respectively, and $89.6 \%$ recovery from the final bed mate ial). However, it is not certain at this time whether these products contained more or less broken particles or if the recovery was improved by a mechanism related to the feed composition. Future tests are planned using products from the sequential tests to study classification of feeds containing broken particles.

Microscopic examination of the BISO particles recovered in the BISO stream showed them to be coated with what appeared to be a fine dust deposit. This deposit was present after burnback, and it is unlikely that it is residual carbon. Since no whole TRISO particles were clearly identifiable in this product, and the uranium from broken TRISO particles would quickly form a fine powder in the burner, it is possible that at least a portion of the uranium crossover is in the form of dust adhering to the BISO kernels. Future tests will be utilized to more clearly define the mechanism of uranium crossover. 


\subsubsection{Material Balances}

The weight of the feed materials for each test was obtained from load cells on the feed hopper. At the conclusion of each test, the weight of the underflow and overhead products was obtained from load cells on their respective product collection hoppers. The materials collected in the filter vessel were discharged after blowing back of the filters to dislodge accumulated dusts, and weighed on a balance. The material balances are given in Table 11. In all tests, a positive material unaccounted for (MUF) was obtained. The total MUF for all three tests was $3.04 \%$, which is in excess of that desired for accountability purposes. Because of the consistent positive MUF and its magnitude, the load cells are probably somewhat in error.

\subsection{FUEL PARTICLE CRUSHING AND SECONDARY BURNING OPERATIONS}

Classified fissile particles from the material removed from the primary burner final bed were conveyed with an average conveying gas velocity of $15 \mathrm{~m} / \mathrm{s}$ and a feed rate of $0.1 \mathrm{~kg} / \mathrm{s}$. The observed transport system pressure drop correlated very closely with that predicted, as shown in Fig. 13. The total feed material weight for the secondary burner run was $49.3 \mathrm{~kg}$. Composition of $9 \mathrm{wt} \%$ carbon, $6 \mathrm{wt} \% \mathrm{ThO}_{2}$, and $85 \mathrm{wt} \%$ TRISO WAR particles. This was crushed through the double-roll crusher to yield a crushed feed size distribution as shown in Fig. 27.

The gravity pneumatic feeder added the crushed feed material to the burner in $4 \mathrm{~min}$.

\subsubsection{Burning Operations}

Pertinent operating variables during the burner run are shown in Figs. 28 through 31. These include burner temperatures, inlet gas flows, outlet gas composition, and cooling air flows. From these, it can be seen that fluid bed heating to $600^{\circ} \mathrm{C}$ ignition temperature took $50 \mathrm{~min}$. This 
TABLE 11

MATERIAL BALANCE AIR CLASSIFIER SEQUENTIAL TESTS

\begin{tabular}{l|c|c|c|c}
\hline & $\begin{array}{c}\text { Feed } \\
\text { Wt } \\
(\mathrm{kg})\end{array}$ & $\begin{array}{c}\text { Total } \\
\text { Product } \\
\text { Wt } \\
(\mathrm{kg})\end{array}$ & $\begin{array}{c}\text { Gain }(+) \text { or } \\
\text { Loss }(-) \\
(\mathrm{kg})\end{array}$ & $\begin{array}{c}\text { MUF } \\
(\% \text { of feed })\end{array}$ \\
\hline Initial bed removal & 108.3 & 113.7 & 5.4 & 4.99 \\
P1enum material & 165.3 & 167.6 & 2.3 & 1.39 \\
Final bed removal & 98.6 & $\frac{102.2}{3.6}$ & $\frac{3.65}{11.3}$ & 3.04 \\
Totals & 372.2 & 383.5 & 11.3 \\
\hline
\end{tabular}




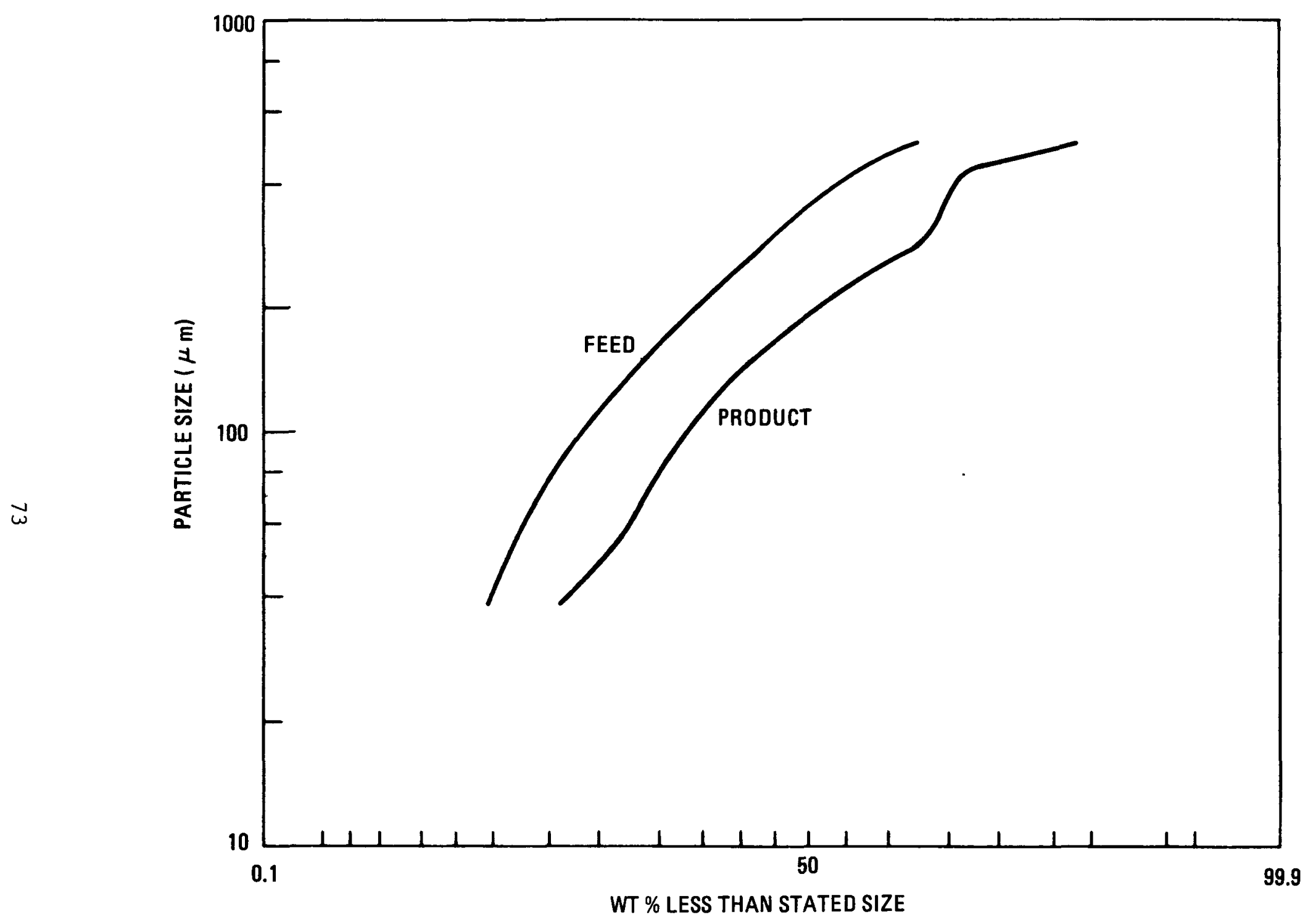

Fig. 27. 20-cm secondary burner, size distribution of feed and product from sequential operation run 


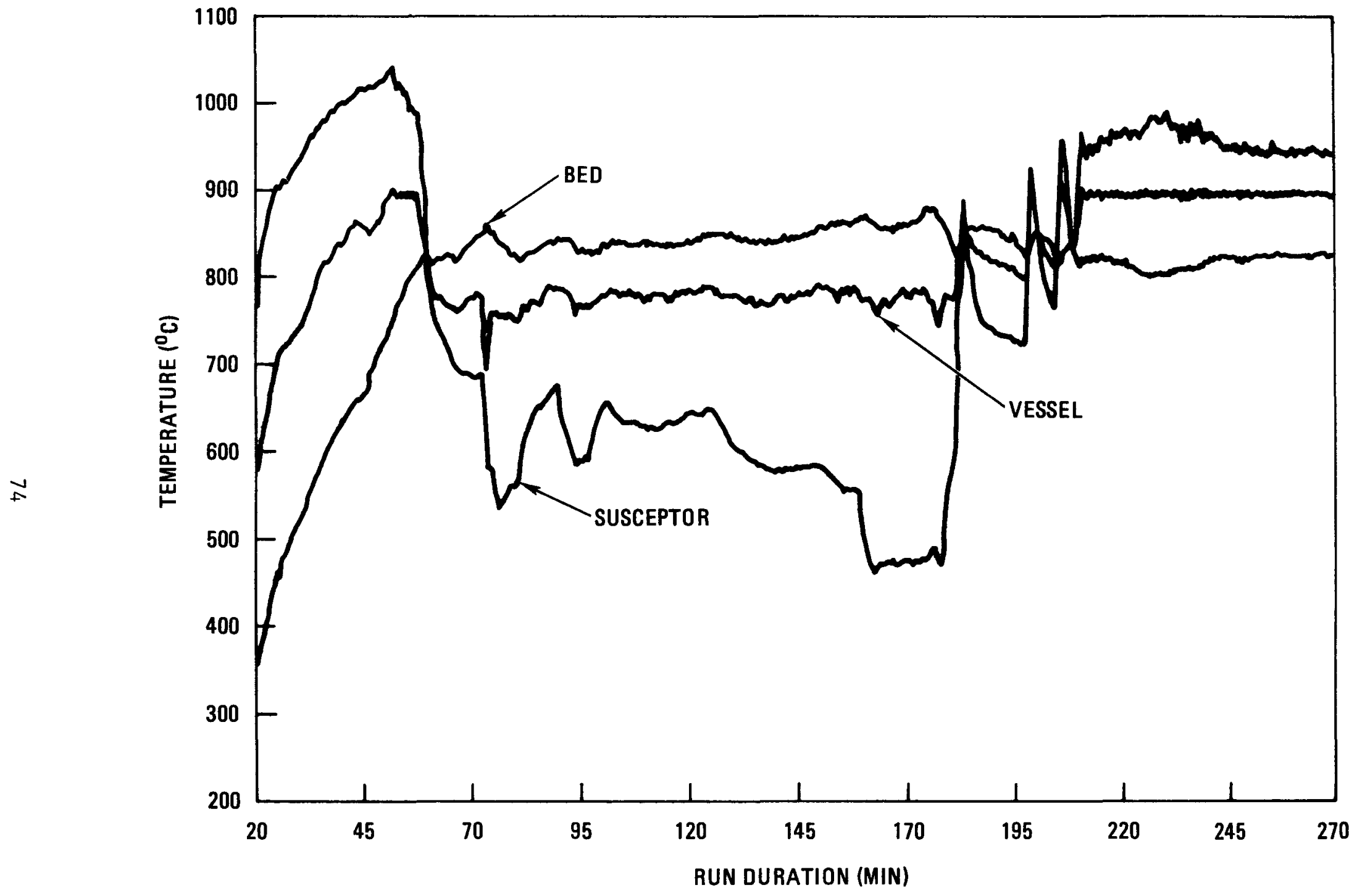

Fig. 28. 20-cm secondary burner, sequential run, burner temperatures 


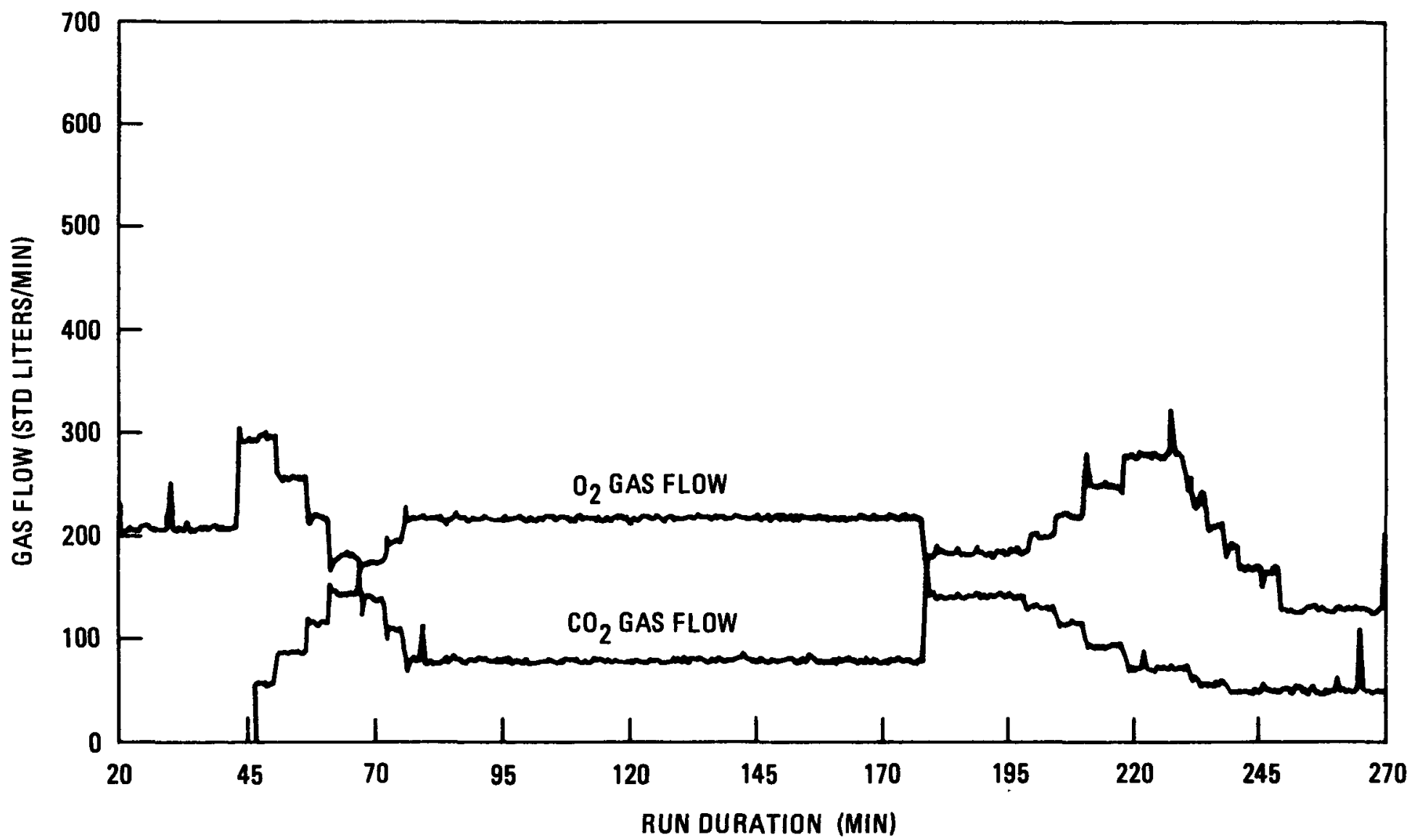

Fig. 29. 20-cm secondary burner, sequential run, $\mathrm{O}_{2}$ and $\mathrm{CO}_{2}$ gas flows 


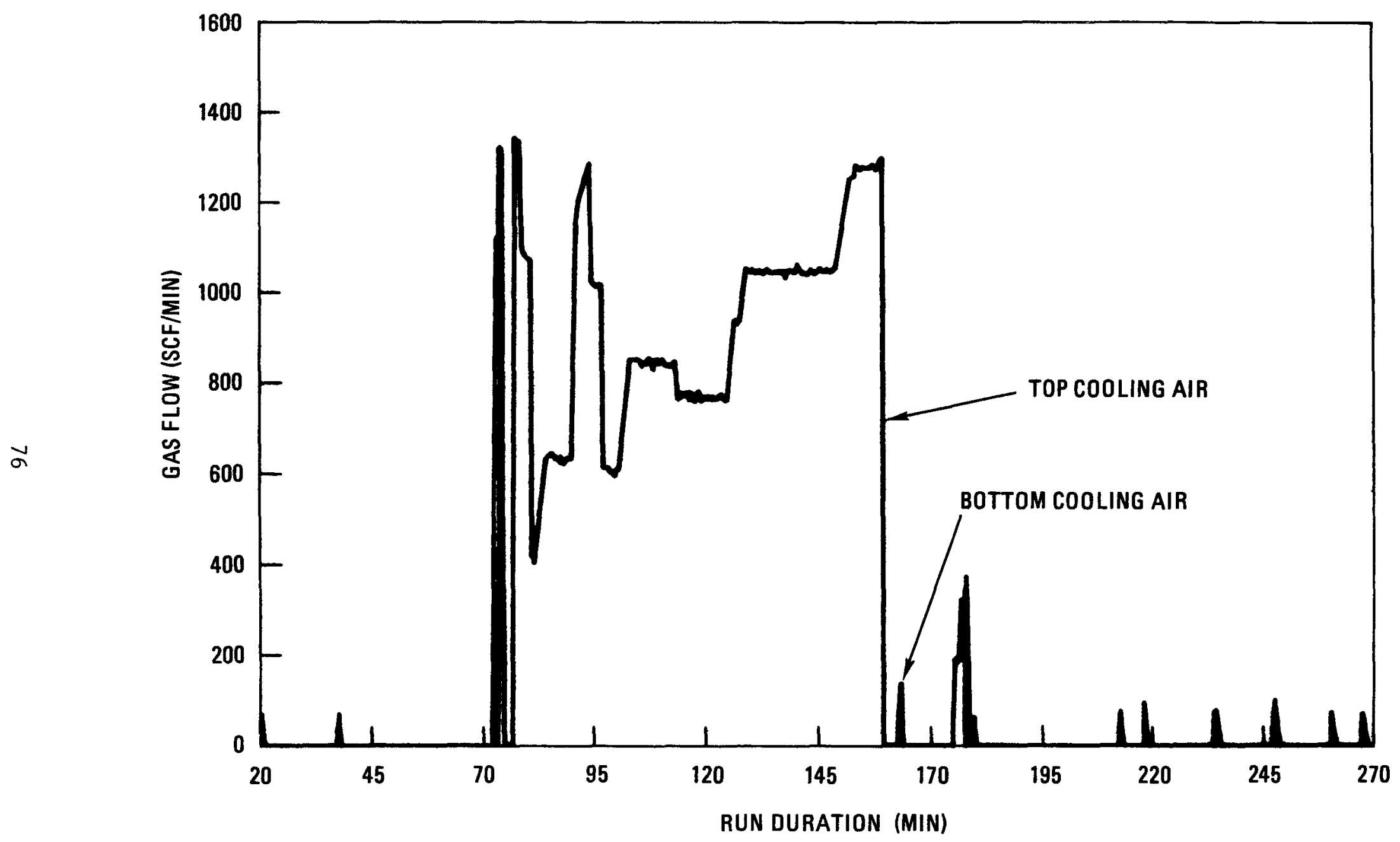

Fig. 30. 20-cm secondary burner, sequential run, cooling air flows 


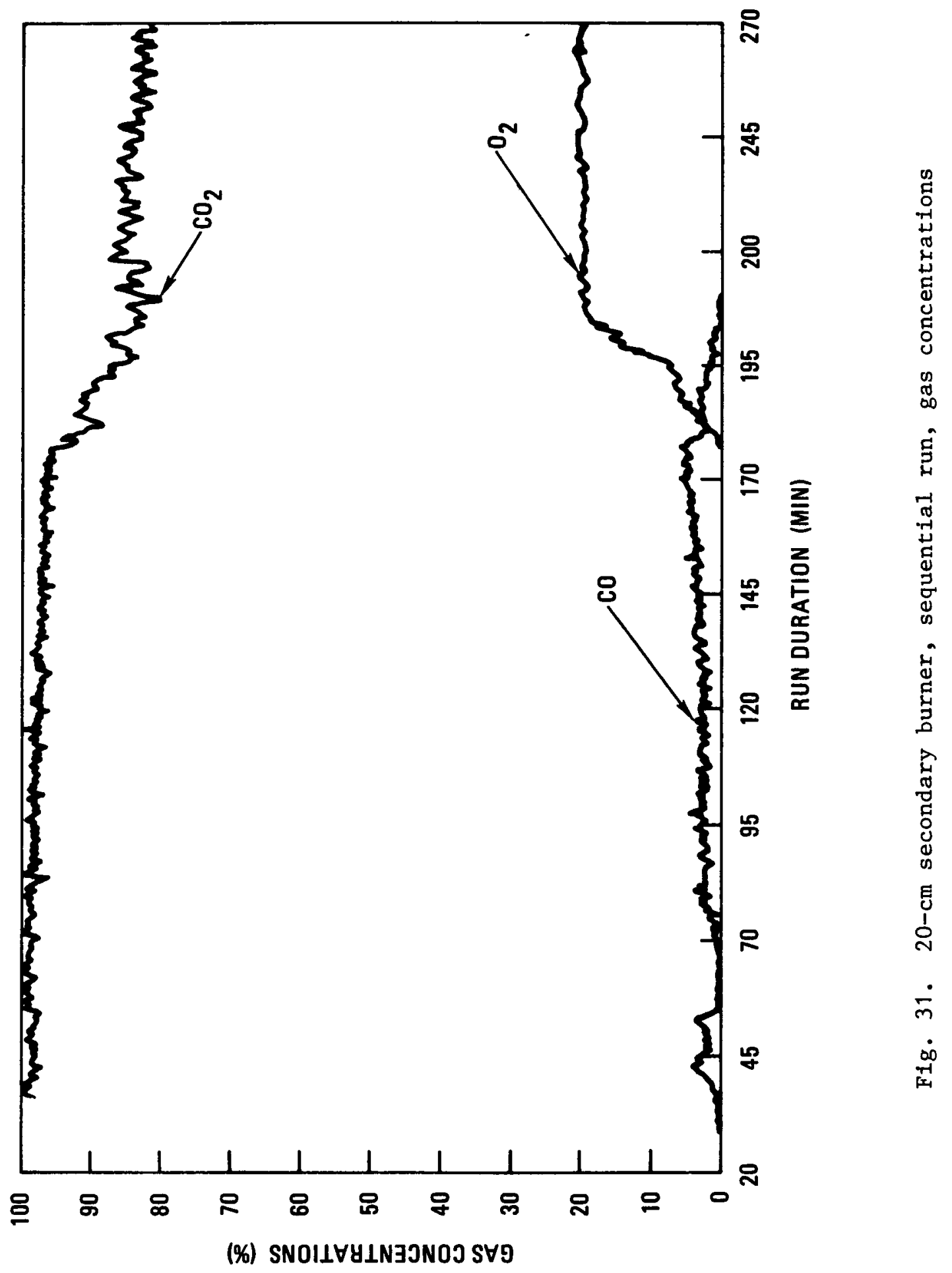


was followed by a 20-min ramp of $\mathrm{O}_{2}$ to a total of $70 \%$-inlet $\mathrm{O}_{2}$ concentration at a superficial velocity of $0.8 \mathrm{~m} / \mathrm{s}$. This level was held constant for $100 \mathrm{~min}$, during which time the modulation of cooling air to the upper vessel kept the fluid bed at $850^{\circ} \mathrm{C}$. Off-gas filters were blown back every $20 \mathrm{~s}$, resulting in a peak pressure drop of $30 \mathrm{~cm}\left(12\right.$ in.) $\mathrm{H}_{2} \mathrm{O}$.

off-gas oxygen breakthrough initiated the final bed burnout period in which inlet $\mathrm{O}_{2}$ rate was gradually reduced to keep the off-gas at less than $20 \%$ oxygen. When combustion rates dropped sufficiently that the bed temperature $\mathrm{fell}$ below $830^{\circ} \mathrm{C}$, the induction heater reactivated to keep the bed at $800^{\circ} \mathrm{C}$ minimum by holding the burner wall at $900^{\circ} \mathrm{C}$. In the final $20 \mathrm{~min}$ of the run, the total gas flow was reduced to $0.45 \mathrm{~m} / \mathrm{s}$ to allow any residual carbon from the filter chamber to reenter the bed and be oxidized.

\subsubsection{Product Material}

Product was cooled to $100^{\circ} \mathrm{C}$ and pneumatically transported to the product bunker as it passed out of the burner through the opened product removal valve. It weighed $32.2 \mathrm{~kg}$ and contained $0.2 \mathrm{wt} \%$ carbon and less than 0.5 wt \% unbroken fuel particles. Product size distribution is shown in Fig. 27.

\subsubsection{Secondary Burner Removal System}

The secondary burner removal system and its BISO transport leg were utilized during the sequential tests. Classified fertile particles were transferred from the fertile product hopper to the secondary burner product hopper at an average gas velocity of $17.5 \mathrm{~m} / \mathrm{s}$ and a feed rate of $0.22 \mathrm{~kg} / \mathrm{s}$. The system pressure drop observations did not correlate as closely as with other systems due to the more complex piping configuration. (The conveying line contains lengths of two different tubing i.d., and a $Y$ junction and diverter valve, both with rough inside surfaces.) The pressure drop results are shown on Fig. 27. 
Secondary burner product was transferred to the secondary burner product hopper by cycling the burner outlet valve to prevent system overload. The $5-\mathrm{cm}(2-\mathrm{in.})$ conveying line has been removed since the sequential operation and a $10-\mathrm{cm}$ (4-in.) line is being installed. An additional transport blower has been installed in parallel with the present secondary burner removal system blower to provide the additional system capacity to handle the full burner feed rate. 


\section{RESULTS}

\subsection{OVERALL MATERIAL MASS BALANCE}

In order to get a complete determination of the material balance of the fuel element components in the operation, the amount and composition of streams entering and leaving each system were measured. This required the determination of the quantity and an analysis of each stream. Samples were taken throughout sequential operations so they could be analyzed at a later time. The analysis consisted of burnback, where samples were weighed, placed in ovens for a given period of time, removed, and then reweighed. While in the oven, the graphite was burned off, and a weight percent graphite determined by the before and after weights. These samples were then leached for percent uranium and thorium.

The start of the sequential pilot plant operations was the crushing of 20 fuel blocks. These blocks had a combined weight of $2448.8 \mathrm{~kg}$ (Table 12).

The rods in each block contain:

$$
\begin{aligned}
& 15.5265 \mathrm{~g} \text { BISO particles } \\
& 4.5168 \mathrm{~g} \text { WAR particles } \\
& \frac{8.1867}{28.2300} \mathrm{~g} \text { matrix and shim }
\end{aligned}
$$

Each block contains 1566 rods, with 20 fuel elements used during sequential operations: 
TABLE 12

FINES ANALYSIS

\begin{tabular}{|c|c|c|c|c|c|c|c|}
\hline $\begin{array}{c}\text { Sample } \\
\text { Description } \\
\text { and Weight } \\
(\mathrm{g})\end{array}$ & $\begin{array}{l}\text { Weight-In } \\
(g)\end{array}$ & $\begin{array}{c}\text { Weight-Out } \\
\text { (g) }\end{array}$ & $\begin{array}{c}\text { Non-Burnable } \\
(\%)\end{array}$ & $\begin{array}{c}\mathrm{Th} \\
\text { Sample } \\
(\mathrm{mg} / \mathrm{g})\end{array}$ & $\begin{array}{c}\mathrm{U} \\
\text { Sample } \\
(\mathrm{mg} / \mathrm{g})\end{array}$ & $\begin{array}{l}\text { Th } \\
(\mathrm{g})\end{array}$ & $\begin{array}{l}U \\
(g)\end{array}$ \\
\hline $\begin{array}{l}\text { No. }{ }^{1} \\
1736\end{array}$ & 52.60 & 0.75 & 1.42 & 236.0 & 168.0 & 5.842 & 4.158 \\
\hline $\begin{array}{l}\text { No. } 2 \\
2115\end{array}$ & 44.75 & 0.50 & 1.12 & 217.0 & 141.0 & 5.128 & 3.332 \\
\hline $\begin{array}{l}\text { No. }{ }^{3} \\
2238\end{array}$ & 34.80 & 2.00 & 5.75 & 132.0 & 137.0 & 16.980 & 17.620 \\
\hline $\begin{array}{l}\text { No. }{ }^{4} \\
1556\end{array}$ & 38.60 & 0.60 & 1.55 & 220.0 & 118.0 & 5.321 & 2.854 \\
\hline $\begin{array}{l}\text { No. } 5 \\
1287\end{array}$ & 39.00 & 2.70 & 6.92 & 122.0 & 136.0 & 10.870 & 12.120 \\
\hline 1305 & 39.40 & 4.00 & 10.15 & 98.3 & 212.0 & 13.020 & 28.090 \\
\hline $\begin{array}{l}\text { No. } 7 \\
1279\end{array}$ & 36.60 & 0.70 & 1.91 & 231.0 & 93.4 & 5.651 & 2.285 \\
\hline $\begin{array}{l}\text { No. }{ }^{8} \\
1404^{8}\end{array}$ & 40.20 & 0.95 & 2.36 & 235.0 & 70.0 & 7.797 & 2.323 \\
\hline $\begin{array}{l}\text { No. } 9 \\
1094\end{array}$ & 40.20 & 6.25 & 15.55 & 85.1 & 154.0 & 14.470 & 26.190 \\
\hline $\begin{array}{l}\text { No. } 10 \\
1620\end{array}$ & 37.00 & 1.05 & 2.84 & 186.0 & 92.3 & 8.551 & 4.243 \\
\hline $\begin{array}{l}\text { No. } 11 \\
1497\end{array}$ & 36.10 & 1.65 & 4.57 & 150.0 & 174.0 & 10.260 & 11.910 \\
\hline $\begin{array}{l}\text { No. } 12 \\
6882\end{array}$ & 44.70 & 8.90 & 19.91 & 70.8 & 172.0 & 97.010 & 235.680 \\
\hline $\begin{array}{l}\text { No. } 13 \\
787\end{array}$ & 42.40 & 7.80 & 18.39 & 61.9 & 143.0 & 89.720 & 207.260 \\
\hline 318.92 & & & & & Total & 290.620 & 557.990 \\
\hline
\end{tabular}


$4.5168 \mathrm{~g}$ TRJ.SO $/ \mathrm{rod}, 1566 \mathrm{rod} / \mathrm{block}, 20$ blocks $=141.466 \mathrm{~kg}$ TRISO

$15.5265 \mathrm{~g}$ BISO $/ \mathrm{rod}, 1566 \mathrm{rod} / \mathrm{block}, 20 \mathrm{blocks}=486.289 \mathrm{~kg}$ BISO

After the carbon is burned off, $62 \%$ BISO and $75 \%$ TRISO particle remains :

$$
\begin{aligned}
& 62 \% \text { of } 486.29 \mathrm{~kg} \text { BISO }=301.493 \mathrm{~kg} \text { BISO } \\
& 75 \% \text { of } 141.46 \mathrm{~kg} \text { TRISO }=106.095 \mathrm{~kg} \text { TRISO }
\end{aligned}
$$

These $407.588 \mathrm{~kg}$ particles, plus the graphite were transported through the pneumatic transport system to the crushed product bunker, and later to the primary feed bunker. Samples were taken of the crushed blocks immediately after leaving the UNIFRAME, and again immediately after leaving the crushed product bunker.

The product from the primary burner was removed in four separate quantities (see Fig. 32): (1) final bed, (2) initial transfer, (3) plenum, and (4) fines.

Thirteen samples of the fines were taken and sent to the laboratory for chemical analysis (Table 13). The milligrams of thorium and uranium were reported per gram sample of the burned back fines. As expected, the percent uranium and thorium in the fines was low. Of the $31.892 \mathrm{~kg}$ of fines removed, overall there were $290.62 \mathrm{~g}$ thorium $(0.81 \%)$ and $557.99 \mathrm{~g}$ uranium (1.5\%).

The initial transfer was transported from the primary burner to the primary burner product bunker, and then on to system. A temporary blockage in the primary burner outlet suspended further use of the transport system and the remaining product was conveyed by other means. This first batch of $113.7 \mathrm{~kg}$ was used as the feed for the first classifier test.

The plenum material (th. material which had fallen through the gas distributor holes into the plenum), along with $37.5 \mathrm{~kg}$ of the initial bed 


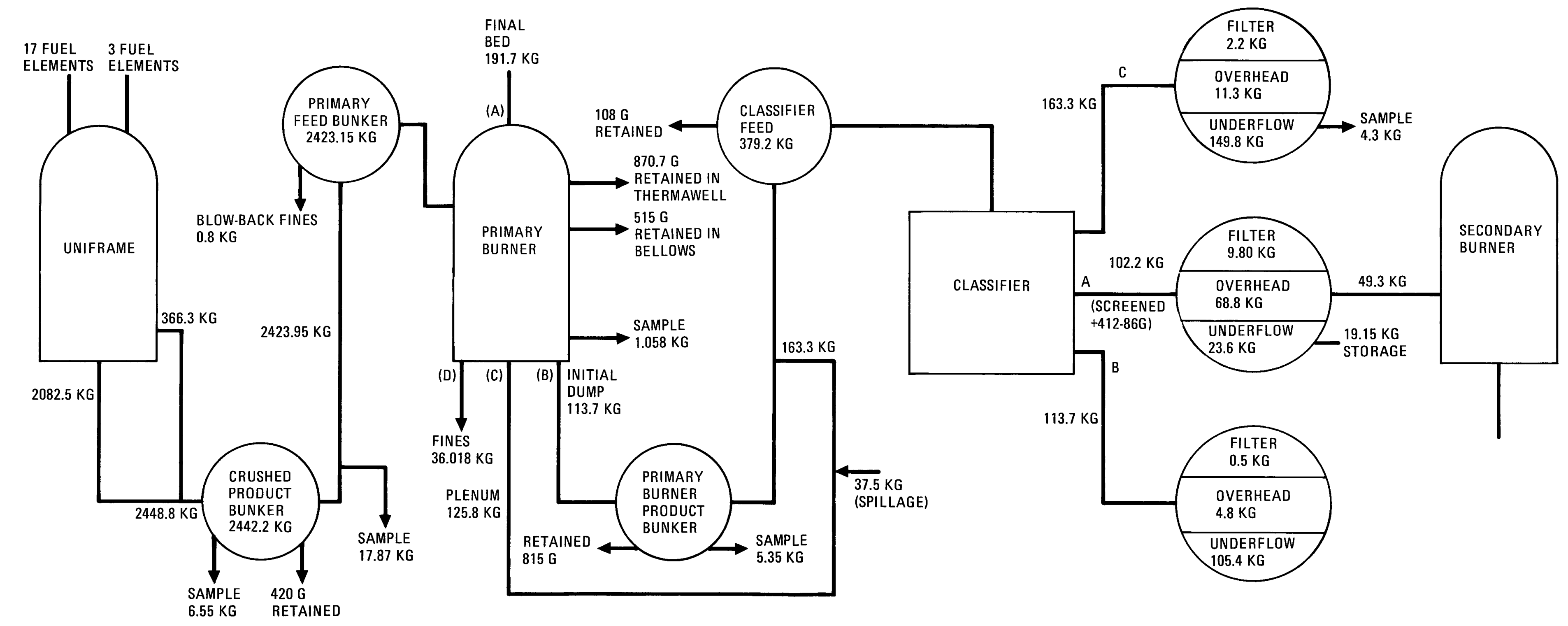

Fig. 32. Flow diagram 
TABLE 13

CHEMICAL ANALYSIS ON PRODUCTS AFTER CLASSIFICATION

\begin{tabular}{|c|c|c|c|c|c|}
\hline & $\begin{array}{c}\mathrm{C} \\
(\%)\end{array}$ & $\begin{array}{c}\text { Th } \\
(\text { wt \%) }\end{array}$ & $\begin{array}{c}U \\
(w t \%)\end{array}$ & $\begin{array}{l}\mathrm{ThO}_{2} \\
(\mathrm{wt} \%)\end{array}$ & $\begin{array}{l}\text { WAR } \\
(\text { wt \%) }\end{array}$ \\
\hline \multicolumn{6}{|c|}{$\begin{array}{l}\text { Initial Bed Removal } \\
(113.7 \mathrm{~kg})\end{array}$} \\
\hline $4.8 \mathrm{~kg}$ overhead & 3.0 & 51.3 & 3.3 & 58.4 & 18.3 \\
\hline $108.4 \mathrm{~kg}$ underflow & 1.0 & 87.9 & 1.1 & 100.0 & 6.0 \\
\hline $0.5 \mathrm{~kg}$ filter chamber & 8.2 & 12.9 & 12.7 & 14.7 & 70.6 \\
\hline \multicolumn{6}{|c|}{$\begin{array}{l}\text { Plenum Materials (with some initial dump) } \\
(167.6 \mathrm{~kg})\end{array}$} \\
\hline $11.3 \mathrm{~kg}$ overhead & 14.5 & 26.2 & 10.0 & 29.8 & 55.6 \\
\hline $\begin{array}{l}149.8 \mathrm{~kg} \text { underflow } \\
(+4.3 \text { sample) }\end{array}$ & 1.0 & 84.2 & 0.7 & 95.8 & 3.9 \\
\hline $2.2 \mathrm{~kg}$ filter chamber & 41.0 & 10.9 & 10.7 & 12.4 & 59.4 \\
\hline \multicolumn{6}{|c|}{$\begin{array}{c}\text { Final Bed Removal } \\
(102.2 \mathrm{~kg})\end{array}$} \\
\hline 69.0 overhead & 7.2 & 3.0 & 15.7 & 3.4 & 87.2 \\
\hline $24.1 \mathrm{~kg}$ underflow & 18.8 & 80.0 & 0.67 & 91.0 & 3.7 \\
\hline $9.1 \mathrm{~kg}$ filter chamber & 15.5 & 0.91 & 15.9 & 1.0 & 88.3 \\
\hline
\end{tabular}


dump material (which had spilled as a result of the transport line blockage), was taken directly to the classifier feed hopper. This $163.3 \mathrm{~kg}$ material constituted the feed for the second classification batch.

The final bed, which remained in the burner until after shutdown, was vacuumed out the top. This material $(191.7 \mathrm{~kg})$ was screened prior to classification. This was done to remove any remaining large chunks of graphite or fines. The portion classified was $102.2 \mathrm{~kg}$ of +412 to -869 screen size (Table 13).

Classification resulted in the separation of material into three parts: (1) the overhead, (2) underflow, and (3) the filter chamber. Samples were taken of each stream and analyzed for thorium and uranium content.

From the screened final bed material, $49.3 \mathrm{~kg}$ were taken from the overhead section. This material (basically TRISO-coated WAR particles with $9 \%$ graphite) was further burned in the secondary burner.

Table 14 shows the total thorium, ThO ${ }_{2}$, uranium and WAR particles. Upon completion of the material balance, $104.38 \mathrm{~kg}$ WAR particles and $298.23 \mathrm{~kg} \mathrm{ThO} \mathrm{T}_{2}$ were accounted for. This represents $98.3 \%$ of WAR particles and $98.9 \%$ of $\mathrm{ThO}_{2}$.

\subsection{OVERALL PARTICLE BREAKAGE AND CROSSOVER}

The particle breakage and overall crossover figures are given in Table 15. It can be seen that the crossover is less severe than the breakage. This probably has two causes: (1) BISO fragments with terminal velocities larger than TRISO particles will not cross over, and (2) TRISO particles which are cracked appear broken in analyses, but behave norma1ly in the classifier. 
TABLE 14

MATERIAL BALANCE TOTALS

\begin{tabular}{l|r|r|r|r}
\hline & \multicolumn{1}{|c|}{$\begin{array}{c}\text { Th } \\
(\mathrm{kg})\end{array}$} & \multicolumn{1}{c|}{$\begin{array}{c}\mathrm{ThO} 2 \\
(\mathrm{~kg})\end{array}$} & \multicolumn{1}{c|}{$\begin{array}{c}\mathrm{U} \\
(\mathrm{kg})\end{array}$} & \multicolumn{1}{c}{$\begin{array}{c}\text { WAR } \\
(\mathrm{kg})\end{array}$} \\
\hline Initial dump & 96.7300 & 110.0880 & 1.3700 & 7.6140 \\
Plenum & 131.1300 & 149.2290 & 2.1800 & 12.0930 \\
Final bed, after screening & 17.6500 & 20.0890 & 11.4000 & 63.3490 \\
Fines, hoppers & 0.0186 & 0.0213 & 0.0443 & 2.4600 \\
\multicolumn{1}{c|}{ samples } & 0.0104 & 0.0118 & 0.0115 & 0.0639 \\
Final bed screened out & 9.6300 & 10.9600 & 1.7100 & 9.5000 \\
Samples, crushed product bunker & 3.5900 & 4.0800 & 1.0300 & 5.7200 \\
Samples, UNIFRAME & 0.7308 & 0.8316 & 0.0434 & 0.2400 \\
Sample, primary feed bunker & 0.1200 & 0.1365 & 0.0300 & 0.1660 \\
Samples, primary product bunker & 0.5052 & 0.5749 & 0.3535 & 1.9630 \\
Retained material & 1.9300 & 2.2000 & 0.2182 & 1.2110 \\
\hline Total & 262.0500 & 298.2300 & 18.3900 & 104.3800 \\
\hline
\end{tabular}


TABLE 15

OVERALL PARTICLE BREAKAGE AND CROSSOVER

\begin{tabular}{l|l|c}
\hline $\begin{array}{c}\text { Sequence of } \\
\text { Operation }\end{array}$ & Particle & $\begin{array}{c}\text { Breakage } \\
(\%)\end{array}$ \\
\hline \multirow{2}{*}{ UNIFRAME } & BISO & 0.8 \\
Burner feed & BISO & 2.6 \\
& TRISO & 0.9 \\
Overal1 & BISO & 7.3 \\
& TRISO & 6.6 \\
Crossover & BISO $\rightarrow$ TRISO & 22.5 \\
& TRISO $\rightarrow$ BISO & 15.4 \\
\hline
\end{tabular}


This initial sequential operation demonstrated the feasibility of the process. Reduction in particle breakage, and hence crossover, can be achieved in a number of ways: (1) better control of crusher product feed rate to conveying systems at lower gas velocities, (2) reduction of plenum drainage, and (3) implementation of gravity fines recycle.

The next sequential operation, aimed at establishing production rates and product specifications, will demonstrate these improvements. 
0

. 
REFERENCES

1. Heath, C. A., and M. E. Spaeth, "Reprocessing Development for HTGR Fuels," ERDA Repört GA-A13279, General Atomic Company, February 15, 1975.

2. "The General Atomic Reprocessing Pilot Plant: Description and Results of Initial Testing," DOE Report GA-A14642, General Atomic Company, Decemfer 1977.

3. Strand, J. B., J. W. Baer, and E. J. Cook, "UNIFRAME Interim Design Report," DOE Report GA-A14645, General Atomic Company, December 1977.

4. Young, D. T., "Fluidized Combustion of Beds of Large, Dense Particles in Reprocessing HTGR Fuel, ERDA Report GA-A14327, General Atomic Company, March 1977.

5. Rode, J. S., "Process Control of an HTGR Fuel Reprocessing Cold Pilot Plant," ERDA Report GA-A14101, General Atomic Company, October 1976.

6. Engineering Equipment Users' Association (EEUA), Handbook No. 15, "Pneumatic Handling of Powdered Materials Including Fluidization," Constable and Company, Ltd., London, 1963.

7. Jenike, A. W., "Storage and Flow of Solids," Bulletin 123 of the Utah Engineering Experiment Station, University of Utah, 1967. 